\title{
Bibliografia historii wychowania, szkolnictwa i myśli pedagogicznej w Polsce za rok 2001 ( $\mathrm{z}$ uzupełnieniami za rok 2000)
}

\section{WSTEP}

Bibliografia rejestruje druki zwarte, artykuły z czasopism i prac zbiorowych. Obejmuje pozycje wydane w 2001 r. oraz te z 2000 r., które nie znalazły się w bibliografii za rok 2000, opublikowanej w z. $1 / 2$,Biuletynu Historii Wychowania" z 2002 r. Bibliografia ma układ rzeczowy według podanego niżej schematu.

I. Opracowania ogólne. Bibliografie

II. Rozwój oświaty, wychowania i myśli pedagogicznej

1. Opracowania ogólne

2. Okres do 1795 roku

3. Okres $1795-1918$

4. Okres $1918-1939$

5. Okres $1939-1945$

6. Okres $1945-1989$

7. Okres 1989-2000

8. Oświata polonijna

III. Dzieje szkół różnych stopni

1. Szkoły podstawowe i zakłady wychowawcze

2. Szkoły średnie ogólnokształcące

3. Szkoły zawodowe

4. Zakłady kształcenia nauczycieli (z wyjątkiem szkół wyższych)

5. Szkoły wyższe

IV. Teoretycy wychowania i działacze oświatowi

1. Zbiory życiorysów

2. Poszczególne biografie

V. Dzieje oświaty pozaszkolnej

1. Oświata dorosłych

2. Biblioteki

VI. Dzieje ruchu nauczycielskiego

1. Opracowania ogólne i monografie

2. Pamiętniki nauczycieli

VII. Z życia i działalności organizacji młodzieżowych 


\title{
WYKAZ SKRÓTÓW CZASOPISM I WYDAWNICTW CIĄGŁYCH
}

\author{
Acta Univ. N. Copernici - Acta Universitatis Nicolai Copernici \\ Acta Univ. Lodziensis - Acta Universitatis Lodziensis \\ Acta Univ. Wratislaviensis - Acta Universitatis Wratislaviensis \\ Annales Acad. Paedagog. Cracoviensis - Annales Academiae Paedagogicae Cracoviensis \\ Archiwista Pol. - Archiwista Polski \\ Archiwum Hist. Filoz. i Myśli Społ. - Archiwum Historii Filozofii i Myśli Społecznej \\ Archiwum Hist. i Filoz. Med. - Archiwum Historii i Filozofii Medycyny \\ Ateneum Kapł. - Ateneum Kapłańskie \\ Białoruskie Zesz. Hist. - Białoruskie Zeszyty Historyczne \\ Biul. Hist. - Biuletyn Historyczny (Muzeum Marynarki Wojennej) \\ Biul. Hist. Pogranicza - Biuletyn Historii Pogranicza \\ Biul. Inst. Pamięci Nar. - Biuletyn Instytutu Pamięci Narodowej \\ Czasop. Prawno-Hist. - Czasopismo Prawno-Historyczne \\ Częstochowskie Studia Teol. - Częstochowskie Studia Teologiczne \\ Komunikaty Mazur.-Warm. - Komunikaty Mazursko-Warmińskie \\ Krakowski Roczn. Archiw. - Krakowski Rocznik Archiwalny \\ Kwart. Hist. Nauki i Techn. - Kwartalnik Historii Nauki i Techniki \\ Kwart. Hist. Żydów - Kwartalnik Historii Żydów \\ Lubelski Roczn. Pedagog. - Lubelski Rocznik Pedagogiczny \\ Mater. Zachodniopomorskie - Materiały Zachodniopomorskie \\ Mazowieckie Studia Humanist. - Mazowieckie Studia Humanistyczne \\ Nadwarciański Roczn. Hist.-Archiw. - Nadwarciański Rocznik Historyezno-Archiwalny \\ Nauka Pol. - Jej Potrzeby, Organizacja i Rozwój - Nauka Polska - Jej Potrzeby, Organizacja i Rozwój \\ Opolskie Roczniki Ekonom. - Opolskie Roczniki Ekonomiczne \\ Pamiętn. Bibl. Kómickiej - Pamiętnik Biblioteki Kómickiej \\ Pamiętn. Cieszyński - Pamiętnik Cieszyński \\ Pamiętn. Tow. Miłośn. Ziemi Kościańskiej - Pamiętnik Towarzystwa Miłośników Ziemi Kościańskiej \\ Prace Hist.-Archiw. - Prace Historyczno-Archiwalne \\ Przegl. Bibliot. - Przeglad Biblioteczny \\ Przegl. Hist. - Przegląd Historyczny \\ Przegl. Hist.-Ośw. - Przegląd Historyczno-Oświatowy \\ Przegl. Orientalist. - Przegląd Orientalistyczny \\ Przegl. Polonijny - Przegląd Polonijny \\ Przegl. Prawosławny - Przeglad Prawosławny \\ Przegl. Zachodniopomorski - Przegląd Zachodniopomorski \\ Roczn. Bibl. Nauk. PAU i PAN w Krakowie - Rocznik Biblioteki Naukowej PAU i PAN w Krakowie \\ Roczn. Bocheński - Rocznik Bocheński \\ Roczn. Gdański - Rocznik Gdański \\ Roczn. Grudziądzki - Rocznik Grudziądzki \\ Roczn. Hist. Prasy Pol. - Rocznik Historii Prasy Polskiej \\ Roczn. Jeleniogórski - Rocznik Jeleniogórski \\ Roczn. Komisji Nauk Pedagog. - Rocznik Komisji Nauk Pedagogicznych \\ Roczn. Krakowski - Rocznik Krakowski \\ Roczn. Lubuski - Rocznik Lubuski \\ Roczn. Łódzki - Rocznik Łódzki \\ Roczn. Mazurski - Rocznik Mazurski \\ Roczn. Międzyrzecki - Rocznik Międzyrzecki
}


Roczn. Muzeum Nar. Rolnictwa w Szreniawie - Rocznik Muzeum Narodowego Rolnictwa w Szreniawie

Roczn. Muzeum w Gliwicach - Rocznik Muzeum w Gliwicach

Roczn. Sądecki - Rocznik Sąecki

Roczn. Świdnicki - Rocznik Świdnicki

Roczn. Świętokrzyski - Rocznik Świętokrzyski

Roczn. Toruński - Rocznik Toruński

Roczn. Warszawski - Rocznik Warszawski

Roczniki Dziejów Społ. i Gosp. - Rocznikj Dziejów Społecznych i Gospodarczych

Roczniki Bibliot. - Roczniki Biblioteczne

Roczniki Nauk. AWF w Warszawie - Roczniki Naukowe AWF w Warszawie

Roczniki Teolog. - Roczniki Teologiczne

Studia z Dziejów Rosji i Europy Środk.-Wsch. - Studia z Dziejów Rosji i Europy Środkowo-Wschodniej

Śląski Kwart. Hist. Sobótka - Śląski Kwartalnik Historyczny Sobótka

Wiadom. Hist. - Wiadomości Historyczne

Włoszczowskie Zesz. Hist. - Włoszczowskie Zeszyty Historyczne

Zagadn. Naukozn. - Zagadnienia Naukoznawstwa

Zapiski Hist. - Zapiski Historyczne

Zesz. Chorzowskie - Zeszyty Chorzowskie

Zesz. Hist. - Zeszyty Historyczne

Zesz. Hist.-Teol. - Zeszyty Historyczno-Teologiczne

Zesz. Hist. WiN-u - Zeszyty Historyczne WiN-u

Zesz. Muzeum Pojezierza Łęczyńsko-Włodawskiego - Zeszyty Muzeum Pojezierza Łęczyńsko-Włodawskiego

Zesz. Nauk. WSHE - Zeszyty Naukowe WSHE (Włocławek)

\section{OPRACOWANIA OGÓLNE. BIBLIOGRAFIE}

1. BIBLIOGRAFIA Ryszarda Wroczyńskiego [1909-1987]. Oprac. Wiesław Theiss, Urszula Pawłowicz. Warszawa 200I Żak ss. 68.

2. JEDRRZEJEC Danuta: Przegląd publikacji poświęconych wychowaniu przedszkolnemu w powojennym czterdziestołeciu. Przegl. Hist.-Ośw. R. 44: 2001 nr 3/4 s. $143-147$.

3. HINZ Janusz: Bibliografia toruńskich druków szkolnych tzw. Thorunensii scholasticae w zbiorach dawnej Biblioteki Gimnazjum Akademickiego w Toruniu, obecnie w Książnicy Miejskiej w Toruniu. Grudziądz 2001 Bibl. Zespołu Szkół Medycznych ss. 161

XVI-XVIII w.

4. NIPARKO Romuald: „Miesięcznik Katechetyczny i Wychowawczy” 1911 - 1939. Bibliografia zawartości. Poznań 2000 UAM WT ss. 219, nlb. 1, il., sum. Uniw. im. A. Mickiewicza w Poznaniu. Wydz. Teol. Studia i Materiały. [T.] 36.

5. PRUSZYŃSKA Agnieszka: Międzyuniwersytecka Biblioteka Medyczna (BIUM) w Paryżu. Zbiór polskich rozpraw doktorskich. Archiwum Hist. i Filoz. Med. T. 64: 2001 z. 1 s. 49-60, sum.

6. RULKA Kazimierz: Wykaz niepublikowanych prac magisterskich doktorskich przechowywanych w Bibliotece Wyższego Seminarium Duchownego we Włocławku. Studia Włoclawskie. T. 4: 2001 s. $405-432$.

$\mathrm{Z}$ lat $1981-2001$. 
7. SMOŁALSKI Antoni: Polska historiografia pedeutologiczna (wersja podstawowa). Przegl. Hist.-Ośw. R. 44: 2001 nr 3/4 s. 5-23.

8. WYKAZ prac magisterskich powstałych w Mazowieckiej Wyższej Szkole Humanistyczno-Pedagogicznej pod kierunkiem prof. Tadeusza Rawskiego w latach 1995 - 2000. W: Z dziejów wojen i wojskowości. Księga pamiątkowa poświęcona prof. dr. hab. Tadeuszowi Rawskiemu z okazji 55-lecia rozpoczęcia pracy naukowej. Pod red. nauk. Piotra Matusaka. Lowicz 2001 s. 232-234.

\section{ROZWÓJ OŚWIATY, WYCHOWANIA I MYŚLI PEDAGOGICZNEJ}

\section{Opracowania ogólne}

9. BANACH Czesław: Blaski i cienie polskiej edukacji w XX wieku. Przegl. Hist.-Ośw. R. 44: 2001 nr $1 / 2$ s. $5-14$.

10. BOGUSZEWSKA Anna: Miejsce przedmiotu „,rysunek” w kształceniu ogólnym w pierwszej połowie XX wieku. Przegl. Hist.-Ośw. R. 44: 2001 nr 1/2 s. 65-81.

11. CIEPIELów dawniej i dziś. Pod red. Henryka Bednarczyka i Heleny Kowalskiej-Kutery. Sycyna 2001 Stow. Oświatowe Sycyna; Wyższa Szkoła Pedagog. ZNP w Warszawie ss. 232, nlb. 4, tabl. 16, il. Biblioteka Sycyńska. T. 5.

Z treści: Hyc Danuta: Przedszkole s. 93 - 98; Garganisz Barbara, Kowalska-Kutera H., Giemza Iwona: Publiczna Szkoła Podstawowa s. 99-153; Giemza Elżbieta: Gimnazjum s. 154-157.

12. DYBIEC Julian: Recepcja idei pedagogicznych w Polsce. W: Recepcja w Polsce nowych kierunków i teorii naukowych. Pod red. Adama Strzałkowskiego. Kraków 2001 s. 195-202.

13. DZIEJE nauczania medycyny na ziemiach polskich. Pod red. Mariusza M. Żydowo. Kraków 2001 PAU ss. 261, nlb. 7, tabl. 30, il., mapy. Rozprawy Wydziału Lekarskiego. T. 1.

Treśc: Żydowo M. M.: Wstęp s. 7 -12; Kaliciński Andrzej: Dzieje nauczania medycyny na Podlasiu s. 13-23; Domaniewski Jan: Dzjeje nauczania medycyny w Bydgoszczy s. 25 - 34; Żydowo M. M.: Dzieje nauczania medycyny w Gdańsku s. 35-50; Puzio Alfred, Szczygieł Sławomir, Kempa Maria: Dzieje nauczania medycyny na Gómym Ślasku s. 51-65; Gajda Zdzisław: Dzieje nauczania medycyny w Krakowie s. $67-88$; Borkowski Tomasz: Historia nauczania medycyny na Lubelszczyźnie s. 89-96; Wojtkiewicz-Rok Wanda: Tradycje akademickiego nauczania medycyny we Lwowie s. 97 - 121; Greger Janusz: Rozwój medycyny akademickiej w Łodzi s. 123 - 129; Karoń Halina: Dzieje nauczania medycyny w Poznaniu s. 131 - 142; Machoy Zygmunt: Historia nauczania medycyny w Szczecinie s. 143 - 155; Sródka Andrzej, Stembrowicz Wiesław, Zabłotniak Ryszard: Dzieje nauczania medycyny w Warszawie s. 157 -187; Stanek Aleksander, Śledziński Zbigniew: Dzieje nauczania medycyny w Wilnie s. 189-220; Heimrath Tadeusz: Nauczanie medycyny we Wrocławiu s. 221-240.

14. DZIEJE Rzeszowa. T. 3: Rzeszów w okresie międzywojennym i okupacji (1918 - 1944). Pod red. Feliksa Kiryka. Rzeszów 2001 Urząd Miasta; Libri Ressovienses ss. 1072, tabl. 6, il., sum., Zsfg,, rez.

Z treści: Świeboda Józef: Oświata i szkolnictwo s. 173-227.

15. FUDALI Robert: Realizm pedagogiczny w ujęciu J[ana] Wł[adysława] Dawida. Przegl. Hist.-Ośw. R. 44: 2001 nr 1/2 s. $123-127$.

W publikacjach z l. $1912-1927$.

16. FURMANOWSKA Mirosława: Historia wychowania seksualnego $w$ Polsce $w$ latach 1945-2000. Przegl. Hist.-Ośw. R. 44: 2001 nr 3/4 s. $105-108$.

17. GAWLIK Stanisław: Sierocińce w działalności Zgromadzenia Małych Sióstr Niepokalanego Serca Maryi. Studia Teol.-Hist. Ślaska Opolskiego. T. 21: 2001 s. 353-362, Zsfg.

Lata 1888 - 1939 na terenach Białorusi, Lotwy, Rosji (Petersburg) i Polski. 
18. GERLIC Henryk: Dzieje szkolnictwa w Gliwicach ze szczególnym uwzględnieniem wkładu Kościoła. Roczn. Muzeum w Gliwicach. T. 16: 2001 s. 275-285, sum., Zsfg. XIII - XX w.

19. GOŁAŃCZ. Z dziejów miasta i regionu. Praca zbior. pod red. Andrzeja Wędzkiego. Gołańcz 2001 Tow. Miłośn. Ziemi Golanieckiej; Zarząd Miasta i Gminy ss. 266, il., mapy.

Z treści: Wieczorek Andrzej: Oświata [w 1. 1918-1939] s. 129-136;Wieczorek A., Osuch Wojciech: Oświata i kultura [w 1. 1945-1989] s. 169-191.

20. GOMOLISZEK Joanna: Toruńskie czasopisma studenckie w latach 1945-1995. Toruń 2001 Wydaw. Adam Marszałek ss. 154, tabl. 25, il.

21. GRABOWSKI Stanisław: Na przyszły pożytek. Z dziejów polskiej prasy dla dzieci 1824 - 1939. Pułtusk 2001 Wyższa Szkoła Humanist. ss. 267, il.

22. GRADKOWSKI Henryk: Mickiewicz w polskiej szkole XIX i pierwszej polowie XX wieku. Strategia lektury i style odbioru. Jelenia Góra 2001 Kolegium Karkonoskie. Państ. Wyższa Szkoła Zawodowa ss. 278, il.

23. HELLWIG Jan: Dzjeje historii wychowania w Polsce i jej twórcy (próba zarysu historycznego). Poznań 2001 Eruditus ss. 261, nlb. 1.

24. HOCHLEITNER Janusz: Szkolnictwo elementarne na Warmii w dobie potrydenckiej reformy katolickiej (1565-1623). Echa Przesztości. [T.] 1: 2000 s. 41-62.

25. JÓŹWIAK Sławomir: Materiały do dziejów oświaty w gminie Bieliny (1823-1952). Roczn. Świętokrzyski. Ser. A: Nauki Humanist. T. 26: 1999 [druk.:] 2001 s. 117-125.

26. KARDYŚ Piotr: Rola Wiślicy w okresie plemiennym i poczatków państwa polskiego w świetle podręczników historii po 1958 r. Przegl. Hist.-Ośw. R. 44: 2001 nr 3/4 s. $41-48$.

27. KEDZIERZYN-KOŹLE. Monografia miasta. Praca zbior. pod red. nauk. Edwarda Nycza i Stanisława Senfta. Opole 2001 Wydaw. IŚ ss. 460, nlb. 3, tabl. 12, il., mapy. Państ. Inst. Nauk. Inst. Śląski w Opolu.

Z ıreści: Papis Dorota: Szkolnictwo podstawowe i średnie w Kędzierzynie-Koźlu [lata 1918 - 1945] s. 397 - 415.

28. KONGRESY i zjazdy pedagogiczne w Polsce w XX wieku. Pod red. Alicji Kicowskiej. Toruń 2001 Wydaw. Uniw. M. Kopernika ss. 351, il.

Treść: Kwieciński Zbigniew: Pedagogiła wobec kryzysu i przelomu. Funkcje ogólnopolskich zjazdów pedagogicznych w latach dziewięćdziesiatych s. 9-12; Płocha Halina: Poczatki odrodzonego szkolnictwa polskiego - Sejm Nauczycielski 14 - 17.04 .1919 r. s. 15 - 26; Gajdamowicz Halina: Cele wychowania na kongresach i zjazdach pedagogicznych w II Rzeczypospolitej s. 27-38; Magiera Elżbieta: Stanowisko kongresów pedagogicznych Drugiej Rzeczypospolitej wobec wychowania państwowego s. $39-54$; Jalmużna Tadeusz: Organizacje młodzieżowe przedmiotem zainteresowań kongresów pedagogicznych w latach międzywojennych s. 55-62; Michalski Grzegorz: "Tydzień Szkoły Pracy" przykładem zjazdowej inicjatywy lokalnej w Poznaniu w 1925 r. s. 63 - 71; Moskalik Urszula: Kongres poznański w cieniu Powszechnej Wystawy Krajowej w 1929 roku s. 72 - 79; Koźmian Danuta: III Kongres Pedagogiczny we Lwowie i jego wpływ na kształtowanie ustroju szkolnego oraz tworzenie nowych programów nauczania w Drugiej Rzeczypospolitej s. 80-95; Jakubiak Krzysztof: Problematyka i dorobek zjazdów pedagogów Akcji Katolickiej w II Rzeczypospolitej s. 96-105; Posłuszna Malgorzata: Edukacja zdrowotna w świetle dyskusji i postanowień kongresów pedagogicznych II Rzeczypospolitej s. 106-120; Jamrożek Wiesław: Problematyka opieki nad dzieckiem na kongresach i zjazdach pedagogicznych w Polsce do 1939 roku s. 121-137; Kuczyńska Ewa: Dziecko niepełnosprawne w świetle dyskusji i postanowień kongresów oraz zjazdów pedagogicznych II Rzeczypospolitej s. 138 - 151; Gulczyńska Justyna: Problematyka kształcenia nauczycieli podczas kongresów pedagogicznych II Rzeczypospolitej s. 152 - 157; Walasek Stefania: Pierwszy Zjazd nauczycielstwa pracujacego na Litwie w Wilnie (18-20 sierpnia 1919 r.) s. 158-171; Gąsiorowski Andrzej: I Polski Zjazd Oświatowy w Republice Litewskiej - jego przebieg i cele (Kowno $2-3$ listopada 1923 r.) s. 172-187; Kabzińska Łucja: Udzial polskich pedagogów w Międzynarodowych Kongresach Ligi Nowego Wychowania okresu międzywojennego s. 188-208; Grzes Bolesław: Wizja powojennej oświaty i szkolnictwa w uchwalach Tajnej Organizacji Nauczycielskiej s. 209-231; Kabziński Krzysztof: Rola zjazdów pedagogicznych w kształtowaniu się ustroju szkolnego Polski w latach $1945-1948$ s. 235 - 244; Jankowski Robert: Problemy budowy szkoły polskiej na Pomorzu Zachodnim w pracach Ogólnopolskiego 
Zjazdu Oświatowego w Łodzi w 1945 roku s. 245-253; Wojtowicz Marian W.: Kontrowersje na temat ksztalcenia nauczycieli na Ogólnopolskim Zjeździe Oświatowym w Łodzi w 1945 roku s. 254 - 277; Michalska Iwonna: Nowe zadania nauki w Polsce. Powojenne zjazdy Naukowego Towarzystwa Pedagogicznego (1947-1948) s. 278-288; Hellwig Jan: Wojewódzki Zjazd Oświatowy w Poznaniu w 1957 roku; Kicowska A.: Problemy oświaty rolniczej na zjazdach pedagogicznych w latach 1945-1959 s. 294-305; Malewska Eugenia: Tradycje Międzynarodowych Kolokwiów Pedagogiki Rolniczej s. 306-312; Konarzewski Krzysztof: Trzeci Ogólnopolski Zjazd Pedagogiczny o reformie oświaty s. 313-324; Melosik Zbyszko: Kongresy pedagogiczne lat dziewięćdziesiątych XX wieku - od „pedagogiki zamkniętej” do „pedagogiki pogranicza” s. 325-340; Leppert Roman: Polskie zjazdy pedagogiczne lat dziewięćdziesiąych XX wieku wobec problemu tożsamości jako dyscypliny naukowej s. 341 - 349

29. KSIAZŻKA, biblioteka, szkoła w kulturze Śląska Cieszyńskiego. Materiały z konferencji naukowej, Cieszyn 4 - 5 listopada 1999. Pod red. Janusza Spyry. Cieszyn 2001 Ksiażnica Cieszyńska; Zarzad Gł. Macierzy Ziemi Cieszyńskiej; Społeczny Kom. Budowy Pomnika Ks. Leopolda Jana Szersznika ss. 400 , Zsfg.

Treść: Spyra J., Szelong Krzysztof: Wprowadzenie s. 5-8; Nowak Krzysztof: Stan badań nad dziejami szkolnictwa na Śląsku Cieszyńskim s. 9-26; Gojniczek Wacław, Rusnok Anna: Źródła do badań nad dziejami szkolnictwa na Śląsku Cieszyńskim w zbiorach Archiwum Państwowego w Katowicach Oddział w Cieszynie, Ksiażnicy Cieszyńskiej oraz Biblioteki Tschammera s. 27-49; Štěrbovả Jarmila: Prameny k déjinảm školství v Zemském archivu v Opavě s. 50-58; Szelong Krzysztof: Podróże edukacyjne szlachty cieszyńskiej (do końca XVII w.). Motywy, kierunki, konsekwencje s. 59-115; Gojniczek Wacław: Gimnazjum Ewangelickie w Cieszynie a elity społeczności protestanckiej na Śląsku Cieszyńskim (1709-1781) s. 116-132; Kubacz Adam: Wpływ reform terezjańskich i józefińskich na rozwój szkolnictwa na Śląsku Cieszyńskim s. 133-153; Chromik Grzegorz Marek: Dzieje gimnazjum katolickiego w Cieszynie w świetle pism ks. Leopolda Jana Szersznika [1747-1814] s. 154 - 166; Spyra J.: Główne kierunki rozwoju szkolnictwa na Śląsku Cieszyńskim w XIX w. i na początku XX w. w świetle ustawodawstwa i statystyk s. 167-216; Buława Edward: Formowanie się intelektualnego, światopogladowego i zawodowego oblicza polskiego nauczycielstwa szkól ludowych na Sląsku Cieszyńskim do 80. lat XIX w. s. 217-239; Dawid Łucja: Źródła intelektualnej, światopoglądowej i zawodowej fromacji nauczycielstwa polskiego Ślaska Cieszyńskiego w latach 1888 - 1918. Szkic do portretu zbiorowości s. 240 - 251; Gawrecki Dan: Nèmeckè školy na Tešinsku 1848 - 1918 s. 265 - 283; Spyra J.: Szkolnictwo żydowskie na Śląsku Cieszyńskim i jego rola w procesie asymilacji miejscowej społecznosci żydowskiej (przed 1918 r.) s. 284-312; Kenig Piotr: Zarys dziejów szkolnictwa w Bielsku i Bialej do 1918 r. s. 313 - 331; Bieńkowska Barbara: Edukacyjna rola biblioteki Leopolda J. Szersznika s. 332 - 340; Zeprzałka Hanna: Biblioteki szkolne na Śląsku Cieszyńskim w świetle sprawozdań szkolnych (1850 - 1939) s. 341 - 356; Król Stefan: Sprawozdania i programy szkolne jako źródło do badań nad dziejami szkolnictwa na Śląsku Cieszyńskim s. $357-366$.

30. KSZTAECENIE archiwistów w Polsce na tle porównawczym. Archiwista Pol. R. 6: $2001 \mathrm{nr}$ $3 / 4$ s. $9-119$, sum.

Z treści: Chmielewski Zdzisław: Kierunki rozwoju współczesnej archiwistyki s. 9-24; Robótka Halina: Światowe tendencje w ksztatceniu archiwistów s. 25-42; Tandecki Janusz: Dzieje i dorobek naukowy toruńskiego uniwersyteckiego ośrodka kształcenia archiwistów s. 43-53; Chorażyczewski Waldemar, Kwiatkowska Wiesława: Kształcenie archiwistów na Uniwersytecie Mikołaja Kopernika w Toruniu w latach 1951 - 2001 s. 54-72; Kłapcińska Ewa: Kształcenie archiwistów na Uniwersytecie Wrocławskim s. 73-80; Sierpowski Stanisław: Kształcenie ustawiczne s. 96-98; Ciara Stefan: Kształcenie i pozycja zawodowa archiwistów w Galicji w okresie autonomii s. $111-119$.

31. KURCZ Alicja: Formy opieki nad dzieckiem w okresie wczesnego dzieciństwa na ziemiach polskich od połowy XVII stulecia do zakończenia I wojny światowej. W: W klimacie śląskiej humanistyki. Księga jubileuszowa dedykowana Profesorowi doktorowi hab. Franciszkowi A[ntoniemu] Markowi w pięćdziesięciolecie pracy dydaktycznej i naukowej. Red. nauk. Jolanta Kwiatek, Eleonora Sapia-Drewniak. Opole 2001 s. 225- 233.

32. LUBOJEMSKA Barbara: Zarys dziejów szkolnictwa we Frysztaku 1424 - 1984. Krosno 2001 Roksana ss. 100 .

33. MAJERSKA Alina: Pedagogika na Wyższych Kursach dla Kobiet im. A. Baranieckiego - ludzie i książki. Przegl. Hist.-Ośw. R. 44: 2001 nr 3/4 s. $95-104$.

W 1. $1893-1923$.

34. MAŃKOWSKI Stanisław: Historyczne aspekty opieki nad dzieckiem osieroconym. Wybrane problemy. Zesz. Nauk. WSHE (Włocławek). T. 9: 2001 s. 89-98. 
35. MASSALSKI Adam: Tradycje akademickie Kielc. Roczniki [Stacja Nauk. PAN w Paryżu]. T. 4: 2001 s. $41-57$.

Lata $1727-1945$.

36. MATERIAEY i studia do dziejów nauczania i wychowania religijnego. T. 2. Red. nauk. Jan Szczepaniak. Kraków 2001 Unum ss. 207, sum.

Treść: Wróbel Elena Elżbieta: „Z wychowania bowiem złego, wszystko złe idzie”. Predykanta lubelskiego [Krzysztofa Kraińskiego (1556-1618)] rady dla rodziców s. 7-23; Szczepaniak J.: Zachowane spisy alumnów Seminarium Akademickiego w Krakowie s. 25-51; Chrzaszcz Czesław: Urzędnik czy kapłan? Katecheci galicyjscy wobec konstytucyjnej reformy szkolnictwa s. 53-84; Kossakowska-Jarosz Krystyna: Wybrane problemy religijnego wychowania na Górnym Slasku w XIX stuleciu s. 85-106; Korzeniowska Wiesława: Wychowanie religijne w rodzinach różnych warstw społecznych na Górnym Śląsku - koniec wieków XIX i XX (analiza porównawcza) s. 107 - 123; Szczepaniak J.: Komisja Szkolna Episkopatu Polski 1928 - 1938 s. 125 - 176; Mieczkowski Janusz: Biskup Stanisław Rospond (1877-1958) s. 177 - 198; Urban Jacek: Marceli Ślepicki [1863-1936] - katecheta i kanonik krakowski s. $199-207$

T. 1. 2000 .

37. NIEWIADOMSKI Marek: Jadwiga Dziubińska i jej koncepcja szkół rolniczych na przykładzie Sokołówka. Przegl. Hist.-Ośw. R. 44: 2001 nr 3/4 s. 117-134.

Lata $1907-1939$.

38. OFFMAŃSKI Andrzej: W kierunku katechezy ewangelizacyjnej. Polska katecheza młodzieżowa w latach 1945 -2000. Szczecin 2001 Ottonianum ss. 274, nlb. 1.

39. OFICERSKIE szkoły piechoty w Polsce. Zarys dziejów. Praca zbior. pod red. Teodora Wójcika. Wrocław 2001 Wydaw. WSO im. Tadeusza Kościuszki ss. 240. Wyższa Szkoła Oficerska im. Tadeusza Kościuszki.

Treść: Jagiełło Zdzisław: Szkolnictwo oficerskie piechoty od Szkoły Rycerskiej do 1919 roku s. 9-29; Wójcik T.: Oficerskie szkoły piechoty II Rzeczypospolitej s. 30-70; Katolik Marek: Szkoły piechoty Wojska Polskiego w okresie II wojny światowej s. 71-106; Tenże: Oficerskie szkoły piechoty w latach 1945-1962 s. 107-150; Kajetanowicz Jerzy: Oficerska Szkoła Wojsk Zmechanizowanych im. T. Kościuszki 1962-1967 s. 15I-195; Szawerna Antoni: Działalność wychowawcza i kulturalno-oświatowa w oficerskich szkołach piechoty s. 196-234.

40. PENSJE, gimnazja, licea [poznańskie]. Kronika M. Poznania. [R. 69]: 2001 [nr] 4 s. 7-301.

Treść: Koćka-Krenz Hanna: Archeologiczne świadectwa o początkach szkolnictwa w Poznaniu s. 7-13; Źoladź-Strzelczyk Dorota: Szkoly poznańskie w okresie przedrozbiorowyn s. 14-27; Moras Justyna: Na pensji w XIX-wiecznym Poznaniu s. 28 - 45; Rzepecka Helena: Historia pensji Anny i Anastazji Danysz s. 46-54; Estkowski Ewaryst: Czego uczyć w polskich szkołach elementarnych w ogóle, a w wiejskich szczególnie? (Wypracowanie odczytane na XIII. posiedzeniu pedagogicznym w Poznaniu) s. 55-69; Męczyńska Katarzyna: Kochająca Cię opiekunka Anastazja Warnka (1838-1922) s. 70-80; Taż: „Warnkówny - zakład główny”. Wyższa szkoła żeńska Anastazji Warnka 1871-1912 5 s. 81-105; Karolczak Waldemar: Z dziejów szkółki i seminarium freblowskiego Walerii Puffke w Poznaniu w latach 1892-1915 s. 106-113; Smuszkiewicz Zdzisława: Z dawnych dziejów poznańskiej Dabrówki (1830 - 1939) s. 114 - 134; Piotrowska-Szulczewska Danuta: Z odległych wspomnień o Marii Swinarskiej s. 135-140; Małęcka Wacława: Trzy pokolenia dąbrówczanek s. 141 - 152; Skutecki Jakub: Zapomniana szkoła s. 153-160; Mrugalska-Banaszak Magdalena: O wildeckiej szkole. Kronikarski zapis z lat 1873-1923 s. 161 - 178; Jazdon Artur: Podręczniki w ofercie wydawców poznańskich (1831 - 1862) s. 179 - 190; Kowalowa Ewelina: Jan Rymarkiewicz - nauczyciel i miłośnik ksiag s. 191 - 200; Mrugalska-Banaszak M.: Budynki szkolne podmiejskich gmin właczonych do Poznania w 1900 roku s. 201 - 214; Skutecki Jakub: O budowaniu i urządzaniu szkól, czyli bryk z niemieckiego podręcznika architektury s. 215 -231; Jazdon Andrzej: „Paganinim wprawdzie nie byl...”, czyli rzecz o nauczaniu muzyki w Poznaniu do 1918 roku s. 232-250; Gulczyńska Justyna: Niepubliczne szkoły średnie ogólnokształcące w Poznaniu w okresie międzywojennym s. 251-261; Kto dzisiaj pamięta Szkolę Przygotowawcza pani [Janiny] Kusztelanowej? s. 262 - 264; Matuszak Zenon: Moje wspomnienia z lat szkolnych s. 265 - 268; Łukomski Grzegorz: Zjazdy wychowanków i profesorów Gimnazjum św. Marii Magdaleny s. 269-282; Marciniak Anna: Nauczyciele poznańscy wśród założycieli Towarzystwa Przyjaciół Nauk s. 283-301.

41. PEKALA Anna: Idee wychowania muzycznego w polskiej myśli pedagogicznej. Czesstochowa 2001 Wydaw. Wyższej Szkoły Pedagog. ss. 124, nlb. 3. XVIIl - XX w.

42. PIŁATOWICZ Józef: Żydzi na wyższych uczelniach technicznych w Polsce do 1939 roku. Kwart. Hist. Nauki i Techn. R. 46: 2001 nr 2 s. 85-112, sum. 
43. POLACY na uniwersytecie w Innsbrucku. Pod red. Edwarda Walewandra. Lublin 2001 Red. Wydaw. KUL ss. 96, tabl. 2, il Biblioteka Pedagogiczna Katedry Pedagogiki Porównawczej Wydziału Nauk Społecznych Katolickiego Uniwersytetu Lubelskiego. Ser. A: Studia. T. 4.

Treść: Walewander E.: Wprowadzenie s. 9-10; Toż w jęz. niem. s. 11-12; Walewander E.: Z dziejów Innsbrucka s. 13-16; Ćwik Władysław: Studenci i uczeni z ziem polskich na uniwersytecie w Innsbrucku do Il wojny światowej s. 17-74; Walewander E.: Polacy studenci teologii w Innsbrucku po II wojnie światowej s. 75-80; Niewiadomski Józef: Fascynujacy czas dramatycznych przełomów s. 81 - 84; Giedroyé Karol Tornasz: Duszpasterstwo polskie w Innsbrucku dzisiaj s. $85-87$.

44. POLSKA myśl pedagogiczna po 1918 roku. Praca zbiorowa. Pod red. Ewy Brodackiej-Adamowicz. Siedlce 2001 Wydaw. Akad. Podlaskiej ss. 170.

Treś: Wyszczelski Lech: Wstęp s. 5-9; Antas Alicja: Florian Witold Znaniecki (1882-1958) s. 11-25; Brodacka-Adamowicz E.: Sergiusz Hessen $(1887-1950)$ s. 27-46; Filipek Agnieszka: Stefania Sempolowska (1869-1944) s. 47-66; Grzegorczyk Barbara: Marian Ignacy Falski (1881-1974) s. 67-79; Klim-Klimaszewska Anna: Zygmunt Myslakowski (1890 - 1971) s. 81 - 93; Lipińska-Rzeszutek Matgorzata: Janusz Korczak (1878/9 - 1942) s. 95 - 106; Niewęglowska Aneta: Kazimierz Sośnicki (1883 - 1976) s. 107-119; Rzeszutek Lucjan: Helena Radlińska (1879 - 1954) s. 121 - 130; Skóra Aneta: Bogdan Suchodolski (1903 - 1992) s. 131 - 140; Trebicka-Postrzygacz Beata: Lucjan Zarzecki (1873-1925) s. 141 - 162; Wiśniewska Małgorzata: Marian Porwit (1895-1988) s. $163-170$.

45. PRZEMIANY edukacyjne $w$ Polsce $i$ na świecie a modele wychowania. I Konferencja naukowa Zakładu Teorii i Historii Wychowania. Praca zbior. pod red. Wiesławy Korzeniowskiej, Stanisława Czesława Michałowskiego, Andrzeja Murzyna. Kraków 2001 Impuls ss. 474, nlb. 1, sum. Inst. Pedagogiki. Zakł. Teorii i Historii Wychowania. Idee, Metody, Inspiracje.

Z treści: Magiera Elżbieta: Ideal wychowania państwowego w Il Rzeczpospolitej s. 15-28; Uchyła-Zroski Jadwiga: Z dziejów polskiego szkolnictwa muzycznego okresu międzywojennego (1918-1939): cele i koncepcje kształcenia muzycznego Karola Hlawiczki, Stefana Wysockiego i Tadeusza Joteyki s. 29 - 35; Król Joanna: Refleksje o wychowaniu młodzieży szkól średnich ogólnokształcacych w Polsce w latach 1948-1956 s. 37-48; Musialik Wanda: Udział zakonów w Polsce w wychowaniu i kształceniu młodzieży. Zarys problemu s. 153-163; Kurowski Błażej: Szkoła klasztoma na Górze św. Anny $1869-1875$ s. 165 -170: Sựol Ełisabeth: Dzialalność pedagogiczna i resocjalizacyjna Młodzieżowego Ośrodka Wychowawczego Zgromadzenia Sióstr Matki Bożej Miłosierdzia w Krakowie s. 171 - 185; Mirek Agata: Metody i formy wychowawcze w domach dziecka prowadzonych przez siostry Zgromadzenia Córek Maryi Niepokalanej w latach 1918 - 1939 s. 187-195; Kossakowska-Jarosz Krystyna: O języku wartości w modelu wychowania górnoślaskich dziewczat i o strażniczkach kształtowania wzorów na przelomie XIX i XX wieku s. 315-330; Szymańska Maria: Modele wychowania w rodzinach ziemiańskich ziemi plockiej (druga połowa XIX wieku) s. 331 - 338; Wojtkiewicz Lucyna: Modele wychowania w rodzinach polskich na Wileńszczyźnie. Komunikat s. $339-344$.

46. REFORMY edukacyjne w Polsce. Tradycje i współczesność. Red. Iwonna Michalska, Grzegorz Michalski. Skierniewice 2001 WSE-H ss. 255. Wyższa Szkoła Ekonomiczno-Humanist.

Z treści: Michalska I.: Wstęp s. 5-7; Hellwig Jan: Z dziejów reform oświatowych w Polsce s. 9-26; Smołalski Antoni: Teleologie reform edukacyjnych w nowożytnej Europie i w Polsce s. 27-43; Szulakiewicz Wladyslawa: Historiografia edukacyjna w Il Rzeczypospolitej wobec reform oświatowych Komisji Edukacji Narodowej s. 45-56: Jamrożek Wiesław: Reformy edukacyjne w Il Rzeczypospolitej w opinii działaczy i teoretyków ruchu ludowego s. 57-65; Michalski G.: Dyskusje Stowarzyszenia Chrześcijańsko-Narodowego Nauczycielstwa Szkół Powszechnych nad kształtem ustroju szkolnego s. 67-81; Leżańska Wiesława: Wychowanie przedszkolne w reformach Drugiej Rzeczypospolitej s. 83-95; Jakubiak Krzysztof: Instytucje samorządu szkolnego w reformach oświatowych na ziemiach polskich w XIX w. oraz II Rzeczypospolitej s. 97-107; Jałmużna Tadeusz: Pedagogika szkoły pracy w Polsce międzywojennej i jej oddzialywanie na reformy edukacyjne s. 109 - 122; Albański Leszek: Reformy systemu opieki nad dzieckiem - tradycje i wspólczesność s. 123-133; Szkoda Edward: Możliwości awansu społeczno-zawodowego nauczycieli w okresie Polski Ludowej i w warunkach obecnej reformy systemu edukacji s. 135 - 147; Kość Ilona: W poszukiwaniu europejskiego wymiaru edukacji s. 149-157; Wolter Edyta: Wychowawcze aspekty nagradzania i karania w ujęciu Józefa Wlodarskiego cenna inspiracja kreowania postaw nauczycielskich s. 241 - 247.

47. ROLA i miejsce kobiet w edukacji i kulturze polskiej. T. 2. Pod red. Wiesława Jamrożka i Doroty Żołądź-Strzelczyk. Poznań 2001 Inst. Hist. UAM ss. 335.

Z treści: Wrzosek Małgorzata: Właścicielki prywatnych wyższych szkół i pensji żeńskich w Królestwie Polskim w okresie międzypowstaniowym s. 11-24; Jędrychowska Barbara: Kobiety i zesłanki w życiu oświatowym i kulturalnym Polaków na Syberii (XIX wiek) s. 25-37; Hellwig Jan: Narcyza Żmichowska (1819-1876) jako działaczka oświatowa s. 39-45; Szmyd Kazimierz: Marcelina Darowska (1827-1911) - sylwetka i dzieło 
pedagogiczne s. 47-55; Stopińska-Pajakk Agnieszka: Wkład Izabeli Moszczeńskiej w rozwój polskjego ruchu kobiecego s. 57-68; Apanel Danuta: Aniela Szycówna w polskiej pedagogice empirycznej s. 69 - 80; Raczek Halina: Maria Weryho-Radziwillowiczowa jako organizatorka wychowania przedszkolnego na ziemiach polskich przelomu XIX i XX wieku s. 81 -87; Leżańska Wiesława: Wkład Stefanii Marciszewskiej-Posadzowej w rozwój pedagogiki przedszkolnej w Polsce s. 89-96; Horbowski Adam: Uniwersalne wartości pisarstwa pedagogicznego Heleny Radlińskiej s. 97-104; Michalska Iwonna: Wklad Heleny Radlińskiej, jej wychowanek i współpracowników w badania nad czytelnictwem dzieci i mlodzieży w dwudziestoleciu międzywojennym s. 105-110; Szulakiewicz Wladysława: Hanna Pohoska jako historyk wychowania - między nauka, ideologia a rzeczywistościa s. 111 - 122; Sapia-Drewniak Eleonora: Wkład Stefanii Mazurek w organizację oświaty polskiej na Śląsku w latach 1919-1947 s. 123-130; Michalski Grzegorz: Maria Buyno-Arctowa wychowawca młodych pokoleń Polaków s. 131-135; Góralski Jarosław: Miejsce i rola kobiety w Polskiej Macierzy Szkolnej (1905-1939) s. 137-142; Sokół Zofia: Działalność organizacji ziemianek polskich (w latach 1895 -1945) s. 157-169; Gowacka Edyta: Pierwsza Skautka Rzeczypospolitej - wkład Olgi Małkowskiej w narodziny skautingu dla dziewczat s. 191-200; Kuczyńska Ewa: Działalność Marii Łączkowskiej - organizatorki opieki logopedycznej w Poznaniu s. 201 - 207; Siwoszko Janina: Miejsce współczesnej kobiety w oświatowej kadrze kierowniczej s. 209-221; Dabrowska Joanna: Elementy tradycjonalizmu i nowoczesności w pogladach Klementyny z Tańskich Hoffmanowej na wychowanie kobiet $s$. 225 -232; Stawiak Małgorzata: Poglądy na rolę w życiu spolecznym oraz wychowanie i kształcenie kobiet na lamach czasopism i kalendarzy warszawskich w okresie międzypowstaniowym (1831 - 1863) s. 233-245; Zydlik Dorota: Rola kobiety w twórczości Cypriana Kamila Norwida s. 247-254; Harmak Agnieszka: Prototypy ról kobiecych w kanonie polskiej literatury dziewiętnastowiecznej s. 255-279; Brynkus Józef: Wizja Jadwigi - żony Jagiełly - w edukacji historycznej XIX stulecia s. 281 - 289; Kabzińska Łucja: Problem edukacji kobiet w myśli pedagogicznej Królestwa Polskiego drugiej polowy XIX wieku s. 291 - 306; Jakubiak Krzysztof: Wizerunek matkj i jej edukacja w świetle polskiego piśmiennictwa pedagogicznego i pamiętnikarstwa XIX wieku i początków XX wieku s. 307 - 318; Jamrożek W.: Kobiety w edukacji i pracy społeczno-oświatowej w świetle koncepcji galicyjskiej socjalnej demokracji s. 319-326; Koźmian Danuta: Edukacja i funkcja kobiety wiejskiej w poglądach Jadwigi Dziubińskiej i Ireny Kosmowskiej s. $327-335$.

48. SCHANKWEILER Ewald J.: Das Ringen um Schulbildung der in Galizien angesiedelten Pfälzer unter Österreich und Polen in den Jahren 1782 bis 1939. Zeitweiser der Galiziendeutschen. Jg. 38: 2000 s. $83-150$.

49. SŁAWSKA-BONARSKA Maria: Literatura muzyczna, nauczanie i upowszechnianie muzyki w dawnej Polsce od wieku X do końca XVIII. Częstochowa 2001 Wydaw. Wyższej Szkoły Pedagog. ss. 104, nlb. 2, sum.

50. STANIK Stanisław: Nauczanie szkolne w Studziannie-Poświętnem. Muzeum Szkolne. Nr 46. Wkładka do czasop. Wiadom. Hist. R. 44: 2001 nr 3 s. $43-48$.

XVIII - XX w.

51. STARNAWSKI Jerzy: O granicach wolności. Symbolae Philologorum Posnaniensium Graecae et Latinae. Vol. 13: 2000 s. $103-108$.

Problem wolności wykładów profesorskich w XX w.

52. SUCHMIEL Jadwiga: Poglądy na wychowanie Kazimierza Twardowskiego (na podstawie prac niefilozoficznych) W: Przyzywanie głębi do kręgu słów, myśli, idei i działań. Księga jubileuszowa ofiarowana Profesorowi Józefowi Żurawowi. Pod red. Stanisława Podobińskiego i Bogdana Snocha. Częstochowa 1999-2000-2001 s. 291-299.

53. SUCHOŃSKI Adam: Obraz panowania Habsburgów w podręcznikach do nauczania historii. W: Śląsk za panowania Habsburgów. Slezko v dobẽ panování Habsburku. Schlesien unter der Herrschaft der Habsburger. Red. nauk. Wiesław Lesiuk, Michał Lis. Opole 2001 s. $101-108$.

54. URBAN Wacław: Tragedia kulturalna Polski. Umiejętność pisania i czytania od połowy XVI do połowy XIX wieku. Roczn. Bibl. Nauk. PAU $i$ PAN w Krakowie. R. 46: 2001 s. $165-174$, sum.

55. W SŁUŻBIE nauce i szkole. Pod red. A. Wojciecha Maszke. Rzeszów 2001 Wydaw. Wyższej Szkoły Pedagog. ss. 188, tabl. 1.

Księga pamiatkowa Jana Kidy. 
56. WAKSMUND Ryszard: Od literatury dla dzieci do literatury dziecięcej (Tematy, gatunki, konteksty). Wrocław 2000 Wydaw. Uniw. Wrocławskiego ss. 443.

XVIII $-\mathrm{XX}$ w.

Rec.: Leszczyński Grzegorz: Próba syntezy. Nowe Ksiażki. [R. 51]: 2001 nr 8 s. 15.

57. ZAKRZEWSKI Andrzej J.: Tradycje kształcenia humanistycznego w Częstochowie. Biuletyn [Inst. Filoz.-Hist. WSP w Częstochowie]. [Nr] 28: 2001 s. 8-16.

Od XVI w.

58. ZALEWSKA-PAWLAK Mirosława: Rola sztuki w wychowaniu. Polska tradycja pedagogiczna. Łódź 2001 Wydaw. UŁ ss. 212, nlb. 1, riass. Rozprawy Habilitacyjne Uniwersytetu Łódzkiego. $\mathrm{XVI}-\mathrm{XX}$ w.

59. ZWOLSKI Czesław Tadeusz: Handel, szkolnictwo i stowarzyszenia kupieckie w Radomiu. Szkic historyczno-gospodarczy. Radom 2001 WSH; współpr. wydaw. Inst. Technologii Eksploatacji ss. 140, il., mapa. Wyższa Szkoła Handlowa w Radomiu.

60. ŻOŁADŹ-STRZELCZYK Dorota, Jamrożek Wiesław: Studia z dziejów edukacji kobiet na ziemiach polskich. Poznań 2001 Bajt ss. 152. Wydz. Studiów Edukacyjnych Uniw. im. A. Mickiewicza w Poznaniu.

\section{Okres do 1795 roku}

61. BALCZEWSKI Marian: Gry i zabawy Turków osmańskich na podstawie polskich i obcych źródeł od schyłku Średniowiecza do końca Oświecenia. Warszawa 2000 Dialog ss. 237, nlb. 3. Świat Orientu.

Rec.: Dziekan Marek M., Przegl. Orientalist. [R. 49]: 2001 nr 1/2 s. 124-125.

62. BAECZEWSKI Marian: Znajomość edukacji Turków osmańskich w Polsce od schyłku Średniowiecza do końca Oświecenia. Warszawa 2001 Dialog ss. 281, nlb. 1. Świat Orientu.

63. BURDA Bogumiła: Życie codzienne ucznia w nowożytnej szkole średniej na Dolnym Śląsku w XVI i XVII wieku. W: Ziemie Zachodnie. Polska-Niemcy. Integracja europejska. Księga pamiątkowa z okazji siedemdziesiątej rocznicy urodzin prof. dra hab. Hieronima Szczegóły. Red. nauk. Czesław Osękowski. Zielona Góra 2001 s. 371 -380.

64. CHACHAJ Marian: Promocje doktorskie biskupów, prałatów i kanoników katedralnych krakowskich na Uniwersytecje Bolońskim od schyłku XV do końca XVII wieku. W: Kościół katolicki w Małopolsce w średniowieczu i we wczesnym okresie nowożytnym. Pod red. Waldemara Kowalskiego, Jadwigi Muszyńskiej. Kielce-Gdańsk 2001 s. 439-453.

65. DEC Ignacy: Życie sakramentalne, kultowe i nauczanie religijne $w$ archiprezbiteriacie żorskim w XVII w. w świetle wizytacji biskupich. Ślaski Kwart. Hist. Sobótka. R. 56: 2001 nr 3 s. $503-514$, Zsfg.

66. GRZEBIEŃ Ludwik: Czy Stanisław Konarski SP był natchnieniem dla jezuitów w reformie szkolnictwa?. Analecta. R. 10: 2001 nr 2 s. 53-66, sum.

67. GULBINOWICZ Henryk: Odrodzenie Akademii Wileńskiej w XVIII wieku. W: W klimacie śląskiej humanistyki. Księga jubileuszowa dedykowana Profesorowi doktorowi hab. Franciszkowi A[ntoniemu] Markowi w pięćdziesięciolecie pracy dydaktycznej i naukowej. Red. nauk. Jolanta Kwiatek, Eleonora Sapia-Drewniak. Opole 2001 s. $107-115$.

68. KACZMAREK Krzysztof: Dlaczego cystersi z „Prus” nie chcieli studiować w Krakowie? W: Cystersi na Kujawach i na Pomorzu. Nasza Przeszłość. [T.] 96: 2001 s. $195-207$, sum., Zsfg. 
69. KARNICKA Magdalena: Medale nagrodowe liceum przy kościele Pokoju w Świdnicy w zbiorach Muzeum Narodowego we Wrocławiu. Roczn. Świdnicki. T. 28: 2001 s. 34-36.

XVIII w.

70. KONIOR Alojzy: Stanisław Leszczyński jako patron szkół. W: Stanisław Leszczyński - król, polityk, pisarz, mecenas. Materiały z europejskiej konferencji naukowej zorganizowanej w 300-lecie urodzin króla Stanisława Leszczyńskiego. Pod red. Alojzego Koniora. Leszno 2001 s. 223-229.

71. KRUKOWSKI Jan: Szkolnictwo parafialne Krakowa w XVII wieku. Kraków 2001 Wydaw. Nauk. AP ss. 422, nlb. 2, sum. Akad. Pedagog. im. Komisji Edukacji Nar. w Krakowie. Prace Monograficzne. Nr 319.

72. KRZYŻANIAKOWA Jadwiga: Ostatni Polacy na Uniwersytecie praskim w XV wieku. W: Scriptura custos memoriae. Prace historyczne. Pod red. Danuty Zydorek. Poznań 2001 s. 437-459.

73. KWAŚNIEWICZ Krzysztof: „Lapis mutus sum, loqui tamen coactus”. Sarmackie nagrobki profesorów Uniwersytetu Jagiellońskiego. W: Sarmackie theatrum. Materiały z konferencji naukowej, Katowice 9-11 grudnia 1998 roku. [T.] 1: Wartości i słowa. Pod red. Renardy Ocieczek; przy współudz. Bożeny Mazurkowej. Katowice 2001 s. $138-150$.

74. LEC Zdzisław: Sprowadzenie jezuitów do Wrocławia i ich działalność związana z utworzeniem uniwersytetu w 1702 r. W: Milenijny Kościół wrocławski wczoraj i jutro. Praca zbior. pod red. Ignacego Deca. Wrocław 2001 s. $89-108$.

75. MARKOWSKI Mieczysław: Die heilige Hedwig - Gründerin der Universität in Krakau. Acta Mediaevalia. T. 13: 2000 s. $75-91$, streszcz.

76. MICHALIK Bożenna: Dzieje wychowania i szkolnictwa w Warszawie stanisławowskiej. Warszawa 2001 Żak ss. 166, nlb. 1.

77. MOKRZECKI Lech: Wokół staropolskiej nauki i oświaty. Gdańsk - Prusy Królewskie

- Rzeczypospolita. Gdańsk 2001 Wydaw. Gdańskie ss. 486. Gdańskie Tow. Nauk.

XVI-XVIII w.

Rec.: Bieńkowski Tadeusz, Odrodzenie i Reformacja w Polsce. T. 45: 2001 s. $291-292$.

78. NAWORSKI Zbigniew: Henryk Stroband (1548 - 1609) i jego koncepcja opieki nad sierotami. W: Honeste vivere... Księga pamiątkowa ku czci Profesora Władysława Bojarskiego. Red. nauk. Ewa Gajda, Andrzej Sokala. Toruń 2001 s. 535-547.

79. PIECHNIK Ludwik: Seminaria diecezjalne w Polsce prowadzone przez Jezuitów od XVI do XVIII wieku. Kraków 2001 Wydaw. WAM; Wyższa Szkoła Filoz.-Pedagog. „Ignatianum” ss. 282, nib. 21, i1., mapa, sum. Studia i Materiały do Dziejów Jezuitów Polskich. T. 6.

80. PUCHOWSKI Kazimierz: „In bello Mars, in pace Apollo”. Z dziejów edukacji w kolegiach jezuickich Rzeczypospolitej Obojga Narodów. W: Jezuicka ars historica. Prace ofiarowane Księdzu Profesorowi Ludwikowi Grzebieniowi SJ. Red. Marek Inglot, Stanisław Obirek. Kraków 2001 s. $479-498$.

81. SALMONOWICZ Stanisław: Cycero w murach toruńskiego Gymnasium Academicum (XVII - XVIII w.). W: Honeste vivere... Księga pamiątkowa ku czci Profesora Wladysława Bojarskiego. Red. nauk. Ewa Gajda, Andrzej Sokala. Toruń 2001 s. 589-601.

82. SCZANIECKI Stefan: Podręcznik pedagogiki Stefana Sczanieckiego SJ z 1715 roku. Pedagogic Manual of Stefan Sczaniecki SJ from the year 1715. Professio circa puerorum in virtute, sapientia et politie institutionem. Oprac. Jerzy Kochanowicz; tekst przetł. Jan Ożóg; tł. Reguł wspólnych dla nauczycieli klas niższych Agnieszki Stachowicz. Kraków 200l WAM; Wyższa Szkoła Filoz.-Pedagog. „Ignatianum” ss. 156, nlb. 1, sum. Studia i Materiały do Dziejów Jezuitów Polskich. T. 5.

Tekst równol. pol., lac. 
83. SOŁTAN Aleksander: Contubernium Philosophorum - krakowska fundacja biskupa plockiego Andrzeja Noskowskiego. Przegl. Hist. T. 92: 2001 z. 1 s. 15-42, sum.

84. STASIEWICZ-JASIUKOWA Irena: O współpracy jezuicko-pijarskiej w Towarzystwie do Ksiag Elementarnych. „Concordia parvae res crescunt, discordia vel maximae dilabuntur”. W: Jezuicka ars historica. Prace ofiarowane Księdzu Profesorowi Ludwikowi Grzebieniowi SJ. Red. Marek Inglot, Stanisław Obirek. Kraków 2001 s. $515-538$.

85. SWASTEK Józef: Formacja naukowa kandydatów do kapłaństwa we Wrocławiu w czasach nowożytnych i spór o pierwsze seminarium na ziemiach polskich. Slasski Kwart. Hist. Sobótka. R. 56: $2001 \mathrm{nr} 3$ s. $547-554$, Zsfg.

86. TARASZKIEWICZ Jacek: Pijarski teatr szkolny inspiracją edukacji patriotycznej i obywatelskiej w Rzeczypospolitej Obojga Narodów w latach 1648-1740. Lubelski Roczn. Pedagog. T. 21: 2001 s. $195-206$.

87. TAZBIR Janusz: Stosunek do dziecka w okresie staropolskim. W: Dzieci bija. Warszawa 2001 s. $19-33$.

88. WLAŹLIK Barbara: Wychowanie dziewcząt w dobie renesansu. Wiadom. Hist. R. 44: 2001 nr 2 s. $110-104$.

89. WRÓBEL-LIPOWA Krystyna: Miejsce i rola edukacji historycznej w szkolnictwie arianizmu polskiego. Res Historica. Z. 10: 2000 s. $141-145$.

90. ZIÓŁEK Ewa: Działalność Grzegorza Piramowicza w Komisji Edukacji Narodowej. W: Grzegorz Piramowicz [1735-1801] i jego epoka. Pod red. Krzysztofa Andrzeja Boreczka, Adama Andrzeja Witusika. Kurów 2001 s. $81-91$.

\section{Okres $1795-1918$}

91. BAŁABAN Majer: W sprawie szkolnictwa dla Żydów w Królestwie Polskim. Kwart. Historii Żydów. [R. 1]: $2001 \mathrm{nr} 1$ s. $69-72$.

I wojna šwiatowa.

92. BANACH Andrzej K[azimierz]: Das polnische Schulwesen für Flüchtlinge aus Galizien und der Bukowina in der Österreichisch-Ungarischen Monarchie während des Ersten Weltkrieges. W: Aus der Geschichte Österreichs in Mitteleuropa. H. 2: Kultur und Bildung. Red. Zofia Kowalska. Wien 2000 [druk.: 2001] s. $79-107$.

93. BIENIEK Maria: Joachim Lelewel jako twórca podręcznikowej kartografii historycznej (do 1830 r.). W: W kraju i na wychodźstwie. Księga pamiątkowa ofiarowana Profesorowi Sławomirowi Kalembce w sześćdziesięciolecie urodzin. Toruń-Olsztyn 2001 s. 899-906.

94. BIENIEK Maria: Materiał kartograficzny w polskich podręcznikach historii doby międzypowstaniowej (1831-1863). Echa Przeszłości. [T.] 2: 2001 s. 199-208, sum.

95. BORKOWSKA Małgorzata: Seminarium galicyjskiej prowincji szarytek (1782 - 1914) w świetle badań ogólnych nad rekrutacja do polskich zakonów żeńskich. Nasza Przeszłość. [T.] 95: 2001 s. $167-195$, sum.

96. CIMAŁA Bogdan: Wychowanie pozaszkolne młodzieży polskiej na Gómym Śląsku do 1918 roku jako czynnik zachowania tożsamości narodowej. W: W klimacie śląskiej humanistyki. Księga jubileuszowa dedykowana Profesorowi doktorowi hab. Franciszkowi A[ntoniemu] Markowi w pięćdziesięciolecie pracy dydaktycznej i naukowej. Red. nauk. Jolanta Kwiatek, Eleonora Sapia-Drewniak. Opole 2001 s. $43-56$. 
97. CZACHOWSKA Katarzyna: Drogi edukacji generałowej Jadwigi z Działyńskich Zamoyskiej. Pamiętn. Bibl. Kórnickiej. Z. 25: 2001's. $173-189$.

Lata 40-te XIX w.

98. DUDAŁA Halina: Młodzież żydowska w gimnazjach Górnego Ślaska w drugiej połowie XIX i na początku XX w. (ze szczególnym uwzględniem Królewskiej Huty). Zesz. Chorzowskie. T. 4: 1999 [druk.:] 2000 s. $13-33$, Zsfg.

99. FEHRS Jörg H.: ,,..., dass sie sich mit Stolz Juden nennen”. Die Erziehung jüdischer Kinder in Ost- und Westpreussen im 19. Jahrhundert. W: Zur Geschichte und Kultur Juden in Ost- und Westpreussen. Hrsg. von Michael Brocke, Margret Heitmann und Harald Lordik. Hildesheim-Zürich-New York 2000 s. 239-280.

100. GARSTKA Aneta: Twórczość Aleksandra Świętochowskiego w galicyjskiej edukacji polonistycznej (1865 - 1914). (Komunikat). W: Świętochowski i rówieśnicy - Kotarbiński, Urbanowska, Zalewski. Sesja w 150. rocznicę ich urodzin, Zakopane, 4-6 maja 1999. Red. nauk. Bogdan Mazan i Zbigniew Przybyła. Kraków 2001 s. 189 - 194.

101. GRZEŚ Bolesław: Polityka germanizacyjna rządu pruskiego - społeczeństwo Wielkopolski w walce z germanizacją (w 100. rocznicę strajku Dzieci Wrzesińskich). Przegl. Hist.-Ośw. R. 44: 2001 nr $3 / 4$ s. $49-71$.

102. GWIAZDOWSKA Ewa, Dröge Kurt: Nauka rysunku w gimnazjach pomorskich w XIX wieku. Mater. Zachodniopomorskie. T. 46: 2000 [druk.:] 2001 s. $321-372$, Zsfg.

103. HABRAT Anna: Leon Petrażycki o roli i zadaniach uniwersytetu. Rzeszowskie Zesz. Nauk. Prawo-Ekonomia. T. 30: 2001 s. 7 - 19, sum.

Z pracy „Universitiet i nauka” (Petersburg 1907).

104. HISTORIA Elblaga. T. 3 cz. 2: (1851-1920). Pod red. Andrzeja Grotha. Gdańsk 2001 Marpress ss. 348 , tabl. 29, il., mapy.

Z treści: Wajda Kazimierz: Oświata i kultura s. 116-160.

105. HISTORIA Pomorza. T. 3: (1815-1850). Cz. 3: Kultura artystyczna i umysłowa. Pod red. Gerarda Labudy. Poznań 2001 Wydaw. PTPN ss. 268, nlb. 4, il. Poznańskje Tow. Przyj. Nauk.

Z treści: Serczyk Jerzy: Nauka i szkolnictwo wyższe s. 105-125; Niedzielska Magdalena: Szkolnictwo powszechne i średnie oraz oświata s. 127-171.

106. JEMIELITY Witold: Duchowieństwo katolickie w szkolnictwie elementamym Królestwa Polskiego. Studia Podlaskie. T. 11: 2001 s. $51-72$, sum.

107. KACZOROWSKI Włodzimierz: Lekarskie fundacje stypendialne dla studentów Uniwersytetu Wrocławskiego w drugiej połowie XIX wieku. Gómoślaska Fundacja Stypendialna Jerzego Goreckiego. W: W klimacie śląskiej humanistyki. Księga jubileuszowa dedykowana Profesorowi doktorowi hab. Franciszkowi A[ntoniemu] Markowi w pięćdzjesięciolecie pracy dydaktycznej i naukowej. Red. nauk. Jolanta Kwiatek, Eleonora Sapia-Drewniak. Opole 2001 s. 187-198.

108. KALEMBKA Urszula, Kalembka Sławomir: Memoriał z poczatku XIX wieku o zadaniach kształcacych Akademii i studiach prawniczych (wyciag ze zbioru rękopisów Uniwersytetu Wileńskiego). W: Honeste vivere... Księga pamiątkowa ku czci Profesora Władysława Bojarskiego. Red. nauk. Ewa Gajda, Andrzej Sokala. Toruń 2001 s. $505-514$.

109. KARCZ Eugenia: Rola Towarzystwa Pedagogicznego Polskiego (1848-1853) w integrowaniu nauczycieli zaboru pruskiego. W: W klimacie śląskiej humanistyki. Księga jubileuszowa dedykowana Profesorowi doktorowi hab. Franciszkowi A[ntoniemu] Markowi w pięćdziesięciolecie pracy dydaktycznej i naukowej. Red. nauk. Jolanta Kwiatek, Eleonora Sapia-Drewniak. Opole 2001 s. $219-224$. 
110. KLEJN Zbigniew: Polacy na uniwersytecie sofijskim. Mazowieckie Studia Humanist. R. 6: $2000 \mathrm{nr} 1 / 2$ [druk.:] 2001 s. $187-197$.

Lata $1889-1918$.

111. KOWALSKI Tadeusz [Antoni]: Pułtuscy nauczyciele i młodzież szkolna w walce o niepodległość kraju w latach 1905 -1918. W: Warszawa i Mazowsze w walce o niepodległość kraju w latach 1794-1920. Pod red. nauk. Adama Koseskiego i Andrzeja Stawarza. Warszawa 2001 s. 359-362.

112. KRAMARZ Henryka: Krakowska „Gazeta Szkolna” (1902 - 1913) i geneza jej radykalizmu w krytyce galicyjskiej oświaty ludowej. W: Kraków - Lwów. Książki, czasopisma, biblioteki XIX i XX wieku. T. 5. Pod red. Jerzego Jarowieckiego. Kraków 2001 s. 545-551.

113. KULA Ewa: Zainteresowania naukowe nauczycieli zatrudnionych $w$ rzadowych męskich szkołach śređnich w Kielcach w latach $1833-1862$. Roczn. Świętokrzyski. Ser. A: Nauki Humanist. T. 26: 1999 [druk.:] 2001 s. $19-32$.

114. KULKA Bronisława: Pierwiastki czeskie w działalności samokształceniowej młodzieży polskiej na Śląsku Cieszyńskim (1842-1918). W: Przyzywanie głębi do kręgu słów, myśli, idei i działań. Księga jubileuszowa ofiarowana Profesorowi Józefowi Żurawowi. Pod red. Stanisława Podobińskiego i Bogdana Snocha. Częstochowa 1999-2000-2001 s. 111-122.

115. KUZICKA Elżbieta: Szkolnictwo ludowe w Sanoku w okresie autonomii galicyjskiej 1867-1914. Prace Hist.-Archiw. T. 10: 2001 s. 49-68, sum.

116. LINDMAJER Józef: Sławieńskie szkolnictwo prywatne w XIX wieku. Dorzecze. Nr 10: 2000 s. $4-19$, tabl.

117. ŁUKASIEWICZ Dariusz: Liczba szkół elementarnych w Wielkopolsce w 1799 r. W: Dyplomacja, polityka, prawo. Księga pamiatkowa ofiarowana Profesorowi Henrykowi Kocójowi w siedemdziesiata rocznicę urodzin. Pod red. Idziego Panica. Katowice 2001 s. 325-330.

118. LUKASIEWICZ D.: Statystyka szkolna Prus Południowych z 1799 roku. Zapiski Hist. T. 66: 2001 z. $2 / 3$ s. $57-80$, Zsfg.

119. MARTUSZEWSKI Edward: „Die polnische Sprachfrage in Preussen” Gustawa Gizewiusza jako źródło do badań nad dziejami germanizacji szkolnictwa na Mazurach. Olsztyn 2001 OBN ss. VI, 270, nlb. 1, tabl. 1, Zsfg. Rozprawy i Materiały Ośrodka Badań Naukowych im. Wojciecha Kętrzyńskiego w Olsztynie. Nr 200.

120. MASSALSKI Adam: Szkoły średnie rzadowe męskie na ziemi kielecko-radomskiej w latach 1833-1862. Kielce 2001 Wydaw. AŚ ss. 337, nlb. 1, il. Inst. Historii Akad. Świętokrzyskiej w Kielcach. Prace Instytutu Historii Akademii Świętokrzyskiej w Kielcach. Nr. 28. Historia.

121. MILEWSKI Stanisław: Pokłosie Szkoły Głównej (przygotowanie zawodowe adwokatów w drugiej połowie XIX w.). Cz. 1-2. Palestra. R. 45: 2001 nr 3/4 s. $97-101$; nr 5/6 s. $74-78$.

122. MILEWSKI S.: „Uczniowie okazali się należycie usposobieni”. (Przygotowanie zawodowe adwokatów w Królestwie Polskim w okresie między powstaniami). Palestra. R. 45: $2001 \mathrm{nr}$ 1/2 s. $70-79$.

123. MILLER Jerzy: Strajki szkolne w Wielkopolsce w latach 1901-1907. Przegl. Hist.-Ośw. R. 44: 2001 nг $3 / 4$ s. $73-81$.

124. OKRASA Marzena: Internat i stancje dla młodzieży zamiejscowej funkcjonujące w Lublinie w latach 1864-1905. Przegl. Hist.-Ośw. R. 44: 2001 nr 1/2 s. 83-95.

125. OKRASA M.: Pensjonat działajacy w Lublinie w latach 1859 - 1863. Przegl. Hist.-Ośw. R. 44: 2001 nr $3 / 4$ s. $83-94$. 
126. PETRY-WECŁAWOWICZ Małgorzata: Edukacja plastyczna dawniej. Programy, metody, inicjatywy pozaszkolne do 1914 roku. Kraków 2001 Wydaw. Nauk. AP ss. 249, nlb. 2, il. Akad. Pedagog. im. Komisji Edukacji Narod. w Krakowie. Prace Monograficzne. Nr 276.

$\mathrm{XIX}-\mathrm{XX}$ w.

127. PIPOWSKI Roman: Szkolnictwo elementarne w powiecie toruńskim w latach $1772-1920$. Toruń 2001 Wydaw. Adam Marszałek ss. 173, Zsfg., sum.

128. POZNAŃSKI Karol: Oświata i szkolnictwo w Królestwie Polskim 1831 - 1869. Lata zmagań i nadziei. [T.] 1: Przebudowa systemu szkolnictwa i wychowania w Królestwie Polskim w latach 1831 - 1839. Warszawa 2001 Akad. Pedagogiki Specjalnej im. Marii Grzegorzewskiej ss. 190.

Toż. [T.] 2: Szkoły rzemieślniczo-niedzielne. Warszawa 2001 ss. 155.

129. REIZES-DZIEDUSZYCKI Jerzy: Poczatki działalności Czytelni Akademickiej w Lwowie (1867-1877). Roczniki Bibliot. R. 45: 2001 s. $199-214$, sum.

130. RUSECKI Innocenty [Marek]: Szkolnictwo elementarne Bernardynów na przełomie XVIII-XIX wieku. Studia Franciszkańskie. [T.] 11: 2001 s. 307-325, riass.

131. SKORUPKA Anna: Losy inspektora Jakuba Andriejewskiego i nauczyciela Merkurija Murawiewa z Seminarium Nauczycielskiego w Jędrzejowie. Roczn. Świętokrzyski. Ser. A: Nauki Humanist. T. 26: 1999 [druk.:] 2001 s. 93 - 99.

W 1. 80-tych i 90-tych XIX w.

132. SŁOWIŃSKI Lech: Twórczość Adama Mickiewicza w obiegu szkół średnich Wielkiego Księstwa Poznańskiego. W: Od romantyzmu do współczesności. W kręgu historii i dydaktyki literatury. Tom poświęcony profesorowi Mieczysławowi Inglotowi z okazji 70. rocznicy urodzin. Pod red. Władysława Dynaka. Wrocław 2001 s. 13-27.

133. SNOCH Bogdan: Polska szkoła średnia w Galicji w pierwszych latach wojny 1914/15 - 1915/16. W: Przyzywanie głębi do kręgu słów, myśli, idei i działań. Księga jubileuszowa ofiarowana Profesorowi Józefowi Żurawowi. Pod red. Stanisława Podobińskiego i Bogdana Snocha. Częstochowa 1999-2000-2001 s. 271-275.

134. SOCHA Irena: „Przykładne, użyteczne i zabawne”. O polskich książkach dla młodego odbiorcy na Śląsku w drugiej połowie XIX i na początku XX wieku. Katowice 2001 Wydaw. UŚ ss. 175, nlb. 1, tabl. 16, il., sum., Zsfg. Prace Naukowe Uniwersytetu Śląskiego w Katowicach. Nr 1927.

135. STARNAWSKI Jerzy: Łacińskie biogramy wybitnych wychowanków Liceum Warszawskiego z pierwszych dziesiątków lat XIX wieku. Meander. R. 55: $2000 \mathrm{nr} 6$ s. 573-574, argum.

Lata $1817-1823$.

136. STEPNIEWSKA-HOLZER Barbara: Żydowskie szkoły religijne i państwowe w guberniach białoruskich Cesarstwa Rosyjskiego w I połowie XIX wieku. Kwart. Historii Żydów. [R. 1]: $2001 \mathrm{nr}$ ] s. $3-15$, sum.

137. STRAJK szkolny we Wrześni w 1901 r. Sesja popularnonaukowa zorganizowana w dniu 11.05.2001 r. w 100. rocznicę strajku Dzieci Wrzesińskich. Red. Bolesław Święciochowski. Września 2001 WTK ss. 100, il. Wrzesińskie Tow. Kult., Muzeum Regionalne we Wrześni. Biblioteczka WTK. [Nr] 5 .

Treść: Święciochowski B.: Polacy wobec germanizacji w zaborze pruskim w II połowie XIX wieku s. 7 - 19; Kostrzewski Leopold: Przebieg strajku szkolnego we Wrześni w 1901 roku s. 21 - 45; Szuba Siawomir: Działalność ks. Jana Laskowskiego w czasie strajku dzieci wrzesińskich w 1901 r. s. 47-56; Korfini-Stachnik Małgorzata: Echa strajku Dzieci Wrzesińskich s. 57-67; Lenartowicz Janusz: Pamięć o wydarzeniach wrzesińskich z roku 1901 s. 69-94; Kulczycki John J.: Znaczenie strajku Dzieci Wrzesińskich s. 95-100.

138. SUDOLSKI Zbigniew: Zagubione wartości moralno-wychowawcze, czyli o młodzieży filomacko - filareckiej i jej losach. W: Od romantyzmu do współczesności. W kręgu historii i dydaktyki 
literatury. Tom poświęcony profesorowi Mieczysławowi Inglotowi z okazji 70. rocznicy urodzin. Pod red. Władysława Dynaka. Wrocław 2001 s. $184-196$.

139. SZABAT Barbara: Walka o szkołę polską w okresie rewolucji 1905-1907 w guberni kieleckiej. Wyd. 2 popr. i uzup. Kielce 2001 Wydaw. AŚ ss. 362, nlb. 3, il. Inst. Historii Akad. Świętokrzyskiej w Kielcach. Prace Instytutu Historii Akademii Świętokrzyskiej w Kielcach. Nr 24. Historia.

Wyd. 1. 1991.

140. SZCZYGIEŁ Mirosława: Miejsce i rola szkół rzemieślniczo-niedzielnych w strukturze oświaty polskiej XIX wieku (na przykładzie szkoły rzemieślniczo-niedzielnej w Częstochowie). W: Przyzywanie głębi do kręgu słów, myśli, idei i działań. Księga jubileuszowa ofiarowana Profesorowi Józefowi Żurawowi. Pod red. Stanisława Podobińskiego i Bogdana Snocha. Częstochowa 1999-2000-2001 s. $781-787$.

141. SZEWS Jerzy, Kustosz Gaudenty A.: Nieznany regulamin szkoły klasztornej Ojców Reformatów w Wejherowie z 1807 r. i inne okoliczności jej funkcjonowania. Univ. Gedanensis. R. 13: 2001 nr 24 s. $95-101$.

142. URBAŃSKI Stanisław: Działalność wychowawcza bł. Marceliny Darowskiej [1827-1911] na tle epoki. Saeculum Christianum. R. 8: 2001 nr 2 s. 79-96, sum.

143. WESELIK-GINTER Agnieszka: Wychowanie seksualne dzieci i młodzieży na ziemiach polskich w drugiej połowie XIX i w pierwszych dziesięcioleciach XX wieku. Katedra. 2001 [nr] 4 s. $52-79$.

144. WLAŹLAK Władysław: Szkoły elementarne w okręgu pajęczańskim (1808 - 1832). Częstochowa 2001 Wydaw. Akad. Polonijnej „Educator” ss. 150.

145. WOLCZUK Janina: Literatura rosyjska w szkołach Królestwa Polskiego w okresie międzypowstaniowym. Acta Univ. Wratislaviensis No 2288: Slavica Wratislaviensia. [T.] 112: 2001 s. 7 -21, rez.

146. WRÓBLEWSKA Teresa: Towarzystwo Moralnych Interesów Ludności Polskiej pod Panowaniem Pruskim i Towarzystwo Oświaty Ludowej w latach 1871-1914. Ars Educandi. [Z.] 2: 2000 s. $57-73$, sum.

147. WRZOSEK Małgorzata: Prywatne, wyższe szkoły i pensje męskie w Kielcach w okresie międzypowstaniowym. Roczn. Świętokrzyski. Ser. A: Nauki Humanist. T. 26: 1999 [druk.:] 2001 s. 33 - 54 .

148. ŹRÓDŁA do dziejów wychowania w rodzinie polskiej w XIX i początkach XX wieku. Wybór i oprac. Andrzej Denisiuk, Krzysztof Jakubiak. Bydgoszcz 2001 Wydaw. Akad. Bydgoskiej im. Kazimierza Wielkiego ss. 290.

\section{Okres $1918-1939$}

149. BANACH Czesław: Przemiany pedagogiczno-oświatowe i społeczne w uchwałach IV Kongresu Pedagogicznego. Przegl. Hist.-Ośw. R. 44: 2001 nr 1/2 s. $39-49$.

W $1937 \mathrm{r}$.

150. FISCH Bernhard: Flaga ze swastyką na budynku szczycieńskiego gimnazjum w 1931 roku. Roczn. Mazurski. T. 5: 2001 s. $43-48$.

151. GAJEWSKI Stanisław: Pojęcie „,nacjonalizm” wśród młodzieży narodowej (1918 - 1939). Echa Przeszlości. [T.] 1: 2000 s. 135 - 143. 
152. GLIMOS-NADGÓRSKA Anna: Prawa i obowiazki nauczycieli szkół powszechnych województwa śląskiego. (Pragmatyka nauczycielska 1922 - 1939). Prace Nauk. Uniw. Ślaskiego w Katowicach. Nr 1991: Wieki Stare i Nowe. T. 2: 2001 s. 156-172, sum. s. 346-348, Zsfg s. 349-352.

153. GLIMOS-NADGÓRSKA A.: Szkolnictwo powszechne $w$ powiecie świętochłowickim (1922 - 1939). Roczn. Świętochtowicki. T. 3: 2001 s. 48-116, Zsfg.

154. GULCZYŃSKA Justyna: Rozwój szkolnictwa średniego ogólnokształcacego w Poznaniu w okresie międzywojennym 1918 - 1939. Poznań 2001 Eruditus ss. 150, nlb. 1. Wydz. Studiów Edukacyjnych Uniw. im. A. Mickiewicza w Poznaniu.

155. JEZIORSKI Herbert: Stan szkolnictwa tarnogórskiego w latach międzywojennych. Wkład duchowieństwa katolickiego i sióstr zakonnych. W: W klimacie śląskiej humanistyki. Księga jubileuszowa dedykowana Profesorowi doktorowi hab. Franciszkowi A[ntoniemu] Markowi w pięćdziesięciolecie pracy dydaktycznej i naukowej. Red. nauk. Jolanta Kwiatek, Eleonora Sapia-Drewniak. Opole 2001 s. $152-162$.

156. KESIK Jan: Praca oświatowo-wychowawcza wśród mniejszości narodowych w Wojsku Polskim 1918 - 1939. W: Mniejszości narodowe i wyznaniowe w siłach zbrojnych Drugiej Rzeczypospolitej 1918 -1939. Zbiór studiów. Pod red. Zbigniewa Karpusa i Waldemara Rezmera. Toruń 2001 s. $209-232$.

157. KNOPEK Dorota: Świadomość patriotyczno-narodowa młodzieży chojnickiej w Drugiej Rzeczypospolitej. W: Polityka regionalna a historyczna i obronna świadomość Polaków. W 80. rocznicę przyłązenia Chojnic do Drugiej Rzeczypospolitej. Red. Jacek Knopek i Adam Marcinkowski. Bydgoszcz 2001 s. $147-155$.

158. KORDEK Agnieszka: Dokształcanie podyplomowe lekarzy w Polsce w okresie międzywojennym (1918-1939). Archiwum Hist. i Filoz. Med. T. 64: 2001 z. 4 s. $265-271$, sum.

159. KOZERA Andrzej: Oświata i doradztwo rolnicze $w$ województwie kieleckim $w$ latach 1918-1939. Roczn. Świętokrzyski. Ser. A: Nauki Humanist. T. 26: 1999 [druk.:] 2001 s. 127-140.

160. KURLENDA Piotr: Stowarzyszenie Świetlic Charytatywnych na Pomorzu w czasach II Rzeczypospolitej. Paedagogia Christiana. [Nr] 7: 2001 [z.] 1 s. $147-156$.

Lata $1935-1938$.

161. ŁAZIKIEWICZ Anna: Działalność Towarzystwa Czytelni Ludowych w Chorzowie w latach 1922-1939. Zesz. Chorzowskie. T. 4: 1999 [druk.:] 2000 s. 76-92, Zsfg.

162. MORAWSKI Tomasz: Losy wychowanków Szkoły Podchorążych Sanitarnych pierwszych dziewięciu promocji (1922-30). Na podstawie archiwum dr Romana Jakubskiego. Medycyna Nowozytna. T. 8: 2001 z. 2 s. 95 -130, sum., Zsfg.

163. NARTONOWICZ-KOT Maria: Ignacy Daszyński a kwestia oświaty robotniczej w dwudziestoleciu międzywojennym. Acta Univ. Lodziensis. Folia Historica. [Vol.] 71: Studia i szkice z historii Polski w XX w.: 2001 s. $63-77$, sum.

164. NOWARSKI Czesław: Uniwersyteckie kształcenie nauczycieli historii w okresie Drugiej Rzeczypospolitej. Annales Acad. Paedagog. Cracoviensis. Fol. 3. Studia Historica. [T.] 1: 2001 s. $203-236$, sum.

165. OLEJNIK Tadeusz: Szkolnictwo w Wieluniu w latach 1918-1939. Roczn. Wieluński. T. 1: 2001 s. $111-174$.

166. OLSZÓWKA Małgorzata, Wołczyk Urszula: Biblioteki pedagogiczne i działalność naukowa nauczycieli w województwie ślaskim $(1922$ - 1939). Katowice 2000 Wydaw. UŚ ss. 92, sum., Zsfg. Prace Naukowe Uniwersytetu Ślaskiego w Katowicach. Nr 1925. 
167. PASKUDZKA Aneta: Szkolnictwo i oświata pozaszkolna w Łukowie w latach 1918-1939. Szkice Podlaskie. Z. 8: 2000 s. 81 - 97.

168. PONCZEK Mirosław: Koncepcja, program oraz praktyczne zastosowanie kultury fizycznej w polskich katolickich organizacjach młodzieżowych II Rzeczypospolitej. W: Dyplomacja, polityka, prawo. Księga pamiątkowa ofiarowana Profesorowi Henrykowi Kocójowi w siedemdziesiąta rocznicę urodzin. Pod red. Idziego Panica. Katowice 2001 s. 350-362.

169. RADOMYSKI Stanisław: ...Podchorążych Szwadron Jazdy. Wspomnienia absolwentów Szkoły Podchorążych Rezerwy Kawalerii w Grudziądzu 1926 - 1939. Pruszków 2001 Ajaks ss. 159, nlb. 1, tabl. 8, il.

170. REĆKO Jan: Wychowanie dzieci i młodzieży w polityce rządów obozu Józefa Piłsudskiego w latach 1926-1939. Sowiniec. Nr 18: 2001 s. $101-114$.

171. RUCIŃSKI Tadeusz: Z dziejów wojskowych szkół lotniczych w Grudziądzu (1921 - 1939). Roczn. Grudziadzki. T. 14: 2001 s. $143-169$.

172. SADOWSKA Joanna: Ku szkole na miarę Drugiej Rzeczypospolitej. Geneza, założenia i realizacja reformy Jędrzejewiczowskiej. Białystok 2001 Wydaw. Uniw. w Białymstoku ss. 295, il.

173. SIEMAKOWICZ Marian: Polityka polska wobec szkolnictwa białoruskiego w okresie odbudowy państwowości polskiej. Białoruskie Zesz. Hist. Nr 15: 2001 s. 42-51, zmest.

Lata 1918 - 1921.

174. SIEMAKOWICZ M.: Szkoły z białoruskim językiem nauczania na tle polityki władz polskich wobec ludności białoruskiej w II Rzeczypospolitej (od odzyskania niepodległości do zamachu majowego 1926 r.). Białoruskie Zesz. Hist. Nr 16: 2001 s. 69-105, zmest.

175. SOBEL Grzegorz: Rola Mittelschlesien Bilderbühnenbundes w upowszechnianiu wizualnych środków dydaktycznych w nauce szkolnej w latach 1924 - 1934. Ślaski Kwart. Hist. Sobótka. R. 56: $2001 \mathrm{nr} 1$ s. $57-57$.

176. STAN oświaty i szkolnictwa w ośmiu powiatach województwa białostockiego na dzień 1 kwietnia 1936 r. [Wyd.] Marek Kietliński. Biul. Hist. Pogranicza. Nr 2: 2001 s. 79-88.

177. WASIAK Andrzej: Zarys działalności Towarzystwa Uniwersytetu Robotniczego w Częstochowie w okresie międzywojennym. Biuletyn [Inst. Filoz.-Hist. WSP w Częstochowie]. [Nr] 27: 2001 s. $243-247$.

178. WINCENCIAK Witold: Oświata łomżyńska okresu międzywojennego (1918 - 1939). Studia Łomżyńskie. T. 11: 2000 [druk.:] 2001 s. 23-45.

179. WOJCIECHOWSKI Mieczysław: Wszechnica Pomorska jest koniecznością. Memoriał Instytutu Bałtyckiego w Toruniu z 1934 roku w sprawie organizacji szkolnictwa wyższego na Pomorzu. W: W kraju i na wychodźstwie. Księga pamiatkowa ofiarowana Profesorowi Sławomirowi Kalembce w sześćdziesięciolecie urodzin. Red. nauk. Zbigniew Karpus [i in.]. Toruń-Olsztyn 2001 s. 499 - 509.

180. ZAJAC Stanisław: Z dziejów oświaty żydowskiej w Otwocku w latach 1918 - 1939. Muzeum Szkolne. Nr 47. Wkładka do czasop. Wiadom. Hist. R. 44: 2001 nr 4 s. $61-64$.

\section{Okres $1939-1945$}

181. BUJANOWSKA Beata: Walka o przetrwanie. Życie codzienne dzieci polskich w Kazachstanie w latach 1940 - 1942. Acta Univ. Lodziensis. Folia Historica. [Vol.] 73: Z zagadnień historii XX wieku: 2001 s. $67-81$, sum. 
182. DRAUS Jan: Polskie Seminarium Duchowne w Bejrucie 1943-1946. W: Jezuicka ars historica. Prace ofiarowane Księdzu Profesorowi Ludwikowi Grzebieniowi SJ. Red. Marek Inglot, Stanisław Obirek. Kraków 2001 s. $135-152$.

183. DZIUROK Adam: Stracenie gotartowickich harcerzy w 1942 roku. Biul. Inst. Pamięci Nar. Nr 10: 2001 s. $17-18$.

184. FILIPKOWSKI Tadeusz: Straty szkolnictwa polskiego na Kresach Wschodnich (1939 - 1945). W: W kraju i na wychodźstwie. Księga pamiatkowa ofiarowana Profesorowi Sławomirowi Kalembce W sześćdziesięciolecie urodzin. Toruń-Olsztyn 2001 s. 511 - 519.

185. GŁOWACKI Albin: Przesiedlenie dzjeci z Polskich Domów Dziecka w Komi ASRR do obwodu tambowskiego w 1944 r. My, Sybiracy. Nr 12: 2001 s. 19-30.

186. GRZADZZIELSKI Zbigniew: Był taki czas... Okupacyjne epizody Częstochowy i powiatu częstochowskiego w latach 1939-1945. Biuletyn [Inst. Filoz.-Hist. WSP w Częstochowie]. [Nr] 27: 2001 s. $5-161$.

Zawiera również wspomnienia nauczycieli w opracowaniu autora.

187. GRZELAKOWSKA Elżbieta, Pietras Tomasz, Walenta Gabriela: „W szkołach, których nie było...". Sprawozdanie z rocznicowej wystawy w Muzeum Oświaty Łódzkiej. Roczn. Lódzki. T. 47: 2000 s. $245-250$.

Tajne nauczanie w województwie łódzkỉm w czasie II wojny światowej; X-XI 1999 r.

188. JAROWIECKI Jerzy: „Przeglad Polski” (1940-1944) - konspiracyjne pismo Szarych Szeregów w Krakowie. Roczn. Hist. Prasy Pol. T. 4: 2001 z. 1 s. $63-91$, sum., streszcz.

189. KOŁODZIEJ Wincenty: Oświata w polskim państwie podziemnym. Krakowskie Studia Matopolskie. Nr 4: 2000 s. $263-265$.

190. KRZYŻANOWSKI Lech: Straty osobowe nauczycielstwa górnośląskiego na tle losów inteligencji polskiej województwa ślaskiego podczas drugiej wojny światowej. W: Wrzesień 1939 roku i jego konsekwencje dla ziem zachodnich i północnych Drugiej Rzeczypospolitej. Studia pod red. Ryszarda Studzińskiego i Włodzimierza Jastrzębskiego. Toruń-Bydgoszcz 2001 s. 233-348.

191. KUREK Ewa: Dzieci żydowskie w klasztorach. Udział żeńskich zgromadzeń zakonnych w akcji ratowania dzieci żydowskich w Polsce w latach 1939-1945. Lublin 2001 Clio ss. 272.

192. MAŁECKI Andrzej R.: Trudna pamięć. Krakowscy i wrocławscy akademicy na Wzgórzach Wuleckich we Lwowie. Alma Mater. Nr 33: 2001 s. 21 - 23.

Dor. egzekucji profesorów lwowskich d. $3 / 4$ lipca 1941 r.

193. ODCZYK Henryk: Podchorążówka o Oddziale „Żbika”. W: Pamięci Narodowych Sił Zbrojnych we Włoszczowskiem. Rada Konsultacyjna Stefan Kapelusz [i in.]. Włoszczowa 2001 s. 42 - 43.

194. OLESIAK Zbigniew S.: O lwowskim środowisku akademickim podezas wojny. Kwart. Hist. Nauki i Techn. R. 46: 2001 nr 2 s. $35-63$, sum.

195. PAWLIK Jerzy: Wspomnienia o Seminarium Duchownym. Ziemia Ślaska. T. 5: 2001 s. $105-113$.

O polskich alumnach ze zlikwidowanych seminariów w Katowicach i Krakowie w 1. 1939-1942.

196. PRZEZ burze pod wiatr. Szkolnictwo i oświata polska na Zachodzie w czasie drugiej wojny światowej. Układ, oprac. i red. nauk. Teresa Zaniewska. Białystok 2001 Trans Humana ss. 339, nlb. 4, tabl. 8, il.

Materiały z międzynarodowej konferencji, Ciechanowiec 5-7 września $2000 \mathrm{r}$.

Z treści: Prugar-Ketling Zygmunt: Wstęp s. 13-18; Kobryner Jan: Nauka dla Polski. Praca dla Szwajcarii. Szkolnictwo poiskie w Szwajcarii 1940 - 1945. Cele. Zasady. Organizacja. Program s. 19 - 37; Smoliński Józef: Polskie obozy uniwersyteckie w Szwajcarii w czasie drugiej wojny światowej s. 38 - 51 ; Raszkiewicz Henryk: Józef Innocenty 
Maria Bocheński - humanistyczna wartość umysłu logicznego s. 52-74; Pruszyńska Agnieszka: Żołnierze-studenci medycyny w Szwajcarii, Libanie i we Włoszech w latach 1940-1951; Rużylło Edward: Powstanie i działalność Polskiego Wydziału Lekarskiego na Uniwersytecie w Edynburgu s. 88 - 105; Niemialtowski Marek: Wspomnienie o doc. dr med. doktorze honoris causa Wiktorze Tomaszewskim, strażniku pamięci Polskiej Szkoły Medycznej w Edynburgu (194l-1949) s. 106-108; Chazbijewicz Selim: Działalność polityczna, religijna, oświatowa i wychowawcza Naczelnego Imamatu Polskich Sił Zbrojnych na Zachodzie w latach 1942 - 1990 s. 109 - 119; Zaniewska Teresa: Działalność oświatowa porucznik Dżennet Dżabagi-Skibniewskiej. „Dziatwa” $1944-1946$ s. 120-142; Romanowska Ewa: Wartości patriotyczno-edukacyjne „Naszego Pisemka” [1941-1944] z Castlemains s. 143 - 155; Matwiejczyk Marek: Działalność kulturalno-patriotyczna Janusza Meissnera s. 156-165; Pietruski Jan: Leopold Kielanowski [1907-1988] - Wielki zapomniany s. 166-174; Walasek Stefania: Szkolnictwo polskie poza granicami II Rzeczypospolitej w latach 1939 - 1945 (Bliski i Środkowy Wschód, Afryka) s. 175-186; Dobroński Adam [Czesław]: Junackie Gimnazjum Kupieckie w Nazarecie [1945-1947] s. 187 -200; Radomska Maria: Szkoła Junaczek i Szkoły Mlodszych Ochotniczek w Armii Polskiej na Wschodzie s. 201 - 218; Taż: Kurs maturalny oraz Gimnazjum i Liceum dla Ochotniczek PSK 2. Korpusu 1945-1948 s. 219-240; Dobrowolska-Sosnowska Katarzyna: Działalność opiekuńczo-wychowawcza Hanki Ordonówny s. 241 -255; Kamińska Janina: Tradycje ksztalcenia polonijnego we Francji s. 256-266; Kleczkowski Mirosław, Romanowska E.: Polska emigracja a rozwój francuskiego rolnictwa s. $267-272$.

197. REZLER-WASIELEWSKA Violetta: Działalność naukowo-oświatowa polskich jeńców wojennych $w$ niemieckich i radzieckich obozach podczas II wojny światowej. Łambinowice - Opole 2001 CMJW ss. 264, tabl. 12, il., sum., Zsfg. Centralne Muzeum Jeńców Wojennych w Łambinowicach - Opolu.

198. REDZIŃSKI Kazimierz: Oświata i szkolnictwo polskie we Lwowie w latach 1939-1941. W: Przyzywanie głębi do kręgu słów, myśli, idei i działań. Księga jubileuszowa ofiarowana Profesorowi Józefowi Żurawowi. Pod red. Stanisława Podobińskiego i Bogdana Snocha. Częstochowa $1999-2000-2001$ s. $701-711$.

199. STERKOWICZ Czeslaw: Szkolnictwo jawne i tajne w powiecie tamowskim w latach 1939- 1945. Tarnów 2001 Tarnowskie Tow. Kult.; Muzeum Okręg. ss. 241, nlb. 7, il.

200. STOPIKOWSKA Małgorzata: Wychowanie Polaków na zesłaniu w ZSRR. Lublin 2001 Red. Wydawnictw KUL ss. 286, nlb. 1. Katolicki Uniw. Lubelski. Wydz. Teologii.

201. ŚLESZYŃSKI Wojciech: Władze szkolne i kadra pedagogiczna w sowieckim modelu oświaty na obszerze przedwojennego województwa białostockiego w latach 1939-1941. Białoruskie Zesz. Hist. Nr 16: 2001 s. $128-140$, zmest.

202. WALCZAK Marian: Lwów i Wilno - edukacja dzieci polskich w latach 1939-1945. Warszawa-Radom 2001 Inst. Technologii Eksploatacji ss. 43, nlb. 1.

203. WALCZAK M.: Straty materialne i szkody moralne szkolnictwa polskiego $w$ okresie okupacji 1939-1945. Radom 2001 Wydaw. i Zakład Poligrafii Inst. Technologii Eksploatacji ss. 107, il., mapy.

\section{Okres $1945-1989$}

204. BRENDA Waldemar: Konspiracja młodzieżowa w Pasłęku i Moragu w latach 1951 - 1954. Zesz. Hist. WiN-u. R. 10: 2001 nr 16 s. $57-70$.

205. BROCHOCKI Jerzy: Rewolta Marcowa. Narodziny, życie i śmierć PRL. Warszawa 2001 Placówka ss. 366 , tabl. 18 , il.

Toż. Wyd. 2. Warszawa 2001 Rota ss. 367, tabl. 18, il.

206. CHMIELEWSKI Zdzisław: Od Szkoły Handlowej do Uniwersytetu Szczecińskiego - obecność szkół wyższych w intelektualnych przeobrażeniach Szczecina po 1945 r. Roczniki [Stacja Nauk. PAN w Paryżu]. T. 4: 2001 s. $31-39$. 
207. CHMIELEWSKI Z.: Zachodniopomorskie szkoły wyższe w Gierkowskiej dekadzie. W: Lata 1970 - 1980. Nowe perspektywy a realia na Pomorzu Zachodnim. Pod red. Henryka Komarnickiego i Kazimierza Kozłowskiego. Szczecin 2001 s. 53-65.

208. CONNELLY John: Captive university. The sovietization of East German, Czech and Polish higher education, 1945-1956. Chapel Hill 2000 Univ. of North Carolina Press ss. XVIII, 432.

209. DOMAGAŁA Bożena: Próby przekształcenia świadomości Mazurów i Warmiaków we wspomnieniach uczestników Mazurskiego Uniwersytetu Ludowego w Rudziskach Pasymskich. W: Wysiedlać czy repolonizować? Dylematy polskiej polityki wobec Warmiaków i Mazurów po 1945 roku. Praca zbiorowa. Pod red. Tadeusza Filipkowskiego i Witolda Gieszczyńskiego. Olsztyn 2001 s. 63 - 76.

210. GIEROWSKI Józef Andrzej, Pułaski Michał: Likwidujemy „białe plamy”. Czym dla Uniwersytetu Jagiellońskiego była „Solidarność”?. Alma Mater. Nr 27: 2000/2001 [druk.:] 2001 s. $43-44$.

211. GRZYBOWSKI Romuald: Wyższe szkoły pedagogiczne w Polsce w latach 1946 - 1956. Gdańsk 2000 Akad. Wychowania Fizycznego ss. 426.

212. HŁADKIEWICZ Wiesław, Mazurkiewicz Piotr: Polski ruch naukowy i akademicki w zachodnich strefach okupowanych Niemiec (1945 - 1949). W: Nauka polska na obczyźnie. Stan i perspektywy badawcze. Konferencja naukowa Il - 12 września 1998 r. w Zielone Górze. Red. Wiesław Hładkiewicz, Marek Szczerbiński. Gorzów Wlkp. 2000 s. 64-70.

213. JASIŃSKA Hanna: XXV lat działalności Klubu Sportowego przy Pałacu Młodzieży w Bydgoszczy. Kronika Bydgoska. T. 22: 2000 [druk.:] 2001 s. $282-291$.

214. JEDDRZEJCZYK Wacław J.: W Polskiej Szkole DP w Niemczech po drugiej wojnie światowej Wspomnienia ucznia z lat 1945-1949. Archiwum Emigracji. Z. 3: 2000 s. $278-284$.

215. KACHNICZ Zenon: Młodzież w konspiracji antykomunistycznej na przykładzie działającej po drugiej wojnie światowej na Pomorzu Polskiej Organizacji Wojskowej (POW). Przegl. Zachodniopomorski. T. 16: 2001 z. 1 s. $87-103$.

216. KA£A Monika: II ogólnopolska sesja naukowa „Młodzież w oporze społecznym 1944-1989". Biul. Inst. Pamięci Nar. Nr 6: 2001 s. $52-55$.

Wroclaw, 3-4 V $2001 \mathrm{r}$.

217. KOWALAK Czesław: Bitwa legnicka w polskich podręcznikach historii po 1945 r. Szkice Legnickie. T. 22: 2001 s. 87-102.

218. KOŹMIAN Danuta: Problemy szkolnictwa podstawowego w województwie szczecińskim na lamach „Głosu Szczecińskiego” w latach 1970 - 1980. W: Lata 1970 - 1980. Nowe perspektywy a realia na Pomorzu Zachodnim. Pod red. Henryka Komarnickiego i Kazimierza Kozłowskiego. Szczecin 2001 s. $179-196$.

219. LECZYCA. Monografia miasta do 1990 roku. Red. Ryszard Rosin. Łẹczyca 2001 TNP ss. 824, tabl. 30, il., mapy. Oddz. Tow. Nauk. Płockiego w Łęczycy; Tow. Miłośn. Ziemi Łęczyckiej.

Z tresci: Wójcik Henryk: Oświata w latach $1945-1990$ s. 579-611.

220. MARTEŃCZYK Ałła: Na batiuszkę poszedł. Przegl. Prawosławny. [R. 17]: 2001 nr 6 s. $14-17$.

Wspomnienia z 1. 1951-1970 o Prawosławnym Seminarium Duchownym w Warszawie.

221. ODZIEMKOWSKI Janusz: By pomóc młodzieży. Prymas Stefan Wyszyński wobec problemu wychowania młodego pokolenia w Polsce. W: Polska Prymasa Wyszyńskiego. Materiały z sesji naukowej zorganizowanej w ramach obchodów roku Prymasa Stefana Wyszyńskiego, Tarnów 26.04.2001 r. Red. Bogusław Wójcik. Tarnów 2001 s. 19-41. 
222. PASZTOR Maria, Jarosz Dariusz: Kolonie dla dzieci polonijnych jako instrument polskiej polityki zagranicznej w latach 1947 - 1956. Mazowieckie Studia Humanist. R. 7: 2001 nr I s. 5-31.

223. PATRO Gustawa: Poczatki i rozwój szkolnictwa powszechnego w powiecie wągrowieckim w latach 1945-1948. Wagrowiec 2001 J\&T Belfer ss. 131, nlb. 1, il., mapy.

224. PERKOWSKA Urszula: Studenci Uniwersytetu Jagiellońskiego z lat 1945 - 1952 w powojennej opozycji antykomunistycznej. Roczn. Krakowski. T. 67: 2001 s. $127-142$, sum.

225. PERKOWSKA U.: Wrogie wystapienia w czasie zawieszania... Stosunek studentów Uniwersytetu Jagiellońskiego do władzy ludowej w świetle orzeczeń Komisji Dyscyplinarnej z poczatku lat pięćdziesiątych. Alma Mater. Nr 31: 2001 s. $27-28$.

226. SECZYK Waldemar: Obraz Marca '68 na Dolnym Śląsku w prasie lokalnej. Ślaski Kwart. Hist. Sobótka. R. 56: 2001 nr 1 s. 87-98.

227. SIKORSKI Juliusz: Bitwa o młode pokolenie. Z problematyki laicyzacji dzieci i młodzieży w Gorzowie w latach 1945 -56. Nadwarciański Roczn. Hist.Archiw. T. 8: 2001 s. 149-185.

228. SIWKO Maria: Wzory osobowe w polskiej prasie młodzieżowej okresu przelomu (na przykładzie „Sztandaru Młodych” - 1979 - 1982 i „Filipinki” - 1988 - 1989). Koszalin 2001 Wydaw. Uczelniane PK ss. 161, nlb. 2. Politech. Koszalińska. Monografie Wydziału Ekonomii i Zarządzania. $\mathrm{Nr} 78$.

229. SKOBELSKI Robert: Akcja likwidacji analfabetyzmu na terenie województwa zielonogórskiego w latach 1949-1951. Roczn. Lubuski. T. 27: 2001 cz. 2 s. $143-155$.

230. ŚWIEYKOWSKA-JASIŃSKA Barbara: Migawki pamięci. Wspomnienia studentki Wydziału Prawa UJ w latach 1945-49. Alma Mater. Nr 27: 2000/2001 [druk.:] 2001 s. 33-37.

231. TERLECKI Ryszard: Uniwersytet Latający i Towarzystwo Kursów Naukowych 1977 - 1981. Kraków-Rzeszów 2000 Inst. Europejskich Studiów Społ.; Poligrafia Wyższego Seminarium Duchownego w Rzeszowie ss. 327.

Rec.: Lasota Marek, Zesz. Hist. WiN-u. R. 10: 2001 nr 15 s. 298-299.

232. TUREK-KWIATKOWSKA Lucyna: Gospodarka a oświata szczecińska w latach 1970 - 1980. W: Lata 1970-1980. Nowe perspektywy a realia na Pomorzu Zachodnim. Pod red. Henryka Komarnickiego i Kazimierza Kozlowskiego. Szczecin 2001 s. $139-150$.

233. UZIEMBEO Adam: Wspomnienia z Ministerstwa Oświaty (rozmowy z Aleksandrem Leinwandem). Do dr. przygot. Aniela Uziemblo. Zesz. Hist. Z. 137: 2001 s. 76-94.

Lata 1947 - 1949.

Sprost:: Uziemblo A., Tamze. Z, 138: 2001 s. 223.

234. WERBIŃSKI Ireneusz: Z dziejów Fundacji im. Jadwigi Kilaczyckiej w Londynie. Studia Wloctawskie. T. 4: 2001 s. $53-68$, sum.

Stypendia dla studentów teologii, od $1981 \mathrm{r}$.

235. WOJDON Joanna: Propaganda polityczna w podręcznikach dia szkół podstawowych Polski Ludowej (1944-1989). Toruń 2001 Wydaw. Adam Marszałek ss. 329, il.

236. WRONA Janusz: Aparat bezpieczeństwa wobec wystąpień i strajku młodzieży szkolnej i studentów w Lublinie w 1947 roku. Res Historica. Z. 11: 2000 s. 163-176.

237. ŻUREK Jacek: Edukacja ateistyczna w PRL. (Geneza i charakter zjawiska). Arcana. Nr 38: 2001 s. $85-94$. 


\section{Okres $1989-2001$}

238. DĄBROWA-SZEFLER Małgorzata: Szkoły wyższe w dziesięcioleciu 1991 - 2000 a polityka edukacyjna państwa. Nauka Pol. - Jej Potrzeby, Organizacja i Rozwój. [T.] 10 (35): 2001 s. 18 -28.

239. MATERNICKI Jerzy: Studia historyczne w Polsce. Główne kierunki reform po $1989 \mathrm{r}$. Wiadom. Hist. R. 44: 2001 nr 4 s. $220-226$.

240. SKRZYŃSKA Barbara: Rozwój szkolnictwa wyższego na Śląsku Opolskim w latach 1990-2000. Opolskie Roczniki Ekonom. T. 16: 2001 s. 37-152.

241. WRÓBLEWSKA Małgorzata: Szkolnictwo wyższe w województwie opolskim w latach 1989 - 1999. Opole 2001 Wydaw. Inst. Śląski ss. 72, nlb. 2, il. Politech. Opolska. Wydz. Zarządzania i Inżynierii Produkcji.

242. ŻYROMSKI Marek: Reforma oświaty a konflikty społeczno-polityczne w III Rzeczypospolitej. W: Konflikty społeczno-polityczne w III Rzeczypospolitej. Pod red. Andrzeja Wojtasa i Michała Strzeleckiego. Warszawa 2001 s. $185-191$.

\section{Oświata polonijna}

243. BONUSIAK Andrzej: Dzieje polskiego szkolnictwa sobotniego w metropolii chicagowskiej 1951 - 1997. Przemyśl 2001 Mercator ss. 330, tabl. 16, il., mapa, sum.

244. BONUSIAK A.: Zarys dziejôw Zrzeszenia Nauczycieli Polskich w Ameryce z siedziba w Chicago (1952-2000). Przegl. Polonijny. R. 27: 2001 z. 2 s. 49-64, sum.

245. GRZYWACZEWSKI Józef: Polskie seminarium w Paryżu. Roczniki [Stacja Nauk. PAN w Paryżu]. T. 4: 2001 s. $197-202$.

Lata $1945-2000$.

246. MISCELLANEA oświaty polonijnej. Pod red. Jacka Knopka. Bydgoszcz 1999 [druk.:] 2000 Przedsiębiorstwo Usługowo-Handlowe „Reklamex”; Wydaw. Inst. Nauk Polit. WSP Bydgoszcz ss. 170, nlb. 5, sum. Bydgoskie Studia Narodowościowe i Polonijne. T. 1.

Materiały 2 konferencji naukowej, Bydgoszcz, 29 kwietnia $1999 \mathrm{r}$.

Treść: Knopek J.: Wprowadzenie s. 5-6; Mieczkowski Janusz: Ewolucja szkolnictwa dla mniejszości narodowych w Polsce w latach 1944-1989 s. 7-15; Chodubski Andrzej: Aktualne tendencje rozwoju oświaty polonijnej s. 17-30; Kolodziej Edward: Harcerstwo polskie we Francji, Belgii i Holandii w latach międzywojennych i jego miejsce w systemie oświaty polonijnej s. 31 -44; Skóra Wojciech: Oświata polonijna w Szczecinie w świetle dokumentów MSZ Drugiej Rzeczypospolitej s. 45-67; Chodubski A.: Swoistość współczesnej oświaty polonijnej w Holandii s. 69 - 80; Olszewski Edward: Polska Szkoła Sobotnia im. Jana Pawla II w Oslo s. 81 - 101; Kaczmarek Urszula: Oświata polonijna na Wegrzech s. 103 -114; Knopek J.: Przeobrażenia współczesnej oświaty polonijnej w Grecji s. 115 - 145; Żukowski Arkadiusz: Model oświaty polonijnej w Republice Południowej Afryki - kontynuacja tradycji czy nowatorstwo s. 147 -156; Knopek J.: Problematyka oświaty w skupiskach polonijnych północnej części Afryki s. 157-170; Knopek Dorota: Wykaz publikacji książowych dotyczących oświaty polonijnej s. $171-172$.

247. MOLENDA Kazimierz: Marzy mi się szkoła... Rozmowa z Kazimierzem Molenda, prezesem Stowarzyszenia Byłych Uczniów Liceum Polskiego w Paryżu (Amicale des Anciens Eleves du Lycée Polonais de Paris). Roczniki [Stacja Nauk. PAN w Paryżu]. T. 4: 2001 s. 191-196.

Z okazji przypadajacego w 2002 r. 160-lecia Szkoły Batignolskiej i 35-lecia „Amicale...”.

248. ORGANIZACJE polonijne. Dzieje, współczesność i perspektywy. Konferencja naukowa 24 - 25 czerwca 1997 r. w Rogach koło Gorzowa Wlkp. Red. Marek Szczerbiński. Gorzów Wlkp. 2001 RPBnP ss. 174, il. Prace Naukowe Rady Porozumiewawczej Badań nad Polonią. Materiały z Konferencji. T. 2. 
Z treści: Kołodziej Edward: Harcerstwo polskie w Beigii w latach międzywojennych s. 75-83; Olszewski Edward: Z dziejów Zwiazku Harcerstwa Polskiego w Danii (1926-1996) s. 85-98; Kliszewicz Leonidas, Witting Jerzy: Z dziejów Zwiazku Harcerstwa Polskiego poza granicami Kraju s. 99-102; Kliszewicz L.: Przegląd publicystyki metodyczno-programowej i historycznej Zwiazku Harcerstwa Polskiego poza granicami Kraju w latach 1939 - 1998 s. 103 - 108; Witting J.: Oganizatorzy i wybitni działacze Związku Harcerstwa Polskiego poza granicami Kraju s. 109-116; Kiewlak Wiesław: Udzjal harcerstwa w odrodzeniu świadomości narodowej polskiej młodzieży na Białorusi s. 117-119; Szymeczek Józef: Działalnośc Harcerstwa Polskiego w Republice Czeskiej (1989-1998)

s. 121 - 131; Kurzępa Jacek, Gasztoł Mariusz: Historia Harcerstwa Polskiego na Litwie s. 133 - 142.

249. OSIPOWICZ Czesława: Szkolnictwo polskiej mniejszości narodowej na Litwie. W: Polacy i Polonia u progu nowego tysiąclecia. II Zjazd Polonii i Polaków z Zagranicy, 28 kwietnia - 3 maja 2001 r. Warszawa-Pułtusk-Kraków-Częstochowa. Referaty. Red. Jolanta Wroczyńska. Warszawa 2001 Stow. „Wspólnota Polska” s. $143-154$.

250. ROMEJKO Adam: Polskie szkolnictwo katolickie i ośrodki wychowawcze w Wielkiej Brytanii. Studia Gdańskie. T. 14: 2001 s. $201-235$, Zsfg.

XIX - XX w.

251. WYRWA Tadeusz: Założenia Uniwersytetu Polskiego Zagranica w Paryżu w 1939 r. W: Dyplomacja, polityka, prawo. Księga pamiątkowa ofiarowana Profesorowi Henrykowi Kocójowi w siedemdziesiąta rocznicę urodzin. Pod red. Idziego Panica. Katowice 2001 s. 370-374.

\section{DZIEJE SZKÓE RÓŻNYCH STOPNI}

\section{Szkoły podstawowe i zakłady wychowawcze}

252. BACHTA Eugeniusz: Dzieje Szkoły Podstawowej w Bajdach (ok. 1909-1999) z krótką historia wsi. Krosno 2001 Apla ss. 116, tabl. 8, il.

253. DOROBISZ Jolanta: Szkoła starsza od miasta. Muzeum Szkolne. Nr 45. Wkładka do czasop. Wiadom. Hist. R. 44: 2001 nr 2 s. $28-31$.

Szkoła Podstawowa nr 18 w Sosnoweu, XIX-XX w.

254. DZIEJE i rozwój Szkoły Podstawowej nr $1 \mathrm{im}$. Tadeusza Koóciuszki w Andrychowie 1791 - 2001. Kolegium red. Jadwiga Stawarz [i in.]. Andrychów-Tomice 2001 SCAL-bis ss. 139, tabl. 8 , il.

255. GMINA Batorz w przeszłości i dzisiaj. Krosno 2001 Gminny Ośr. Kultury w Batorzu; Apla ss. 132, tabl. 12, il., mapa.

Z treści: Mazur Anna: Szkoła w Batorzu s. 99-102; Grela Marian: Publiczne Gimnazjum w Batorzu s. 102 - 103; Bartnik Anna: Szkoła Podstawowa w Aleksandrówce s. 103 - 108; Jaworska Bożena: Szkoła w Błażku s. 108 - 111.

256. JASIŃSKI Grzegorz: Dom sierot im. Friedricha Ballnusa w Olecku - przykład zakładu opiekuńczego na Mazurach w XIX wieku. Komunikaty Mazur.-Warm. [R. 45]: $2001 \mathrm{nr} 1 \mathrm{~s} .33$ - 46, Zsfg.

257. KARPIŃSKI Edward: Zarys historii szkoły w Olesznie do roku 1945. Wloszczowskie Zesz. Hist. R. 6: 2001 t. 11 s. $100-113$.

$\mathrm{XIX}-\mathrm{XX}$ w.

258. KOŻUCH Krystyna: Historia szkoły w Woli Osowińskiej. W: ...bo tu mój dom. Wola Osowińska dawniej i dziś. W oprac. Krystyny Kożuch. Wola Osowińska-Lublin 2001 s. $43-70$.

259. KRONIKA Szkoły Ludowej we Wrocance: 1878 - 1942. Oprac. i wyd. Józef Marecki. Kraków 2001 Format ss. 221, nlb. 2, tabl. 24.

260. KRONIKA szkoły w Olesznie $1930-1971$. Do dr. podał i wprowadzeniem poprzedził Stanisław Janaczek. Wloszczowskie Zesz. Hist. R. 6: 2001 t. 11 s. 235-271. 
261. MARCIAK-KOZŁOWSKA Janina: Ochronka Sióstr Służebniczek NMP w Duńkowicach. By czas nie zaćmił i niepamięć... Warszawa-Duńkowice 2001 Janina Marciak-Kozłowska ss. 52, tabl. 6, il.

$\mathrm{XX}$ w.

262. MOMOT Lucjan: Od kary chłosty do kary nagany. Szkic do dziejów Zakładu Poprawczego i Schroniska dla nieletnich w Świdnicy 1802 -1999. Roczn. Świdnicki. T. 28: 2001 s. 104-115.

263. PAWŁOWSKA Teresa: Sierpecka szkoła w starej fotografii i dokumencie. Kalendarium 1871 - 1985. Sierpc 2001 Teresa Pawłowska ss. 127, tabl. 4, il., mapa.

264. PIATKOWSKI Sebastian: Szkoła elementarna w Janowcu w latach 1809 - 1914. Janowiec 2001 Tow. Przyj. Janowca ss. 113. Małe Monografie Janowieckie. [Z.] 2.

265. SZKOŁA w Dąbrowie. Wczoraj i dziś. Praca zbiorowa. Pod red. Adama Orczyka. Radom 2001 Ave ss. 143, tabl. 15, il.

266. WOJCIECHOWSKI Piotr: Historia Szkoły Podstawowej im. Hansa Christiana Andersena w Karsku, woj. zachodniopomorskie. Cz. 2: Lata 1961 - 1991. Nadwarciański Roczn. Hist.-Archiw. T. 8: 2001 s. $191-210$.

Cz. 1. Tamże. T. 7: 2000 t. 1.

\section{Szkoły średnie ogólnokształcące}

267. ACHREMCZYK Stanisław: Uczniowie Prus Książęcych w toruńskim gimnazjum akademickim 1600-1817. Komunikaty Mazur.-Warm. [R. 45]: 2001 nr 3 s. 419-421.

268. BORZYMIŃSKA Zofia: Wspomnienia o przeszłości czyli historia Prywatnego Koedukacyjnego Gimnazjum Towarzystwa Szkół Żydowskich w Międzyrzecu Podlaskim. Roczn. Międzyrzecki. T. 31/32: 2001 s. $193-197$.

Lata $1917-1939$.

269. CHOJECKI Ryszard: Liceum Ogótnokształcące w Łosocicach (1944 - 2000). Podlaski Kwart. Kult. 2001 [nr] $3 / 4$ s. $23-34$.

270. DZIEJE zachwytu, czyli rzecz o szkole. Praca zbiorowa. Pod red. Aleksandry i Jacka Kurków. Chorzów 2000 Rococo ss. 271, il.

IIl Liceum Ogólnoksztalcące im. Stefana Batorego w Chorzowie.

271. GRZYBOWSKI Michał Marian: Prekursorzy łowickiej uczelni. Mazowieckie Studia Humanist. R. 6: $2000 \mathrm{nr}$ 1/2 [druk.:] 2001 s. $135-137$.

Szkola kolegiacka w Łowiczu XV-XVII i Kolegium Pijarów w Łowiczu w l. 1670-1831.

272. KAPERA Józef Z:: Z dziejów Liceum Ogólnokształcącego „Carolinum” w Nysie. Muzeum Szkolne. Nr 44. Wkładka do czasop. Wiadom. Hist. R. 44: 2001 nr 1 s. $13-16$.

$\mathrm{XIX}-\mathrm{XX}$ w.

273. KAPROŃ Andrzej: Cudzoziemscy nauczyciele gimnazjum lubelskiego w latach $1815-1915$. Lublin 2001 Norbertinum ss. 44, nlb. 1.

I Liceum Ogólnokształcace im. Stanisława Staszica w Lublinie.

274. KAWECKI Wojciech: Gimnazjum Męskie im. Św. Stanisława Kostki w Warszawie 1908 - 1944. Warszawa 2001 Agencja Reklamowo-Wydawnicza Arkadiusz Grzegorczyk ss. 389, il.

Zawiera także wspomnienia uczniów.

275. KESEK Janina: Bursa gimnazjalna i kościół szkolny w Bochni. Roczn. Bocheníski. T. 5: 2001 s. $197-224$.

Lata $1886-2000$. 
276. KIEZIK Ewa: Pedagogiczny wymiar działalności Szkolnego Koła Krajoznawczo-Turystycznego przy I LO w Giżycku (w latach 1964 - 1999). Giżycko 2000 Zarzad Oddz. PTTK Wielkich Jezior Mazurskich ss. 144, tabl. 12, il.

277. KOPYCIŃSKI Jan, Kopycińska Aldona: Dzieje I Liceum Ogólnoksztalcacego w Nowogardzie. Muzeum Szkolne. Nr 47. Wkładka do czasop. Wiadom. Hist. R. 44: 2001 nr 4 s. $51-55$.

Lata $1945-1969$.

278. KSIĘGA pamiątkowa liceum ogólnokształcącego w Ustrzykach Dolnych 1951 - 2001. Zespół red. Andrzej Szczerbicki [i in.]. Ustrzyki Dolne 2001 Zespół Szkół Ogólnokształcących im. J. Pitsudskiego ss. 277, tabl. 16, il.

279. LICEUM Ogólnokształcace im. Bohaterów Westerplatte w Jabłonce 1951 - 2000. Praca zbior. pod red. Emila Janowiaka. Jabłonka-Kraków 2001 Tow. Słowaków w Polsce ss. 343, il., mapa.

280. MROWCA Bogusława, Piotrowska Olga: Nasz Staszic. Zarys historii I LO im. Stanisława Staszica w Chrzanowie. Chrzanów-Trzebinia 2001 „Przełom” Alicja Molenda ss. 172, il.

$\mathrm{XX} w$.

281. PAMIETNIK zlotu wychowanków kaliskich szkół średnich, Kalisz - 2000. Oprac. i red. Hubert Stanisław Pałęcki oraz Gustaw Elbl. Kalisz 2001 Edytor ss. 175, il.

282. [PIÉĆDZIESIAT pięć] 55 lat Liceum Ogólnokształcącego im. Mikołaja Kopernika w Solcu Kujawskim. Oprac. Bernard Białecki; współpr. Barbara Bambrowicz, Bożena Sobieralska, Edward Szymkowiak. Solec Kujawski 2001 TMSK ss. 120, il. Tow. Miłośn. Solca Kujawskiego. Zeszyty Historyczne Towarzystwa Miłośników Solca Kujawskiego. Z. 5.

283. [PIĘĆDZIESIĘCIOLECIE] 50-lecie Liceum Ogólnokształcącego im. Stefana Żeromskiego w Bielsku-Białej. Przygot. materiały do publikacji Jadwiga Jóźwiak, Izabela Podlewska-Laser, Aleksandra Pękala. Bielsko-Biała 2001 Agencja Reklamowa „Poran” ss. 159, nlb. 1, il.

284. POLUSZAŃCZYK-OKSYTIUK Ewa: Z dziejów najstarszej szkoły średniej we Włodawie. Zesz. Muzeum Pojezierza Lęczyńsko-Wlodawskiego. T. 11: 2001 s. 51-58.

LO, dawniej Prywatne Gimnazjum Koedukacyjne ogólnokształcacego Towarzystwa Szkoły Średniej; Od 1936 r.

285. RAFIŃSKI Stefan: Z dziejów gimnazjum i liceum ogólnokształcącego w Chełmnie. Bydgoszcz 2001 Bydgoskie Tow. Nauk. ss. 142, tabl. 10, i1., Zsfg.

$\mathrm{XIX}-\mathrm{XX}$ w.

286. RATAJCZAK Tomasz: Rozprawy humanistyczne w Sprawozdaniach szkolnych wadowickiego gimnazjum. Rekonesans. Wadoviana. Nr 6: 2001 s. $45-56$.

Z l. $1876-1921$.

287. SIEMION Ignacy Z.: Wokół nauczania chemii w Akademii Połockiej. Analecta. R. 10: 2001 nr 2 s. $67-79$, sum.

Istniała w 1. $1580-1820$.

288. SKWARA Jerzy: Pół wieku temu zamknięto „Jacka”. Ślask. 2000 nr 6 s. $42-44$.

Prywatne Gimnazjum i Liceum Katolickie Męskie im. św. Jacka w Katowicach.

289. SŁOKA Robert: Z dziejów I Liceum Ogólnokształcącego im. T. Kościuszki w Starachowicach. Muzeum Szkolne. Nr 47. Wkładka do czasop. Wiadom. Hist. R. 44: 2001 nr 4 s. 56-61.

Lata $1936-1945$.

290. SZKOEY Sióstr Boromeuszek i Il Liceum Ogólnokształcące przy ulicy Grunwaldzkiej w Łańcucie. Teksty historyczno-wspomnieniowe 1901 -2001. Oprac. zespół. Łańcut 2001 II Liceum Ogólnokształcące ss. 204, nlb. 1, il.

Z treści: Nitkiewicz Maria: Poczatki szkoły. Lata 1878-1917 s. 5-14: Paterak Agnieszka: Działalność pedagogiczno-wychowawcza Sióstr Boromeuszek w Łańcucie w latach 1914-1949 s. 15-31; Baran Anna: Il Liceum 
Ogólnokształcące w świetle protokołów Rady Pedagogicznej z lat 1949-2001 s. 32 -37; Lis Stanisław: Wspomnienia nauczycieli i absolwentów s. 38-83; Wykaz dyrektorów i nauczycieli Seminarium Nauczycielskiego, Gimnazjum i Liceum Zgromadzenia Sióstr Boromeuszek oraz II Liceum Ogólnokształcącego w Łańcucie w latach 1921 - 2001 s. 84 -95: Wykaz absolwentów z lat 1917-2000. Oprac. Barbara Kumorek i Anna Śliż s. 96-141.

291. TRYNKOWSKI Jan: Gimnazjum białostockie w XIX w. Wspomnienia i wiersze. Bibliotekarz Podlaski. Nr 1: 2000 s. 24-39.

292. W STULECIE szkół handlowych i ekonomicznych w Białymstoku. Złota księga wspomnień. Praca zbior. pod red. Wiesławy Hajduk. Białystok 2000 Libra ss. 298, nlb. 2, tabl. 1, il.

Toż. Wyd. 2. Białystok 2000 ss. 298 , nlb. 2, tabl. 1, il.

Zespót Szkó Handlowych i Ekonomicznych w Białymstoku.

293. WAJLER Anna: I Liceum Ogólnokształcace im. Boleslawa Chrobrego w Grudziądzu (1951-2001). Grudziądz 2001 I LO im. Bolesława Chrobrego ss. 148, nlb. 3, il.

294. WALISZEWSKI Stanisław: Gimnazjalne miraże. Wspomnienia. Państwowe Męskie Neoklasyczne Gimnazjum im. Przemysława II w Rogoźnie, Rogoźno i jego mieszkańcy w latach 1921 - 1929. Rogoźno 2001 Tow. Przyj. Rogoźna ss. 224, il. Biblioteka Rogozińskich Zeszytów Historycznych. Nr I.

295. ZIEMKIEWICZ Marek: Historia Zakładu Naukowo-Wychowawczego im. ks. Jana Długosza we Włocławku w latach 1916-1949. Włocławek 2001 Wydaw. Duszpasterstwa Rolników ss. 147, nlb. 1. Biblioteka Fundacji im. ks. Jana Długosza. Ser. A. Nr 2.

Gimnazjum i Liceum im. ks. Jana Dlugosza.

\section{Szkoły zawodowe}

296. BIENIAWSKA Jadwiga: Izba tradycji w Zespole Szkół Rolniczych w Miętnem. Muzeum Szkolne. Nr 45. Wkladka do czasop. Wiadom. Hist. R. 44: 2001 nr 2 s. 31 - 32.

$\mathrm{XX} w$.

297. HUSS Ryszard: Techniczna Szkoła Wojsk Lotniczych 1944-1995. Zamość 2001 Ryszard Huss ss. 466 , il.

298. KAPERA Joanna: Historia i współczesność Zespołu Szkół Mechanicznych w Nysie. Muzeum Szkolne. Nr 46. Wkładka do czasop. Wiadom. Hist. R. 44: 2001 nr 3 s. 35-37. Od $1946 \mathrm{r}$.

299. KARŁOWICZ Leon: Nie zawiedli. Lublin 2000 Polihymnia ss. 293.

Powojenna historia Technikum Pszczelarskiego w Pszczelej Woli. Zawiera także biogramy absolwentów.

300. KUBALA Joanna: Zespół Szkół Odzieżowych im. WI. St. Reymonta w Częstochowie. Muzeum Szkolne. Nr 46. Wkładka do czasop. Wiadom. Hist. R. 44: 2001 nr 3 s. $38-42$.

Od 1919 r.

301. MARSZAŁEK Jan: Szkoła Zawodowa w Chełmnie w latach 1861-2001. Chelmno 2001 Zespół Szkół Zawodowych ss. 139, il.

302. PRZESZŁOŚĆ, dziś, przyszłość 1960 - 2000. Zespół red. Małgorzata Śliwińska [i in.]. Nowa Dęba-Dębica 2000 ZSZ; Biuro Usług Komputerowych Stanisław Smaga ss. 72, il. Zespół Szkół Zawodowych im. Eugeniusza Kwiatkowskiego w Nowej Dębie.

Zespół Szkól Zawodowych im. Eugeniusza Kwiatkowskiego w Nowej Dębie.

303. SŁOWIK Urszula: Medyczne Studium Zawodowe Szkoła Techników Farmaceutycznych. Lata 1952 - 1987. W: Dzieje farmacji dolnoślaskiej 1945 - 2000. Oprac. zbior. pod red. Janusza Pluty, Joanny Piątkowskiej. Wrocław 2001 s. 196-203. 
304. STAWSKI Włodzimierz: Z dziejów Technikum Kinotechnicznego w Krakowie. Roczn. Komisji Nauk Pedagog. T. 54: 2001 s. 31-48.

305. ZESPÓŁ Szkół Przemysłu Spoźywczego w Kielcach 1951 - 2001. Księga pamiątkowa. Praca zbior. pod red. Zofii Dąbrowskiej, Małgorzaty Detki, Aldony Pawlik. Kielce 2001 Gens ss. 183, nlb. 1, tabl. 20.

306. ZIELIŃSKI Piotr: Gra w błękitne. Szczecin 2001 Germa ss. 173, nlb. 3, tabl. 30.

Dzieje Zespołu Szkół Ekonomicznych nr 2 im. Stanisława Staszica w Szczecinie, po 1945 r.

\section{Zakłady kształcenia nauczycieli (z wyjątkiem szkół wyższych)}

307. DOROSZEWSKI Jerzy: Podstawy prawne funkcjonowania seminariów nauczycielskich i ich rozwój organizacyjny w Polsce w latach 1918 - 1937. Przegl. Hist.-Ośw. R. 44: $2001 \mathrm{nr} 3 / 4$ s. 25 - 39.

308. GAJZLER Elżbieta: Das Staatliche Lehrerseminar mit deutscher Unterrichtssprache in Lodz. Jahrbuch Weichsel-Warthe. Bd. 46: 2000 s. 87-91.

Seminaria nauczycielskie w 1. 1866 - 1933.

309. JAŁMUŹNA Tadeusz: Zakłady kształcenia nauczycieli w Łodzi w latach 1918 - 1998. Łódź 2001 Wydaw. Uniw. Łódzkiego ss. 526, mapy.

310. MIERZEJEWSKI Czesław: Miejskie Seminarium Nauczycielskie w Łomży. Ziemia Łomżynska. [R.] 6: 2001 s. $189-200$.

Od 1917 r.

311. SNOCH Bogdan: Studium Nauczycielskie w Częstochowie (1957 - 1971) prekursor WSP. W: Przyzywanie głębi do kręgu słów, myśli, idei i działań. Księga jubileuszowa ofiarowana Profesorowi Józefowi Żurawowi. Pod red. Stanisława Podobińskiego i Bogdana Snocha. Częstochowa 1999 - 2000 - 2001 s. $755-760$.

312. WOJTYŃSKI Wacław: Kształcenie nauczycieli w dwudziestoleciu międzywojennym. Przegl. Hist.-Ośw. R. 44: $2001 \mathrm{nr} 1 / 2$ s. $51-63$.

313. WOLTMANN Bernard: Główne kierunki badań naukowych w Gorzowskim Ośrodku Kształcenia Nauczycieli Wychowania Fizycznego 1971 -1999. Prace Nauk. [WSP w Częstochowie]. Kultura Fizyczna. Z. 4: 2001 s. $101-112$, sum.

Charakterystyka działalności i bibliografia prac m.in. z historii sportu.

\section{Szkoły wyższe}

\section{Akademia Ekonomiczna w Krakowie}

314. BROŃSKI Krzysztof, Filar Tadeusz: Szkoła Przedsiębiorczości i Zarzadzania Akademii Ekonomicznej w Krakowie w latach 1991 - 2001. Przy wspólpr. Elżbiety Burkot [i in.]; red. nauk. Jan Szpak. Kraków 2001 SPiZ AE ss. 182, il. Szkoła Przedsiębiorczości i Zarządzania Akad. Ekonomicznej w Krakowie.

\section{Akademia Lekarska w Gdańsku}

315. MACHALIŃSKI Zbigniew: Rola Wydziału Lekarskiego Uniwersytetu Stefana Batorego w Wilnie w powstaniu Akademii Lekarskiej w Gdańsku. Kwart. Hist. Nauki i Techn. R. 46: $2001 \mathrm{nr} 1$ s. $101-112$, sum.

Lata $1945-1950$. 


\section{Akademia Medyczna w Poznaniu}

316. MY o sobie. Pamiętnik zjazdu z okazji 50-lecia uzyskania dyplomów lekarskich Akademii Medycznej im. Karola Marcinkowskiego - w roku 1951. Pod red. Jana Hasika. Poznań 2001 AM ss. 179, nlb. 3, il. Akad. Medyczna im. Karola Marcinkowskiego w Poznaniu.

Z treści: Bartkowiak Zbigniew: O losach absolwentów i naszych Alma Mater s. 6-26; Wykaz absolwentów z rocznika 1951 Wydziału Lekarskiego Akademii Medycznej im. K. Marcinkowskiego w Poznaniu s. 30 - 37; Wykaz zmariych profesorów s. 38; Wykaz zmarlych absolwentów s. 39 - 42; Lista absolwentów, o których brak jakichkolwiek danych... s. 43; Biogramy (w alfabetycznej kolejności) s. 44-179.

\section{Akademia Medyczna w Lodzi}

317. ŚWIETLICZKO Irena: Katedra i Klinika Chorób Oczu Akademii Medycznej w Łodzi (lata 1945 - 1993). W: Historia łódzkiej okulistyki. Oprac. zbior. pod red. Janusza Czajkowskiego. Warszawa 2000 Oftal s. $9-44$.

\section{Akademia Medyczna we Wrocławiu}

318. PALCZEWSKA Wiktoria: Studenci o swoim Wydziale Farmaceutycznym AM we Wroctawiu. W: Dzieje farmacji dolnoślaskiej 1945-2000. Oprac. zbior. pod red. Janusza Pluty, Joanny Piątkowskiej. Wrocław 2001 s. $28-29$.

\section{Akademia Muzyczna we Wrocławiu}

319. EDUKACYJNA i artystyczna rola Wydziału Wychowania Muzycznego w 50-letniej działalności Akademii Muzycznej we Wrocławiu. Materiały z ogólnopolskiej sesji naukowej, 27-28 listopada 1998. Red. Barbara Strzyżewska-Marciniak. Wrocław 2001 AM ss. 168, tabl. 10, il. Akad. Muzyczna im. Karola Lipińskiego we Wrocławiu. Wydz. Edukacji Muzycznej. Zeszyt Naukowy. Nr 79.

\section{Akademia Podlaska w Siedlcach}

320. [DZIESIEĆ] $X$ lat Wydziału Humanistycznego Akademii Podlaskiej w Siedlcach (1991 - 2001). Praca zbiorowa. Pod red. Jarosława Cabaja i Piotra Matusaka. Siedlce 2001 Wydaw. AP ss. 163, il. Akad. Podlaska.

Z treści: Cabaj Jarosław: Zarys historii Wydziału (1969 - 1991) s. 9-26; Matusak Piotr: Wydzial Humanistyczny Akademii Podlaskiej w Siedlcach 1991-2001 s. 27-48; Rosa Ryszard: Instytut Pedagogiki s. 49-78; Gryciuk Franciszek: Instytut Filologii Polskiej s. 79-89; Ważniewski Władysław: Instytut Historii s. 89-102; Jaroń Józef: Katedra Filozofii i Socjologii s. 103-112; Dyrda Mirosław: Katedra Psychologii s. 113-118; Wojtczuk Krystyna: Dorobek naukowy i wydawniczy s. 119 - 135; Maliszewski Adam: Samorzad Studencki s. 137 - 139; Aneksy: Sylwetki dziekanów i prodziekanów s. $140-148$.

\section{Akademia Rolnicza we Wrocławiu}

321. DZIEJE Akademii Rolniczej we Wroclawiu. Pod red. Jerzego Soboty, Tadeusza Szulca i Jakuba Tyszkiewicza. Wrocław 2001 Wydaw. Akad. Rolniczej 4 ss. 520, nlb. 1, il.

Z treści: Radomska Maria: Dublany s. 9 - 19; Wyrost Piotr: Lwów s. 19 -34; Śniady Roman Andrzej: Breslau s. 34-41; Tyszkiewicz Jakub: Wrocław s. 41-45; Nasze 50 lat, $1951-2001$ s. 47-72; [Poszczególne wydziały, jednostki pozawydziałowe, organizacje i kadra naukowa] s. 73-520.

\section{Akademia Techniczno-Rolnicza w Bydgoszczy}

322. KATAFIAS Jolanta, Pawlak Marian: Włocławski Oddział Instytutu Rolniczego Akademii Techniczno-Rolniczej im. Jana i Jędrzeja Śniadeckich w Bydgoszczy $(1979-1984)$. Włocławek 2001 Wyższa Szkoła Humanist.-Ekonom. we Włocławku ss. 98, nlb. 2.

323. [PIĘĆDZIESIAT] 50 lat Akademii Techniczno-Rolniczej im. Jana i Jędrzeja Śniadeckich w Bydgoszczy. Red. wyd. Andrzej Jazon, Maciej M. Kozłowski; oprac. red. Elżbieta Rudzińska. Bydgoszcz 2001 Wydaw. Uczelniane Akad. Techn.-Rolniczej 4 ss. 284, tabl. 42, il. 


\section{Akademia Teologii Katolickiej}

324. WYDZIAŁ Filozofii Chrześcijańskiej na Akademii Teologii Katolickiej 1954 - 1999. Red. Jan Bielecki i Jan Krokos. Warszawa 2001 Wydaw. Uniw. Kard. S. Wyszyńskiego ss. 337, nlb. 2.

\section{Akademia Wychowania Fizycznego w Warszawie}

325. KRAWCZYK Zbigniew: Katedra Nauk Społecznych AWF w Warszawie, działalność naukowo-dydaktyczna. Roczniki Nauk. AWF w Warszawie. T. 40: 2001 s. 41 -56, sum.

Po $1946 \mathrm{r}$.

\section{Akademia Zamojska}

326. GMITEREK Henryk: Akademia Zamojska w okresie panowania Augusta II. W: Rzeczpospolita w dobie wielkiej wojny północnej. Pod red. Jadwigi Muszyńskiej. Kielce 2001 s. 307-315.

327. GMITEREK H.: Ze studiów nad struktura wyznaniową młodzieży Akademii Zamojskiej (1595-1784). Res Historica. Z. 10: 2000 s. $221-231$.

328. KAROLEWICZ Grażyna: Mistrzowie we wspomnieniach swoich uczniów. Kartka z dziejów Katolickiego Uniwersytetu Lubelskiego. Lublin 2001 Red. Wydawnictw KUL ss. 61, nlb. 2, il. Katolicki Uniw. Lubelski.

Swiat profesorów KUL opisany na podstawie relacji studentów tej uczelni z l. 1918-1939.

\section{Państwowe Konserwatorium Muzyczne w Katowicach}

329. DYRDA Jerzy Marian: Wojskowa Szkoła Muzyczna przy Państwowym Konserwatorium Muzycznym w Katowicach w latach 1930 -1939. Studia Ślaskie. T. 60: 2001 s. 181-196.

\section{Politechnika Częstochowska}

330. GASIORSKI Aleksander: Od Katedry Elektrotechniki do Wydziału Elektrycznego Politechniki Częstochowskiej. Szkic monograficzny w 50-lecie Katedry Elektrotechniki (1951 - 2001) i 35-lecie Wydziału Elektrycznego Politechniki Częstochowskiej (1966-2001). Częstochowa 2001 Wydaw. Politech. Częstochowskiej ss. 137, il., rez., sum.

\section{Politechnika Rzeszowska}

331. OCZOŚ Kazimierz E.: Politechnika Rzeszowska im. Ignacego Łukasiewicza 1951 - 2001. Od Wieczorowej Szkoły Inżynierskiej w Rzeszowie do Politechniki Rzeszowskiej. Rzeszów 2001 Oficyna Wydawnicza Politech. Rzeszowskiej ss. 478, il, mapa.

\section{Politechnika Śląska}

332. [TRZYDZIESTOLECIE] XXX-lecie Instytutu Techniki Cieplnej Politechniki Ślaskiej. Lwowskie tradycje. Śląska szkoła termodynamiki i energetyki cieplnej. Zebrali i oprac. Andrzej Ziębik, Józef Szymczyk. Gliwice 2001 Politech. Śląska ss. 119, il.

W Gliwicach.

\section{Seminarium Duchowne w Krakowie}

333. SEMINARIUM duchowne w Krakowie. 400-lecie. Red. Józef Guzdek, Franciszek Ślusarczyk. Kraków 2001 Wydaw. Św. Stanisława BM Archidiec. Krakowskiej ss. 349, nlb. 3, il.

Z treści: Czerwień Jerzy: Zarys dziejów seminarium duchownego w Krakowie s. 19-49; Sochacki Zdzisław, Ślusarczyk F.: Z dzjejów seminaryjnych budynków s. 50-67; Slusarczyk F.: Alumni-żołnierze w Ludowym Wojsku Polskim s. 71-76; Cmiel Edward: Troska o życie duchowe s. 77-89; Żelazny Jan: Współpraca seminarium z Wydziałem Teologicznym s. 90-94; Nowak Jan; Posługa sióstr Miłosierdzia św. Wincentego à Paulo s. 95 - 101; Ślusarczyk F.: Pasterz ponad podziałami - bł. Abp Józef Bilczewski s. 114-118; Slaweński Roman: Świadek Wielkiego Piątku - bł. ks. Piotr Dańkowski s. 119-128; Aneks: Absolwenci seminarium (1901 - 2001) s. 312 - 326; Żelazny J., Mateja Leszek: Zmarli przełożeni seminarium duchownego w Krakowie s. 337-348. 


\section{Szkoła Akademiczno-Górnicza w Kielcach}

334. ADAMCZYK Stanisław J.: Szkoła Akademiczno-Górnicza w Kielcach. W: Region świętokrzyski. Mit czy rzeczywistość? Materiały konferencji naukowej Kielce, 23 maja 2001. Pod red. Jacka Wijaczki. Kielce 2001 s. $191-208$.

\section{Szkoła Podchorążych Sanitarnych}

335. MORAWSKI Tomasz: Była taka podchorażówka w Warszawie... (Wychowankowie Szkoły Podchorażych Sanitarnych 1922 - 2001). Medycyna Nowożytna. T. 8: 2001 z. 2 s. $217-222$, sum., Zsfg. Wystawa 28 VI - 30 XII 2001 r. w Glównej Bibliotece Lekarskiej w Warszawie.

\section{Szkoła Specjalistów Morskich Wojsk Ochrony Pogranicza}

336. BIENIECKI Ireneusz: Szkoła Specjalistów Morskich Wojsk Ochrony Pogranicza (1950-1967). Biul. Hist. [Muzeum Marynarki Wojennej]. Nr 17: 2001 s. $95-102$.

\section{Uniwersytet Adama Mickiewicza w Poznaniu}

337. KSIĘGA pamiatkowa w 80-lecie Uniwersyteckiego Wydziału Lekarskiego w Poznaniu. Studia i materiały. Pod red. Romana K. Meissnera. Poznań 2001 Dział Wydawnictw Uczelnianych AM ss. 534, nlb. 2, il., sum. Biblioteka Prac Historycznych Akademii Medycznej im. Karola Marcinkowskiego w Poznaniu. Ser. A. T. 4.

Z treści: Meissner R. K.: Uniwersytecki Wydział Lekarski w Poznaniu z perspektywy roku 2000 s. 7 - 31; Jurga Stefan: Wydzial Lekarski Uniwersytetu Poznańskiego s. 32 - 37; Obrębowski Andrzej: Refleksje z okazji 80-lecia Wydziału Lekarskiego Akademii Medycznej im. Karola Marcinkowskiego s. 40 - 46; Meissner R. K.: Patron Akademii Medycznej w Poznaniu - dr Karol Marcinkowski [1800 - 1846] s. 51 - 59; Tenże: Twórca Uniwersytetu Poznańskiego prof. dr h.c. UJ i UP - Heliodor Święcicki [1854-1923] s. 60-70; Tenże: Organizator i pierwszy dziekan Wydziału Lekarskiego Uniwersytetu Poznańskiego prof. dr hab. dr h.c. USB, UJ i AM w Poznaniu Adam Wrzosek (1875-1965) s. 71-83; Rektorzy Akademii Medycznej w Poznaniu s. 85-154; Dziekani Wydziału Lekarskiego Uniwersytetu Poznańskiego i Akademii Medycznej s. 155 - 304; Piotrowicz Aniela: Studenci Wydziału Lekarskiego UP i Akademii Medycznej w liczbach s. 305-307; Meissner R. K.: Wydział Lekarski Tajnego Uniwersytetu Ziem Zachodnich (1942 - 1945) i nie publikowane wspomnienia jego studentów s. 308 - 339: Tenże: Polski Wydział Lekarski w świetle "nowych" dokumentów archiwalnych s. 340 - 363; Meissner R. K.: Medal im. Karola Marcinkowskiego i jego laureaci s. 384-391; Wrzosek Adam: Pierwsze lata Wydziału Lekarskiego Uniwersyteru Poznańskiego s. 395-408; Kapuściński Witold sen.: Pierwsi profesorowie Wydziału Lekarskiego Uniwersyteru Poznańskiego s. 409-411; Tomaszewski Wiktor: Garść wspomnień z polskiego Wydziału Lekarskiego w Edynburgu s. 412 - 419; Flieger Stefan: Przed półwieczem - jak dzisiaj s. 420 - 427; Gabryel Przemysław: Moja „Alma Mater" - moje studia i praca dla niej s. 428-438; Szmeja Zygmunt: Dawnych wspomnień czar s. 439-452; Kulczyński Bronisław: Stowarzyszenie Absolwentów Akademii Medycznej im. Karola Marcinkowskiego - historia i teraźniejszość s. 453-457.

\section{Uniwersytet Jagielloński}

338. BARCIK Mieczysław: Wydział Teologiczny Uniwersytetu Jagiellońskiego (1939-1954). Kraków 2001 Wydaw. Nauk. PAT ss. 182, tabl. 32, il. Papieska Akad. Teol. w Krakowie. Studia do Dziejów Wydziału Teologicznego Uniwersytetu Jagiellońskiego. T. 13/1.

339. BARCIK M., Cieślak Adam: Z Uniwersytetu Jagiellońskiego do mogił katyńskich. Wystawa w Archiwum UJ. Alma Mater. Nr 31: 2001 s. 33-34.

6-8 VI $2001 \mathrm{r}$.

340. CICHOCKI Andrzej: Działalność i osiagnięcia Katedry i Zakładu Technologii Chemicznej Uniwersytetu Jagiellońskiego w Krakowie w latach 1951-1997 oraz zwiazanych z nim zespołów badawczych: Zespołu Sit Molekularnych i Adsorbentów (1970-1999), Zespołu Syntezy Zeolitów (1970-1987). Analecta. R. 10: 2001 z. 1 s. $163-216$, sum.

341. CIEŚLAK Adam: Okupacyjny epizod Zakładu Bakteriologii UJ. Alma Mater. Nr 28: 2001 s. $22-25$.

342. DOBOSZ Piotr: Dobroczynne winietki akademickie. Alma Mater. Nr 27: 2000/2001 [druk.:] 2001 s. $41-43$. 
343. GAJDA Zdzisław: The Museum of the Faculty of Medicine at the Jagiellonian University. Transl. by Teresa Bułak-Ulewiczowa. Cracow 2000 Katedra Historii Medycyny CM - Collegium Medicum Uniw. Jagiell. ss. 122, il.

Tytuł oryg.: Muzeum Wydziału Lekarskiego Uniwersytetu Jagiellońskiego. Kraków 1998.

344. GASIOROWSKI Antoni: [Mikołaj] Bylina i inni. Dziekani Wydziału Sztuk krakowskiego uniwersytetu w XV wieku. W: Ludzie - Kościół - wierzenia. Studia z dziejów kultury i społeczeństwa Europy Środkowej (średniowiecze - wczesna epoka nowożytna). Red. Wojciech Iwańczak, Stefan K[rzysztof] Kuczyński. Warszawa 2001 s. 523-537.

345. GRODZISKI Stanisław: Sto lat Wydziału Prawa Uniwersytetu Jagiellońskiego we wspomnieniach. Studia Hist. R. 44: 2001 z. 2 s. 289-300, sum.

Na temat wspomnień Fryderyka Zolla (Wspomnienia... Kraków 2000) i Stefana Grzybowskiego (Wspomnienia. Kraków 1999).

346. KOLKA Wojciech Piotr: Klinika Położniczo-Ginekologiczna Uniwersytetu Jagiellońskiego w Krakowie w latach 1918 - 1939. Kraków [2000] CM UJ ss. 247, nlb. 1, tabl. 24. Uniw. Jagielloński. Collegium Medicum - Wydz. Lekarski.

347. KOLKA W. P.: Klinika Położniczo-Ginekologiczna Uniwersytetu Jagiellońskiego w latach 1918 - 1939. Kraków 2001 Zakł. Historii Medycyny UJ ss. 163, nlb. 1, il., sum. Rozprawy z Historii Medycyny i Filozofii Medycyny. [T.] 10.

348. KOMOROWSKI Ryszard: Medale jubileuszowe UJ. Alma Mater. Nr 33: 2001 s. $18-20$.

Lata $1900-1997$.

349. LINK-LENCZOWSKI Andrzej K[rzysztof]: Droga do nowoczesnej judaistyki. Od Międzywydziałowego Zakładu Historii i Kultury Żydów w Polsce do Katedry Judaistyki. Alma Mater. Nr 29: 2001 s. $26-27$.

350. MYCIELSKI Przemysław: Studenci z Cieszyna na Uniwersytecie Krakowskim w Średniowieczu i dobie wczesnonowożytnej (1400-1561). Pamiętn. Cieszyński. T. 16: 2001 s. 5-12.

351. PERKOWSKA Urszula: Jubileusz roku 1964. Z dziejów uroczystości jubileuszowych 600-lecia utworzenia Uniwersytetu Jagiellońskiego. Alma Mater. Nr 27: 2000/2001 [druk.:] 2001 s. 25-27.

352. PILARCZYK Krzysztof: Studia żydowskie na Uniwersytecie Jagiellońskim w Krakowie (1986-2000). Od historii i kultury Żydów w Polsce do judaistyki. Studia Judaica. R. 3: 2000 nr 2 [druk.:] 2001 s. $211-227$.

353. SKOTNICKI Aleksander B.: Uniwersytet Jagielloński na pocztówkach krakowskich z przelomu wieków. Alma Mater. Nr 35: 2001 s. $31-35$.

$\mathrm{XIX} / \mathrm{XX}$ w.

354. SKRZYPEK Marian: Kołlatajowska reforma Wydziału Filozoficznego Uniwersytetu Krakowskiego. Archiwum Hist. Filoz. i Myśli Spot. [T.] 46: 2001 s. 27-46.

W aneksie: Kołłataj Hugo: Porzadek studiów dla Wydziału Filozoficznego Uniwersytetu Krakowskiego [Kraków, 1 X 1778 r.] s. 47-58.

355. SOŁTAN Aleksandra J.: Studenci z Mazowsza Płockiego na Akademii Krakowskiej w drugiej połowie XVI wieku. Warszawa i Mazowsze. T. 5: 2001 s. 21 - 46.

356. SRZEDNICKI Czesław, Tomaszkiewicz Wiesław: Warto wspomnieć tamte lata. Pierwsze powojenne lata studiów na orientalistyce. Alma Mater. Nr 28: 2001 s. 29-31.

357. STOPKA Krzysztof, Banach Andrzej Kazimierz, Dybiec Julian: Dzieje Uniwersytetu Jagiellońskiego. Kraków 2000 Wydaw. Uniw. Jagiell. ss. 242, il.

Toż. w jęz. ang.: The History of Jagiellonian University. Kraków 2000 ss. 256, il. 
358. SZKARADNIK Przemysław: Mistrzowie Uniwersytetu Krakowskiego z Oświęcimia w XV i na poczatku XVI wieku. Krakowski Roczn. Archiw. [T.] 7: 2001 s. 61-80, sum.

359. WOJCIECHOWSKI Daniel: „Dynastia” Kurzelowitów w dziejach Uniwersytetu Jagiellońskiego w Krakowie. Kurzelów-Kielce 2001 Jedność ss. 237, nlb. 2, il.

XVI-XVII w.

360. ZIEBA Andrzej [Aleksander]: Szkoła Nauk Politycznych Uniwersytetu Jagiellońskiego. Czasop. Prawno-Hist. T. 53: 2001 z. 2 s. $211-224$.

Lata 1920 - 1949.

\section{Uniwersytet Mikołaja Kopernika}

361. KALEMBKA Sławomir: Zofia Mołodcówna i Witold Armon - twórcy podstaw Katedry Bibliotekoznawstwa UMK. Acta Univ. N. Copernici. Nauki Humanist.-Spol. Z. 340: Bibliologia. [Nr] 4: 2000 s. $11-24$.

362. STASZEWSKI Jacek: 55 lat Uniwersytetu Mikolaja Kopernika. Roczn. Toruński. [T.] 28: 2001 s. 25-35.

\section{Uniwersytet Stefana Batorego}

363. DALECKA Teresa: Polityczne konflikty i spory na Uniwersytecie Stefana Batorego w Wilnic w latach 1919-1939. Zagadn. Naukozn. T. 37: 2001 z. 3/4 s. 467-480.

364. JUČAS Mečislovas: Motywacje polityezne powołania Uniwersytetu Wileńskiego. Ku czci jubileuszu 420-lecia Uniwersytetu. W: Jezuicka ars historica. Prace ofiarowane Księdzu Profesorowi Ludwikowi Grzebieniowi SJ. Red. Marek Inglot, Stanisław Obirek. Kraków 2001 s. 209-218.

365. PIECHOWIAK-TOPOLSKA Maria B.: „Wilno w Londynie”. Dzieje Uniwersytetu Stefana Batorego na emigracji po II wojnie światowej. W: Nauka polska na obczyźnie. Stan i perspektywy badawcze. Konferencja naukowa 11 - 12 września 1998 r. w Zielone Górze. Red. Wiesław Hładkiewicz, Marek Szczerbiński. Gorzów Wlkp. 2000 RPBnP s. 48 - 56. Prace Naukowe Rady Porozumiewawczej Badań nad Polonia. Materiały z Konferencji. T. 3.

366. SZTACHELSKA Irena: Kilka wspomnień o niektórych moich profesorach z Wydziału Lekarskiego Uniwersytetu Stefana Batorego z lat 1929-1939. Archiwum Hist. i Filoz Med. T. 64: 2001 z. $2 / 3$ s. $213-226$.

\section{Uniwersytet Szczeciński}

367. KOŹMIAN Danuta: Droga do Uniwersytetu Szczecińskiego w opinii prasy centralnej i regionalnej w latach 1981 - 1985. (W 15. rocznicę powstania uczelni). Szczecin 2000 Wydaw. Nauk. US ss. 180, sum. Rozprawy i Studia. Uniw. Szczeciński. T. 350.

Rec.: Kość Ilona, Przegl. Zuchodniopomorski. T. 16: 2001 z. 3 s. 276-279.

368. LASKIEWICZ Henryk: Instytut Kultury Fizycznej w Szczecinie (1950 - 2000). Szczecin 2001 Wydaw. Nauk. US ss. 261, il. Uniw. Szczeciński. Wydz. Nauk Przyrodniczych. Inst. Kultury Fizycznej.

\section{Uniwersytet w Edynburgu - Polski Wydział Lekarski}

369. NOWAK Kazimierz: Znaczenie Polskiego Wydziału Lekarskiego w Edynburgu (1940 - 1949). W: Nauka polska na obczyźnie. Stan i perspektywy badawcze. Konferencja naukowa 11 - 12 września 1998 r. w Zielone Górze. Red. Wiesław Hładkiewicz, Marek Szczerbiński. Gorzów Wlkp. 2000 s. $127-135$.

\section{Uniwersytet Warszawski}

370. BOHUN Tomasz: Ewakuacja Cesarskiego Uniwersytetu Warszawskiego do Rostowa nad Donem w 1915 roku. Przegl. Hist. T. 92: 2001 z. 3 s. 323-337, sum. s. 390. 
371. GAUDEAMUS. 80 lat Chóru Akademickiego Uniwersytetu Warszawskiego. Red. Maria Wojciechowska. Warszawa 2001 Wydaw. Uniw. Warszawskiego ss. 285, nlb. 13, il.

Z treści: Jędrych-Pordes Elżbieta: Lata dwudzieste - lata pię́ćdziesiąte (1921-1939 i 1954-1963) s. 7-44; Rzeszotarska Jadwiga: Pod batuta Mirosława Perza: być razem w najlepszym stylu (1963 - 1968) s. 45 - 66; Laskowska Maria: Sukcesy zespołu z Maciejem Jaśkiewiczem (1968-1972) s. 67-110; Tumiłowicz Bronisław, Grabiszewska-Gryka Marzenna: Za „Drugiego Perza” (1972-1978) s. 111 -162; Ciż: Bananowe spiewanie (1978-1980) s. 163-184; Dominiczak Robert, Felczyńska-Paczkowska Maria, Paczkowski Szymon: Cienie i blaski lat osiemdziesiatych (1981-1989) s. 185-220; Janik Maria, Leśkiewicz Anna: Ostatnie dziesięciolecie (1989-2001) s. $221-260$.

\section{Uniwersytet Wrocławski}

372. BŁASZCZYK Tomasz: Fakultet teologii katolickiej Uniwersytetu Wrocławskiego w latach 1811 - 1914. Aspekt historyczno-prawny. Legnica 2001 Na zlec. Wyższego Seminarium Duchownego Diẹc. Legnickiej; Alta 2 ss. 298. Biblioteka Diecezji Legnickiej. [T.] 2.

373. BŁASZCZYK T.: Wydział Teologii Katolickiej Uniwersytetu Wrocławskiego a sprawa [Jana] Antoniego Theinera jako przywódcy śląskich neologów. Studia Teol.-Hist. Ślaska Opolskiego. T. 21: 2001 s. $269-279$, Zsfg.

XIX w.

374. MALICKA Sylwia: Studium Wojskowe Uniwersytetu Wrocławskiego w latach 1950 - 1970. W: [Pięćdziesięciopięciolecie] 55-lecie zakończenia II wojny światowej i powstania Ślaskiego Okręgu Wojskowego. Materiały z konferencji naukowej. Pod red. Franciszka Kusiaka. Wrocław 2000 s. $92-97$.

375. WIKTOR-SZTROMWASSER Zofia: Muzeum Antropologiczne w Collegium Anthropologicum Uniwersytetu Wrocławskiego. Dolny Ślask. Nr 9: 2001 s. 74-77.

Od $1945 \mathrm{r}$.

\section{Wyższa Szkoła Pedagogiczna w Częstochowie}

376. LESZ-DUK Maria: Zarys historii polonistyki częstochowskiej. W: W kręgu literatury, języka i kultury. Tom jubileuszowy z okazji trzydziestolecia Wyższej Szkoły Pedagogicznej w Częstochowie. Pod red. Anety Majkowskiej i Marii Lesz-Duk. Częstochowa 2001 s. 9-11.

\section{Wyższa Szkoła Pedagogiczna w Rzeszowie}

377. DZIEJE Wyższej Szkoły Pedagogicznej w Rzeszowie 1965-2000. Pod red. Włodzimierza Bonusiaka. Rzeszów 2001 Wydaw. Wyższej Szkoły Pedagog. ss. 510, nlb. 2, tabl., il.

\section{Wyższe Seminarium Duchowne w Częstochowie}

378. KOWALSKI Jan: Źrenica oka diecezji. Siedemdziesięciopięciolecie Wyższego Seminarium Duchownego Kościoła Częstochowskiego (1926-2001). Częstochowa 2001 Regina Poloniae ss. 92, nlb. 3, rès., Zsfg.

379. ZWIAZZEK Jan: Wyższe Seminarium Duchowne Diecezji Częstochowskiej w Krakowie i Częstochowie (1926-2001). Czestochowskie Studia Teol. [T.] 29: 2001 s. 293 - 308.

\section{Wyższe Seminarium Duchowne w Lodzi}

380. ZWOLIŃSKI Piotr: Wyższe Seminarium Duchowne w Łodzi 1921-2000. Łódź 2001 Archidiec. Wydaw. Łódzkie ss. 151, il.

\section{Wyższe Seminarium Duchowne we Wrocławiu}

381. RULKA Kazimierz: Księgozbiór księży Chodyńskich w Bibliotece Wyższego Seminarium Duchownego we Wrocławiu. Studia Wtoctawskie. T. 3: 2000 s. 418-438.

Księgozbiór braci Zenona (1836-1887) i Stanisława (1836-1919) Chodyńskich, profesorów i rektorów seminarium wrocławskiego. 


\section{BIOGRAFIE}

\section{Zbiory życiorysów}

382. BYLI wśród nas. Wspomnienia i biogramy. Pod red. Zenobii Knakiewicz. [Wyd. 2]. Poznań 2001 Wydaw. AE ss. 313, nlb. 1, il. Akad. Ekonom. w Poznaniu.

Z treści: Knakiewicz Z: Wprowadzenie s. 17-25; Toż w jęz. ang. s. 26-34; Wspomnienia [biogramy]. Wspołzalożyciele Wyższej Szkoły Handlowej s. 37-51; Wykładowcy przedmiotów nauk prawno-ekonomicznych i socjologicznych s. 55-237; Wykładowcy przedmiotów nauk towaroznawczych s. 243-279; Pozostali pracownicy
s. $283-314$.

Wyd. 1. 1997.

383. DAZBROWSKI Stanisław Jan, Tryczyński Stanisław Arkadiusz: Słownik biograficzny lubelskiego harcerstwa 1911 -2001. Wyd. 2. Lublin 2001 Komenda Choragwi Zw. Harcerstwa Pol. ss. 209 , nlb. 6 .

384. EKSPERCI oświaty. Słownik biograficzny. Red. Denis I. Dembek. Eysomice 2001 Temat ss. 168 , nlb. 2 , il.

$\mathrm{XX}$ w.

385. MATERIAŁY V Sympozjum Biografistyki Polonijnej. Kraków, 22 - 23 września 2000. Pod red. Agaty Judyckiej i Bolesława Klimaszewskiego. Lublin 2000 Czelej ss. 520.

$Z$ treści: Nowak Janusz: Feliks Wrotnowski i jego „Elementarz dla dzieci polskich” 1839- 1851 s. 132 - 144; Wiech Stanisław: Działalność naukowo-pedagogiczna Aleksandra Mickiewicza na Uniwersytecie Kijowskim i Charkowskim s. 184-192; Malczewski Zdzisław: Sylwetka polskiego pedagoga w Brazylii na przykładzie Hieronima Durskiego i Henryka Siewierskiego s. 222-225; Szarifżanow Izmai 1.: Polacy-wykładowcy uniwersytetu kazańskiego oraz innych uczelni w Kazaniu s. 241 - 251; Caban Wiesław: Działalność oświatowo-naukowa polskich zeslańców na linii orenburskiej w pierwszej poł. XIX w. s. 252-258; Olszewski Edward: Uczeni i pedagodzy polscy w Norwegii s. 280-287; Gałkowski Adam: Uczeni i pedagodzy polscy we Francji u progu XXI wieku s. 288-300; Krzysztoforska-Weisswasser Zofia: Działalność polskich nauczycielek w Austrii s. $301-310$.

Rec.: Pilch Andrzej, Studia Hist. R. 44: 2001 z. 2 s. $354-356$.

386. MISTRZOWIE i nauczyciele: profesorowie Seminarium Duchownego w Plocku 1965 - 2000. Red. Ireneusz Mroczkowski. Lublin 2001 Płocki ss. 555, nlb. 3, il.

387. MIZERKA Barbara: Polsce zawsze wierni. Profesorowie Państwowego Gimnazjum i Liceum im. św. Stanisława Kostki w Kościanie - Władysław Kyc, Kazimierz Ossecki, Stanisław Schoen, Józef Skalecki. Kościan 2001 SAGiL ss. 48, il. Stow. Absolwentów Gimnazjum i Liceum w Kościanie. Nasi Profesorowie.

$\mathrm{XX}$ w.

388. NARKOWICZ Liliana: Znani i nieznani profesorowie medycyny Uniwersytetu Wileńskiego I poł. XIX w. Profesorowie wydziału lekarskiego Uniwersytetu Wileńskiego pierwszego ćwierćwiecza XIX wieku oraz Akademii Medyko-Chirurgicznej w Wilnie. Bydgoszcz 2001 Tow. Miłośn. Wilna i Ziemi Wileńskiej. Oddz. ss. 116, il. Biblioteka Wileńskich Rozmaitości. Ser. A. Nr 19.

389. PIATKOWSKI Sebastian: Przyczynki do biografii nauczycieli Szkoły Powszechnej w Janowcu w latach 1918-1945. Notatnik Janowiecki. Nr 11: 2000 s. $71-79$.

390. PIŁATOWICZ Józef: Poczet rektorów. Tradycja i współczesność Politechniki Warszawskiej 1826 - 2001. Warszawa 2001 Oficyna Wydaw. Politech. Warszawskiej ss. 283, il.

391. STO lat polskiej katechezy. Wkład wybitnych polskich katechetów w odnowę i rozwój polskiej katechezy. Praca zbiorowa. Pod red. Ryszarda Czekalskiego. Kraków 2001 Wydaw. WAM ss. 177. Studia Pedagogiczne.

Sympozjum Sekcji Wykładowców Katechetyki Wyższych Seminariów Duchownych w Polsce. Czestochowa, 26-27 września $2000 \mathrm{r}$. 
Treść: Kubik Władysław: Ksiądz Walenty Gadowski (1861-1956). Ksiądz Zygmunt Bielawski (1877-1939) s. 11-35; Rozen Barbara: Ksiądz Józef Wojtukiewicz (1901-1989) s. 36-67; Szpet Jan: Ksiądz Marian Finke (1906-1986) s. 68-98; Marczewski Marek: Od duszpasterstwa ku ewangelizacji. Sługa Boży ksiadz Franciszek Blachnicki (1921 - 1987) s. 99-140; Kulpaczyński Stanisław: Ksiądz Profesor Mieczysław Majewski (1928 - 1999) s. 141 - 158; Offmański Andrzej: $Z$ pokolenia nieustannie poszukujacych. Wkład Jana Charytańskiego SJ w odnowe i rozwój polskiej katechezy s. $159-177$.

392. [TRZYSTA pięćdziesiąt] 350 lat Wyższego Seminarium Duchownego w Pelplinie (1651 - 2001). Księga jubileuszowa. Red. Anastazy Nadolny. Pelplin 2001 Bernardinum ss. 846, tabl. 34 , il.

Biografie profesorów i absolwentów.

393. VILLARDCZYCY. Słownik biograficzny. Red. Ewa Staczek. Wrocław 2000 E. Stączek ss. 198 , nlb. 2 , il.

Gimnazjum i Liceum im. Cypriana Norwida w Villard-de-Lans we Francji w l. 1939-1945.

\section{Poszczególne osoby}

\section{Ambroziewicz Wiktor}

394. NOWACKI Tadeusz Wacław: Z Polską w sercu. Rzecz o Wiktorze Ambroziewiczu [1882 - 1968]. Warszawa 2001 Wydaw. Wyższej Szkoły Pedagog. TWP [Tow. Wiedzy Powszechnej] ss. 383 , nlb. 3, tabl. 22, il. Wielcy Wychowawcy.

\section{Balcerak Wieslaw}

395. CHMIELIŃSKI Bolesław: Profesor dr hab. Wiesław Balcerak - założyciel i rektor Mazowieckiej Wyższej Szkoły Humanistyczno-Pedagogicznej w Łowiczu. Studia z Dziejów Rosji i Europy Srodk.-Wsch. T. 36: 2001 s. 11-17.

\section{Baranowski Mieczysław}

396. ĆWIK Wioletta: Mieczysław Baranowski [1851 - 1898] - reformator polskiego szkolnictwa galicyjskiego. Przegl. Hist.-Ośw. R. 44: $2001 \mathrm{nr}$ 3/4 s. $109-115$.

\section{Dobrzański Jan}

397. JAN Dobrzański [1901 - 1997] - profesor, mistrz i przyjaciel. Red. Kazimierz Przybyłko. Lublin 2001 Red. Wydaw. KUL ss. 222, il.

Treśc: Przybyłko K.: Rys biograficzno-historyczny Jana Dobrzańskiego s. 8-17; Rozdz. I: Działalność pedagogiczna i wychowawcza w Państwowym Gimnazjum i Liceum im. Stanisława Staszica w latach 1926-1939 i 1944 - 1952 i Liceum dla Dorosłych im. Tadeusza Kościuszki 1944-1947 w Lublinie s. 21 -29; Rozdz. II: Praca naukowo-dydaktyczna w Katolickim Uniwersytecie Lubelskim (1945-1956) s. 33-99; Rozdz. III: Działalność naukowo-dydaktyczna w Uniwersytecie Marii Curie-Skłodowskiej w latach 1956-1971 s. 103-137; Rozdz. IV: Wspomnienia i refleksje retrospektywne s. 141-218.

\section{Estkowski Ewaryst}

398. TUPAJ Maria: Ewaryst Estkowski nauczyciel, prekursor nowatorstwa pedagogicznego w XIX wieku (1820-1856). Życie Szkoty. 2001 nr 5 s. $312-313$.

\section{Hellwig Jan}

399. JAMROŻEK Wiesław: Jan Hellwig - historyk edukacji (1931-2000). Przegl. Hist.-Ośw. R. 44: $2001 \mathrm{nr} 1 / 2$ s. $97-99$.

\section{Jabłoński Pius}

400. TYRAŁA Katarzyna: Pius Jabłoński [1908-1979]. Kraków 2001 Wladysław Pilarczyk ss. 175 , nlb. 2, tabl. 6, il. Biblioteka Orawska. Nr 18.

Nauczyciel z Nowego Targu. 
Józef Sebastian Pelczar, św.

401. KRÓL Lech: Błogosławiony Józef S[ebastian] Pelczar jako wychowawca. Paedagogia Christiana. [Nr] 7: 2001 [z.] 1 s. $157-174$.

\section{Kamiński Aleksander}

402. ZAWADZKA Anna: O Aleksandrze Kamińskim „Kamyku” [1903 - 1978]. Warszawa 2001 Horyzonty ss. 181 , nlb. 2, il.

\section{Klimek Władysław Edward}

403. JANICKA Stanisława: Władysław Edward Klimek. Pedagog, działacz polityczny i animator kultury chrześcijańskiej w Gorzowie (17 II 1927 - 20 I 2000). Nadwarcianski Roczn. Hist.-Archiw. Nr 8: 2001 s. $311-315$.

\section{Konarski Stanisław}

404. ŻAK Stanisław: Ksiądz Stanisław Konarski [1700 - 1773] (pisarz - pedagog - polityk). Kielce 2001 Woj. Bibl. Publ. ss. 71.

\section{Kot Stanisław}

405. STANISŁAW Kot [1885-1975] - uczony i polityk. Pokłosie sesji naukowej. Red. nauk. Alina Fitowa. Kraków 2001 Wydaw. UJ ss. 366, tabl. 16.

Z treści: Dybiec Julian: Stanisław Kot jako historyk szkolnictwa i autor podręczników historii wychowania s. 177 - 190; Banach Andrzej Kazimierz: Działalność uniwersytecka Stanisława Kota s. 191 - 198; Ziemski Franciszek: Stanisław Kot o roli i zadaniach wychowania na studiach pedagogicznych (w świetle podręcznika: „Historia wychowania") s. 235-241.

\section{Kudelka Bolesław}

406. SADOWSKI Wojciech: Bolesław Kudelka (1884-1965). Nadwarcianiski Roczn. Hist.-Archiw. Nr 8: 2001 s. $293-294$.

Nauczyciel w liceum.

\section{Lemcke Hugo}

407. KOSMAN Janina: Działalność pedagogiczna Hugo Lemckego i dzieje Gimnazjum Mariackiego w Szczecinie. W: Hugo Lemcke [1835-1925]. Materiały z polsko-niemieckiego seminarium naukowego w Książnicy Pomorskiej, 5 grudnia 2000. Komitet red. Aleksandra Solarska [i in.]. Szczecin 2001 s. $45-60$.

\section{Małkowska Olga}

408. MAŁKOWSKA Olga: Druhna Oleńka. Zapiski. Zebrali i oprac. Olga Broniewska, Grażyna Broniewska, Jacek Broniewski; wstęp G. i J. Broniewscy. Warszawa 2000 Naczelnictwo ZHR ss. 245, nlb. 3, tabl. 8, il.

Życiorys wspóttwórczyni polskiego harcerstwa Olgi z Drohonowskich Małkowskiej (1888 - 1979) oraz jej poezje i zapiski od dzieciństwa po lata 70-te XX w. Zawiera również wspomnienie o tragicznie zmarłej O. Broniewskiej (1979-2000).

\section{Mirowski Stefan}

409. MICHAŁOWSKI Marian Ł.: Gawęda o druhu Stefanie Mirowskim [1920 - 1996]. Warszawa 2001 Horyzonty ss. 39, nlb. 1, il. Zw. Harcerstwa Pol.

\section{Moniewski Tadeusz}

410. MARCZUK Józef: Praca pedagogiczna i oświatowa Tadeusza Moniewskiego [1901 - 1939] w 100 rocznicę urodzin. Przegl. Hist.-Ośw. R. 44: $2001 \mathrm{nr}$ 1/2 s. $113-121$. 


\section{Nawka Michał}

411. JAŁMUŻNA Tadeusz: Michał Nawka [1885-1968] - pedagog i twórca powojennej szkoły lużyckiej. W: W klimacie śląskiej humanistyki. Księga jubileuszowa dedykowana Profesorowi doktorowi hab. Franciszkowi A[ntoniemu] Markowi w pięćdziesięciolecie pracy dydaktycznej i naukowej. Red. nauk. Jolanta Kwiatek, Eleonora Sapia-Drewniak. Opole 2001 s. 135 - 139.

\section{Opydo Franciszek}

412. GRAFF Tomasz: Kariery burmistrzów wadowickich. Franciszek Opydo [1856 - 1923] jako student Wydziału Lekarskiego Uniwersytetu Jagiellońskiego (1876-1881). Wadoviana. Nr 6: 2001 s. $89-93$.

\section{Pauli Martin Gottlieb}

413. MOKRZECKI Lech: Martin Gottlieb Pauli, profesor prawa i historii w Gdańskim Gimnazjum Akademickim (1753-1763). Zapiski Hist. T. 66: 2001 z. 4 s. $55-68$, Zsfg.

\section{Pawlicki Stefan}

414. GAWLIK Maciej: Ksiądz Stefan Pawlicki [1839 - 1916] jako rektor Uniwersytetu Jagiellońskiego. Zesz. Hist.-Teol. R. 7: 2001 nr 7 s. $175-192$.

Rektor w 1. $1905-1906$.

\section{Praetorius Ignacy}

415. STOLTMANN Leo: Działalność naukowa i dydaktyczna Ignacego Praetoriusa [1836-1908] w gimnazjum chojnickim. W: Polityka regionalna a historyczna i obronna świadomość Polaków. W 80. rocznicę przyłączenia Chojnic do Drugiej Rzeczypospolitej. Red. Jacek Knopek i Adam Marcinkowski. Bydgoszcz 2001 s. $60-64$.

\section{Radlińska Helena}

416. LEPALCZYK Irena: Helena Radlińska [1879-1954] - życie i twórczość. Toruń 2001 Wydaw. Adam Marszałek ss. 270, tabl. 17, il.

\section{Sitek Antoni}

417. FARON Bolesław: Mgr Antoni Sitek (1913 - 1999). Roczn. Sądecki. T. 29: 2001 s. 7 - 15. Nauczyciel, historyk-regionalista.

\section{Słomkowski Antoni}

418. KSIADZ rektor Antoni Słomkowski [1900 - 1982]. Stulecie urodzin. Materiały z sympozjum KUL, 5 grudnia 2000 r. Red. Marek Chmielewski. Lublin 2001 Red. Wydaw. KUL ss. 182, tabl. 4, il. Katol. Uniw. Lubelski. Wydz. Teologii.

Z treści: Ziólek Jan: Materialna i naukowa odnowa KUL za rektorstwa ks. prof. Antoniego Słomkowskiego s. 35 -46; Warzeszak Józef: Dar cierpienia i modlitwy ks. rektora Antoniego Slomkowskiego dla KUL s. 47-66; Malinowski Jerzy Cezary: Ksiądz Antoni Słomkowski jako rektor KUL w opinii współczesnych s. 67-91; Pylak Bolesław: Ks. prof. Antoni Słomkowski jako teolog-dogmatyk s. 93 - 104; Słomka Walerian: Wklad ks. Antoniego Slomkowskiego w polską teologię duchowości s. 105-115; Weron Eugeniusz: Moje wspomnienia o ks. Antonim Slonkowskim s. $131-142$; Karolewicz Grażyna: Moje spotkanie z ks. Antonim Slomkowskim s. 143-147; Słomkowski Antoni: Fragment wspomnié́... s. 149-150.

419. PASZKOWSKA Teresa: Ks. Rektor Antoni Słomkowski (1900-1982) odnowiciel KUL i teolog duchowości. W stulecie urodzin. Ateneum Kapt. T. 136: 2001 z. 2 s. 373-376.

Lublin, 4-5 XII $2000 \mathrm{r}$.

420. PASZKOWSKA Teresa: Sympozjum „Ks. Rektor Antoni Słomkowski (1900-1982), odnowiciel KUL i teolog duchowości - w stulecie urodzin". Roczniki Teol. T. 48: 2001 z. 5 s. $175-178$.

Lublin, 4-5 XII 2000 r. 


\section{Stanisławski Jan}

421. BEDNARSKI Tadeusz Z[ygmunt]: Jan Stanisławski [1860-1907] jako pedagog. W 140. rocznicę urodzin artysty malarza. Alma Mater. $\mathrm{Nr}$ 27: 2000/2001 [druk.:] 2001 s. $14-17$.

\section{Szaniawski Alfons Fortunat}

422. ROMANOW Piotr: „Szczęściarz” [Alfons Fortunat] Szaniawski [1837-1905]. Przegl. Polonijny. R. 27: 2001 z. 4 s. 79-94, sum.

Generał rosyjski, działacz oświatowy.

\section{Szediwy Zofia}

423. POMES Kinga, Stępień Bogdan: Zofia Szediwy (1854-1938). Prace Hist.-Archiw. T. 10: 2001 s. $213-218$.

Założycielka pierwszej biblioteki publicznej dla młodzieży w Łańcucie.

\section{Tokarz-Wisłocka Stanisława}

424. MAJERSKA Alina: Stanisława Tokarz-Wisłocka (1911 - 2000). Przegl. Bibliot. R. 69: 2001 z. $1 / 2$ s. $147-151$.

Historyk, bibliotekarz, pedagog.

\section{Wróbel Tadeusz}

425. KARCZEWSKA Joanna, Majewski Stanisław: Tadeusz Wróbel (1910-1987) życie, działalność pedagogiczna, społeczna i dorobek naukowy. Przegl. Hist.-Ośw. R. 44: $2001 \mathrm{nr}$ 1/2 s. $101-112$.

Zawiera teź bibliografię prac $\mathrm{T}$. Wróbla.

\section{Wyszyński Stefan}

426. CIEMIĘGA Katarzyna, Figiel Maciej: Związki kardynała Stefana Wyszyńskiego z ATK [Akademia Teologii Katolickiej]. W: Wspaniały to Patron... Materiały sympozjum „Dziedzictwo Kardynała Stefana Wyszyńskiego" i sesji naukowej "Spuścizna Prymasa Tysiąclecia w oczach polonisty". Warszawa, 14 kwietnia 2000. Pod red. Ewy Wolnicz-Pawowskiej. Warszawa 2001 s. $11-20$.

427. RULKA Kazimierz: Stefan Wyszyński jako alumn, profesor i rektor Włocławskiego Seminarium Duchownego. Ateneum Kapt. T. 136: 2001 z. 3 s. 416-428, rias., sum.

Lata $1917-1946$.

\section{Zienkiewicz Aleksander}

428. KSIĄDZ Aleksander Zienkiewicz [1910 - 1995] - kapłan i wychowawca. Sympozjum w piąta rocznice śmierci, Wrocław 18 - 19 listopada 2000 r. Red. Maria Chomik, Maria Lubieniecka, Jadwiga Wartalska. Kraków 2001 Bratni Zew ss. 189, nlb. 1, tabl. 4, il.

$\mathrm{Z}$ treści: Swastek Józef: Życie i duchowość księdza prałata Aleksandra Zienkiewicza na tle historii archidiecezji wrocławskiej s. 19-38; Turkowski Stanisław: Ksiadz Aleksander Zienkiewicz - wychowawca młodzieży w mojej pamięci s. 39-62; Uszyński Tadeusz: Ze wspomnień o mojej współpracy z ks. Aleksandrem Zienkiewiczem w duszpasterstwie akademickim s. 63-69; Dobierzewska-Mozrzymas Ewa: Początki działalności ks. Aleksandra Zienkiewicza wśród mlodzieży wrocławskiej s. 71 - 76.

\section{Znaniecki Florian}

429. GORISZOWSKI Włodzimierz, Kowolik Piotr: Poglady Floriana Znanieckiego [1882 - 1958] na funkcję socjologii wychowania i pedagogiki. Nauczyciel i Szkota. $2001 \mathrm{nr} 1 / 2$ s. $41-44$. 


\section{DZIEJE OŚWIATY POZASZKOLNEJ}

\section{Oświata dorosłych}

430. GREGOR Norbert F. B.: Geneza zawodowego kształcenia ustawicznego jako pochodnej kształcenia dorosłych. W: W klimacie śląskiej humanistyki. Księga jubileuszowa dedykowana Profesorowi doktorowi hab. Franciszkowi A[ntoniemu] Markowi w pięćdziesięciolecie pracy dydaktycznej i naukowej. Red. nauk. Jolanta Kwiatek, Eleonora Sapia-Drewniak. Opole 2001 s. 101 - 106.

431. INSTYTUCJONALNE formy edukacji dorosłych w Drugiej Rzeczypospolitej. Pod red. Eleonory Sapii-Drewniak i Agnieszki Stopińskiej-Pająk. Warszawa-Radom 2001 Akademickie Tow. Andragogiczne; Inst. Technologii Eksploatacji ss. 160, nlb. 1. Bibl. Edukacji Dorosłych. T. 22.

Z treści: Kabzińska Łucja: Formy i metody zwalczania analfabetyzmu wśród dorosłych $w$ działalności oświatowej Polskiej Macierzy Szkolnej w latach 1916-1939 s. 9-29; Kempa Grażyna: Rola ognisk kulturalno-oświatowych w Zagłębiu Dąbrowskim w okresie II Rzeczypospolitej w kształceniu dorosłych s. 31 - 39; Karcz Eugenia: Funkcja oświatowa Macierzy Szkolnej Slaska Cieszyńskiego w Drugiej Rzeczypospolitej s. 42-47; Aleksander Tadeusz: Działalnośé edukacyjna instytutów rzemieślniczo-przemyslowych w latach międzywojennych s. 49-67; Koźmian Danuta: Koncepcja szkoły spółdzielczej oraz jej związek z oświata dorosłych i ruchem nauczyciełskim w Polsce międzywojennej s. 69-79; Juraś-Krawczyk Barbara: Działalność Wolnej Wszechnicy Polskiej w okresie międzywojennym s. 81 - 91; Hellwig Jan: Edukacja radiowa w procesie oświaty dorosłych w okresie międzywojennym s. 93-108: Kabziński Krzysztof: Powstanie i działalność uniwersytetów ludowych Towarzystwa Czytelni Ludowych w okresie międzywojennym s. 109-120; Sapia-Drewniak Eleonora: Działalność Uniwersytetu Ludowego w Odolanowie w latach 1927-1932 s. 121-128; Stopińska-Pajak Agnieszka: Kulturalno-edukacyjna działalność świetlic w Drugiej Rzeczypospolitej s. 129-135; Półturzycki Józef: Powszechny Uniwersytet Korespondencyjny s. $137-160$.

432. KOBIETY a edukacja dorosłych. Materiały VIII Toruńskiej Konferencji Andragogicznej, 15 maja 2000. Wprow. i red. Eugenia Anna Wesołowska. Warszawa 2001 Akademickie Tow. Andragogiczne ss. 160 , nlb. 1 .

Z treści: Pótturzycki Józef: Wyższe Kursy dla Kobiet im. A. Baranieckiego s. 7-20; Tomaszewska Liliana: Problemy edukacyjne kobiet bezrobotnych w Płocku na przestrzeni 1998 i 1999 roku s. 105-112; Czajkowska Irena: Pozycja społeczna kobiet-artystek a edukacja s. 145-152.

433. PROBLEMY rozwoju ustawicznego kształcenia. W pięćdziesięciolecie Towarzystwa Wiedzy Powszechnej. Praca zbior. Pod red. Lucjana Olszewskiego. Warszawa 2001 Wydaw. WSP TWP ss. 178, mapa. Wyższa Szkoła Pedagog. Tow. Wiedzy Powszechnej w Warszawie.

434. ZYCH Edward F.: Uniwersytet Ludowy w Karpnikach w latach 1946-1949. Roczn. Jeleniogórski. T. 33: 2001 s. $123-130$.

\section{Biblioteki}

435. ANDRZEJEWSKA Jadwiga: Udział bibliotekarzy bibliotek szkolnych i pedagogicznych w działalności Stowarzyszenia Bibliotekarzy Polskich (1917-2000). Roczniki Bibliot. R. 45: 2001 s. $227-254$, sum.

436. WAŁEK Bożena: Szkolne biblioteki okręgowe w Galicji doby autonomicznej w procesie kształcenia i doskonalenia nauczycieli szkół ludowych. W: Kraków - Lwów. Książki, czasopisma, biblioteki XIX i XX wieku. T. 5. Pod red. Jerzego Jarowieckiego. Kraków 2001 s. 213-224.

437. WÓJCIK Małgorzata: Biblioteka Towarzystwa Szkoły Ludowej w Rzeszowie (1906 - 1914). Prace Hist.Archiw. T. 10: 2001 s. 219-231. 


\section{DZIEJE RUCHU NAUCZYCIELSKIEGO}

\section{Opracowania ogólne}

438. GRZEŚ Bolesław: Związki nauczycielskie a reformowanie szkolnictwa na ziemiach polskich w XX w. (Cz. 1). Przegl. Hist.-Ośw. R. 44: 2001 nr 1/2 s. $15-38$.

439. KACZOR Stanisław: Stowarzyszenie Oświatowców Polskich. Zarys monograficzny na XX-lecie działalności. Warszawa-Toruń 2001 SOP ss. 256, il. Stow. Oświatowców Pol.

440. MICHALSKI Grzegorz: Działalność Stowarzyszenia Chrześcijańsko-Narodowego Nauczycielstwa Szkół Powszechnych 1921 - 1939. Łódź 2001 Wydaw. UŁ ss. 291. Rozprawy Habilitacyjne Uniwersytetu Łódzkiego.

\section{Pamiętniki nauczycieli}

441. GAKLIK Maria: Pamiętnik nauczycielki. Oprac. Monika Kała. Biul. Inst. Pamięci Nar. Nr 7: 2001 s. $63-72$.

Dziennik lwowskiej nauczycielki (12 X 1939 - 11 IX 1940).

442. HENSEL Witold: Wyrwane kartki z pamiętnika - dwukrotny szczęśliwy los w listopadzic 1944 r. Slavia Antiqua. T. 42: 2001 s. $187-190$.

O poczatkach pracy w KUL.

443. HURWIC Józef: Z Politechniki Warszawskiej na uniwersytet w Marsylii. Roczniki [Stacja Nauk. PAN w Paryżu]. T. 4: 2001 s. $181-190$.

Wspomnienia profesora chemii z lat 1957-2000.

444. KOSEK Karol: Dialektyczni władcy. Ząbki 2001 Apostolicum ss. 229, nlb. 2.

Pamiętnik nauczyciela z lat $1956-1989$.

445. LATOS Zdzisław: Wspomnienia wiejskiego nauczyciela. Krosno 2001 Apla ss. 76, il. Szkoły w Błažku, Batorzu i Urzędowie w I. 1951-1972.

446. MISZTAL Irena (Piotuch Tamara): Takie sobie dzieje. Ełk 1999 Nakł. autorki ss. 55.

Cz. 2: Międzywojnie. Oprac. i red. Eugeniusz Kurzawa. Ełk 2000 ss. 51.

Cz. 3: Dwie okupacje. Wstęp E. Kurzawa. Elk 2001 ss. 71.

Wspomnienia nauczycielki ur. w 1908 r. z nauki w seminarium nauczycielskim w Grodnie i pracy pedagogicznej na Grodzieńszczyźnie.

447. NARUSZEWICZ Władysław: Wspomnienia lidzianina. Warszawa 2001 Bellona ss. 304, tabl. 44, mapy.

M.in. wspomnienia o Szkole Powszechnej i Szkole Handlowej im. Konarskiego w Kolegium Ojców Pijarów w Lidzie z 1. 1928 - 1938.

448. OLĘDER Stanisław: W Szkole Spółdzielczo-Handlowej w Kozienicach. Wieś Radomska.

[T.] 6: 2001 s. $277-286$.

Wspomnienia z 1. 1929 - 1938.

449. PALM Melania: Widziane ze schronu. Częstochowa 2001 Tygodnik Katol. „Niedziela” ss. 187, nlb. 2, il. Biblioteka „Niedzieli”. T. 125. Świadkowie. T. 2.

Dziennik szarytki, wychowawczyni w internacie szkolnym na warszawskim Żoliborzu 30 VII - 3 X $1944 \mathrm{r}$.

450. PIOTROWSKI Stefan: Dziennik nauczyciela szkoły średniej z 1945 roku. [Wyd.] Bartłomiej

Szyndler. Biuletyn [Inst. Filoz.-Hist. WSP w Częstochowie]. [Nr] 28: 2001 s. 17-23.

Styczeń-marzec $1945 \mathrm{r}$.

451. PROSZE do tablicy. Wspomnienia ustrońskich nauczycieli i uczniów. Oprac. Danuta Koenig

[i in.]. Ustroń 2001 Muzeum Hutnictwa i Kuźnictwa ss. 103, nlb. 5. 
452. SZNAJDER Piotr: Wspomnienia nauczyciela Szkoły Rolniczej w Zwoleniu. Oprac. Przemysław i Stanisław Zielińscy. Wieś Radomska. [T.] 6: 2001 s. 259-276.

Z 1. $1934-1939$.

453. SZURKOWSKA Olga: Dzieje białowieskiej rodziny. Białowieża 2001 Nakł. aut.; Fotoskład Komputerowy ss. 160, tabl. 16, il.

Wspomnienia nauczycielki urodzonej w $1931 \mathrm{r}$. w rodzinie zamożnego białoruskiego chłopa z dzieciństwa w rodzinnej wsi Podolany w środku Puszczy Białowieskiej, ze szkolnych lat w Hajnówce oraz ze studiów w Warszawie.

454. UZIAK Stanisław: Pól wieku w Uniwersytecie Marii Curie-Skłodowskiej. Cz. 1 - 2. Lublin 2001 Wydaw. Uniw. Marii Curie-Skłodowskiej ss. 238, nlb. 1, tabl. 11; 366, tabl. 2.

\section{ORGANIZACJE MŁODZIEŻOWE}

455. ABRAMOWICZ Sławomir: Młodzieżowe organizacje antykomunistyczne $w$ centralnej Polsce w latach 1945-1955. Biul. Inst. Pamięci Nar. Nr 3: 2001 s. 30-42.

$\mathrm{W}$ aneksie wykaz organizacji.

456. ANDRYKIEWICZ Jan: Zwiazek Młodzieży Wiejskiej w latach 1957-1976. Wyd. 2 popr. Warszawa 2001 MHPRL ss. 117, nlb. 1. Muzeum Historii Pol. Ruchu Lud., Zakł. Historii Pol. Ruchu Lud. NKW PSL.

457. BARAN Adam F.: Harcerska alternatywa. ZHR w latach 1989-1990. Warszawa 2000 Naczelnictwo ZHR ss. 215, tabl. 12.

458. BONDARYK Krzysztof: Niezależne Zrzeszenie Studentów w Białymstoku w latach 1980 - 1981. Wyd. 2. Warszawa 2001 Akces ss. 111, il.

Wyd. 1. Białystok 1999.

459. CZYLOK Tadeusz: Z ich krwi i męczeństwa nasza wolność. Katowiccy harcerze lat wojny. Katowice 2001 Komenda Hufca ZHP im. Bohaterów Wieży Spadochronowej ss. 332, il.

460. DROZDEK-MALOLEPSZA Teresa: Działalność Towarzystw Gimnastycznych „Sokół” w Radomsku i w powiecie radomszczańskim w latach 1921-1939. Prace Nauk. [WSP w Częstochowie]. Kultura Fizyczna. Z. 4: 2001 s. 9 -39, sum.

461. DRUGA konspiracja niepodległościowa. Tajne organizacje młodzieży szkolnej Lublina i Lubelszczyzny w latach 1945 - 1956. Oprac. Jan Ziółek. Przy współudziale Anny Gronek i Małgorzaty Walczak. Lublin 2001 Tow. Nauk. Katol. Uniw. Lubelskiego ss. 313, nlb. 2.

Z treści: Gosiewski Janusz: Z dziejów niepodległościowego ruchu oporu w Nałęczowie s. 165-172; Kowalik Krystyna: Aresztowanie i przebieg śledztwa s. 173-180; Łokaj Jan: Orlęta s. 181 -190; Ostrowski Czesław: Przebieg wydarzeń zwiazanych z aresztowaniem i więzieniem s. 191 - 195; Rak Jerzy: Moje przeżycia w latach 1952-1953 s. 196 - 201; Śliwczyński Roman: Młodzieżowa Organizacja Niepodleglościowa w Więzieniu Progresywnym Jaworzno s. 237 - 242; Biogramy bylych więźniów politycznych s. 245 - 269; Wykaz nazwisk i pseudonimów czlonków tajnych organizacji s. 273-277; Wykazy sędziów, prokuratorów, lawników Wojskowego Sadu Rejonowego w Lublinie, którzy skazywali członków młodzieżowych organizacji niepodległościowych w Lublinie s. 278-284.

462. FLORKOWSKI Henryk: Drużyna harcerska im. generała Dezyderego Chłapowskiego w Turwi (1926-1928). Pamiętn. Tow. Mitośn. Ziemi Kościańskiej. [T. 10]: 1996 - 2000 [druk.:] 2001 s. $70-74$.

463. HARCERSTWO poleskie. Brześć-Kobryń. Materiały zebrała i oprac. Helena Arciszewska-Jakubowska. Zabki 2001 Apostolicum ss. 183, nlb. 1, tabl. 8, il.

Z treści: Arciszewska-Jakubowska H.: Wstęp s. 9- 16; Taż: Krahelska Krystyna s. 23 - 46; Rak-Stępień Henryka: Harcerstwo na Kresach Wschodnich II Rzeczypospolitej, Polesie s. 47-56; Taż: Załuski Stefan Leszek s. 57-60; 
Arciszewska-Jakubowska H.: Zarzycki Ryszard s. 61-67; Klajn Krystyna: Działalność w Harcerstwie Żeńskim w latach przedwojennych i wojennych s. 69-74; Arciszewska-Jakubowska H.: Piechowicz Aleksandra s. 75-76; Wilczyńska-Simon Marta: Krótkie wspomnienia s. 77-78; Arciszewska-Jakubowska H.: [Wspomnienia] s. 79 -88; Wirkus Kazimiera: Wspomnienia harcerki s. 89-92; Szwarcówna-Samborska Wanda: Relacja z pobytu w Kazachstanie s. 93-96; Bemówna Irena: Relacja z pobytu w Kazachstanie s. 97-106; Odyńska-Zarzycka Natalia: Moje wspomnienia z działalności harcerskiej podczas okupacji niemieckiej s. 107-113; Odyński Jeremi: Krótki życiorys s. 115-120; Pjetraszkjewicz Stefan: Harcerskie wspomnienia s. 121-136; Ryżko Stanisław: Harcerstwo w Seminarium Duchownym w Pińsku s. $137-144$; Komorowski Jan: [Relacja] s. 145-148; Jagielio Wladysław: Fragmenty pamiętnika dotyczace harcerstwa s. 149-154; Jagiełło Stanisław: [Życiorys] s. 155-156; Jagiełlo Zdzisław: Byłem harcerzem na Polesiu (1935-1939) s. 157-174; Prawo Harcerskie z 1920 r. s. $175-176$.

464. KAMIŃSKI Aleksander, pseud. Juliusz Górecki: Wielka gra. Oprac. Andrzej Krzysztof Kunert; przedm. Stanisław Broniewski. Warszawa 2000 Rytm ss. 331, nlb. 1, tabl. 22, il.

Związek Harcerstwa Polskiego w I. 1939-1945.

465. KAMOCKI Janusz: Wspomnienia harcerskie z sandomierskich lat. Zesz. Sandomierskie. R. 8: $2001 \mathrm{nr} 13$ s. 53.

Z 1. $1944-1946$.

466. KATAFIASZ Tomasz: Harcerstwo pomorskie w walce o niepodległość i granice Rzeczypospolitej 1911 - 1921 ( $z$ uwzględnieniem środowiska chojnickiego). W: Polityka regionalna a historyczna i obronna świadomość Polaków. W 80. rocznicę przyłączenia Chojnic do Drugiej Rzeczypospolitej. Red. Jacek Knopek i Adam Marcinkowski. Bydgoszcz 2001 s. 65-86.

467. KAZBERUK Wiesław: Dramatyczne i humorystyczne momenty z pokazowego procesu Harcerskiej Organizacji Podziemnej (HOP) „Iskra”. Borussia. Nr 20/21: 2000 s. 159- 164.

Uzup.: Baranowski Klemens, Tamze s. $164-165$.

Wspomnienia o olsztyńskim procesie w dniach $22 \mathrm{~V}-5$ VI $1950 \mathrm{r}$.

468. KOMOROWSKI Jerzy: Niepokornych „Droga do Orłów”. Siedemdziesią lat krakowskiej "dziewiętnastki". Kraków 2001 Zw. Harcerstwa Rzeczypospolitej. Szczep 19 Krakowskich Drużyn Lotniczych im. F. Żwirki i S. Wigury 4 ss. 223, nlb. 1, tabl. 8.

469. KREŻ̇L Janusz: 90 lat skautingu - harcerstwa w Mielcu, 1911-2001. Roczn. Mielecki. T. 4: 2001 s. $69-99$.

470. KSIEGGA pamiatkowa 25-lecia harcerstwa w Lubelszczyźnie. Wspomnienia i dokumenty 1911 - 1936. Oprac. Tadeusz Moniewski przy współudziale komitetu red. R. Błeszczyńska [i in.]. Lublin 2001 Woj. i Miej. Bibl. Publ. im. Hieronima Łopacińskiego ss. 193, nlb. 1, tabl. 16.

471. KUŹNIA Teresa: Historia Hufca ZHP im. Grzegorza Piramowicza w Międzyrzecu Podlaskim. Roczn. Międzyrzecki. T. 31/32: 2001 s. 289-321.

Lata 1975 - 1993.

472. LEONHARD Bolesław: Kalendarium z dziejów harcerstwa krakowskiego 1910 - 1950. Wyd. 2. Kraków 2001 Tow. Sympatyków Historii ss. 255, tabl. 16.

Wyd. 1. 1984.

473. ŁYSAKOWSKI Roman: Z dziejów Żeglarskiej Drużyny Harcerskiej w Bialej Podlaskiej (1944-1946). Podlaski Kwart. Kult. 2001 nr 2 s. 41 - 54.

474. MAŁKOWSKI Kazimierz, Twardowski Marek, Paciorek Piotr. Gdyńska Drużyna Harcerzy im. Bolesława Chrobrego 1931 - 1994. Pod red. M. Twardowskiego. Gdańsk 2001 Wydaw. JSC ss. 84, tabl. 54, il.

475. MAŁOLEPSZA Agata: Począti harcerstwa w Kłobucku. Biuletyn [Inst. Filoz.-Hist. WSP w Częstochowie]. [Nr] 28: 2001 s. $150-161$.

Od 1917 r. 
476. MATEJKO Pawel: Polskie Towarzystwo Gimnastyczne „Sokół” gniazda: Jordanów, Sucha, Maków. Zarys historii i działalności. Sucha Beskidzka-Kraków 2001 Księg. Matejko; Wydaw. Zakonu Pijarów ss. 187, tabl. 16, il.

$\mathrm{XIX}-\mathrm{XX}$ w.

477. MATEUSZEWSKA Lidia: Harcerz $\mathrm{z}$ pięciolinia czyli Moja przygoda $\mathrm{z}$ CZA ZHP [Centranym Zespołem Artystycznym Związku Harcerstwa Polskiego]. Warszawa 2000 Stow. Wychowanków im. Władysława Skoraczewskiego ss. 114, il.

Pamiętnik.

478. MAZURKIEWICZ Mirosław: Jeszcze nie zgasły ogniska. Gawędy o harcerstwie Choragwi Radomskiej. Radom 2001 Społ. Komitet Ratowania Zabytków Radomia ss. 198, il.

$\mathrm{XX}$ w.

479. NIEMIER Renata: Związek Młodzieży Wiejskiej Rzeczypospolitej Polskiej „Wici” (w 70. rocznice powstania). Roczn. Muzeum Nar. Rolnictwa w Szreniawie. T. 22: 2001 s. 207-214.

480. NOWAKOWSKI Tadeusz: Dzieje skautingu i harcerstwa w Piotrkowie Trybunalskim w latach 1911 - 1939. Red. Marcin Gasior. Piotrków Trybunalski 2001 Tow. Przyj. Miasta Piotrkowa Trybunalskiego; Muzeum ss. 80, il. Biblioteka Piotrkowska. Nr 20.

481. OLSTOWSKI Przemysław: PET i Organizacja Młodzieży Narodowej w Częstochowie w latach 1904 - 1914. Przyczynek do dziejów ruchu zetowego w Królestwie Polskim przed I wojną światowa. Czasy Nowożytne. T. 10: 2001 s. $119-146$.

482. ORGANIZACJA Bojowo-Dywersyjna Młodzieży Polskiej „Orlęta”. [Wyd.] Igor Hałagida, Piotr Semków. Biul. Inst. Pamięci Nar. Nr 5: 2001 s. 48-51.

Dokumenty z 1948 r. antykomunistycznej organizacji z Gdyni.

483. PAWLUCZUK Zdzisław: Towarzystwo Gimnastyczne „Sokół” na południowym Podlasiu w latach 1906-1931. Podlaski Kwart. Kult. 2001 nr 1 s. 5-29.

484. PESKA Roman: W zdrowym ciele zdrowy duch. Z dziejów Towarzystwa Gimnastycznego „Sokół” w Pabianicach 1906-2000. Pabianice 2001 Pamięć ss. 110, tabl. 14, il.

485. POLAK Wojciech: Najtrudniejsze egzaminy. Niezależne Zrzeszenie Studentów Uniwersytetu Mikołaja Kopernika na tle wydarzeń w kraju i regionie (1980-1982). Toruń 2001 Wydaw. Uniw. M. Kopernika ss. 454 , nlb. 2, tabl. 104, il., sum.

486. RUCH młodowiejski na Żywiecczyźnie w latach 1912 - 1972. Praca zbiorowa. Pod red. Jana Janika i Antoniego Urbańca. Żywiec 2001 Przedsiębiorstwo Handlowe „Ge-Es” ss. 224, il.

Z treści: Janik Jan: Początki ruchu młodzieży wiejskiej na Żywiecczyźnie [lata 1928-1957] s. 6-61; Urbaniec Antoni: Związek Młodzieży Wiejskiej na Żywiecczyźnie w latach 1957-1972 s. 62-134; Rączka Antoni: ZM ZMW to była wspaniała szkoła życia s. 135 - 143; Słonka Zofia: Wspomnienia sekretarza powiatowej Rady PR s. 144 - 149; Trębacz Tadeusz: Tak się trudno rozstać s. 150 - 166; Deptuła Marian: Ludowe zespoły sportowe na tle życia sportowego na Żywiecczyźnie s. 167 - 177; Fułat Mieczysław: Moje wspomnienia z działalności kulturalno-oświatowej s. 178 - 187; Stanik Czesław: Początki działalności sportowej w Ślemieniu s. 188 - 196; Kantyka Feliks: Narodziny klubu s. 197 - 202; Duraj Maria: Jestem dzieckiem wsi s. 203 - 204; Klimczak Zygmunt: Pierwszy był Zwiazek Młodzieży Wiejskiej s. 205- 207.

487. SAJAK Andrzej, Wojtycza Janusz: Towarzystwo Gimnastyczno-Strzeleckie „Sokół” w Bochni w latach 1891 -1914. Roczn. Bocheński. T. 5: 2001 s. 157-185.

488. SUCHARSKA Dorota: W zielone chusty przystrojeni. Dzieje Szczepu Siódmych Bydgoskich Drużyn Harcerskich w Bydgoszczy im. Hetmana Jana Karola Chodkiewicza w latach 1921-2001. Bydgoszcz 2001 Margrafsen ss. 163, nlb. 1, tabl. 20, il., mapa.

489. WACHOWICZ Barbara: Druhno Oleńko! Druhu Andrzeju! Gawęda o twórcach Harcerstwa Polskiego Oldze [1888 - 1979] i Andrzeju [1888 - 1919] Małkowskich. Wyd. 2 uzup. Warszawa 2000 Rytm ss. 273, nlb. 7, il. Wierna Rzeka Harcerstwa. [T.] 1.

Wyd. 1. 1995. 
490. WIECHEĆ Aleksander: Dzieje gniazd sokolich w obecnym powiecie suskim. Wadowice 2001 Grafikon ss. 176, il.

$\mathrm{XIX}-\mathrm{XX}$ w.

491. WILCZYŃSKI Leszek: Katolickie organizacje młodzieży męskiej w Wielkopolsce 1860 - 1939. Torú 2001 Wydaw. Adam Marszalek ss. 251, il., mapy.

492. WISZKA Emilian: „Dancigerzy” - działalność ukraińskich organizacji studenckich na Politechnice Gdańskiej w latach 1922 -1933. Roczn. Gdański. T. 60: 2000 z. 1 s. 63-70, sum.

493. WIŚNIEWSKA Halina Maria: Gawędy druhny Babci. Warszawa 2001 Horyzonty ss. 263, il.

Dzieje harcerstwa, $X X$ w.

494. WIŚNIEWSKA Małgorzata: Idee wychowania obronnego młodzieży w koncepcji i praktycznej działalności organizacji „Strzelec” w latach 1921-1939. W: Polityka regionalna a historyczna i obronna świadomość Polaków. W 80. rocznicę przyłączenia Chojnic do Drugiej Rzeczypospolitej. Red. Jacek Knopek i Adam Marcinkowski. Bydgoszcz 2001 s. 411-418.

495. WYBRANE zagadnienia z organizacji i historii Akademickiego Związku Sportowego. Na 55-lecie AZS w Częstochowie (1945-2000). Praca zbior. pod red. Andrzeja Nowakowskiego. Częstochowa 2001 Częstochowskie Wydaw. Nauk. przy Wyższej Szkole Zarzadzania ss. 196.

496. Z DZIEJów kultury fizycznej w Polsce i wśród Polaków na obczyźnie w latach 1918 - 1939. Pod red. Eligiusza Małolepszego i Mirosława Ponczka. Częstochowa 2001 Wydaw. Wyższej Szkoły Pedagog. ss. 119, sum.

Z treści: Kalamacka Ewa: YMCA w Polsce i Polska YMCA (1919-1939) s. 15 -25; Nowakowski Andrzej: Dzieje i działalność gniazda ",Sokola” w Suchej Beskidzkiej w okresie międzywojennym s. 27 - 35; Ponczek Mirosław Ksiadz Tadeusz Jachimowski (1892 - 1944) - Naczelny Kapelan Sokolstwa Polskiego w II Rzeczypospolitej s. 37 - 46.

497. Z DZIEJÓw organizacji studenckich na lwowskich wyższych uczelniach w II Rzeczypospolitej. Oprac. Grzegorz Mazur i Adrian Tyszkiewicz. Zesz. Hist. Z. 137: 2001 s. 95-116.

Dwa dokumenty $z$ końca lat 30-tych odnalezione w zespole akt starostwa grodzkiego we Lwowie, obrazujace działalność, skład władz i liczebność organizacji studenckich.

498. Z KIM w XXI wiek. Księga Drużyn Grunwaldzkich wydana w X rocznice powstania „Wspólnoty”. Red. Barbara Bogdańska-Pawłowska, Henryk Leśniowski. Olsztyn $2001 \mathrm{KCW}-\mathrm{M}$ ZHP ss. 321, nlb. 6, tabl. 2, il. Zw. Harcerstwa Pol. Ogólnopol. Ruch Metodyczno-Programowy „Wspólnota Drużyn Grunwaldzkich” przy Komendzie Choragwi Warmińsko-Mazurskiej im. „Grunwaldu”.

499. ZARYS dziejów Sokolstwa Polskiego w latach 1867-1997. Praca pod red. Eligiusza Małolepszego i Zdzisława Pawluczuka. Częstochowa 2001 Wydaw. WSP ss. 298, nlb. 1, il., sum. Wyższa Szkoła Pedagog. w Częstochowie.

Treść: Rozdz. I. Sokolstwo polskie w latach 1867-1918: Toporowicz Kazimierz: Geneza Towarzystwa Gimnastycznego "Sokót” na ziemiach polskich. Powstanie "Sokoła” we Lwowie s. 9-13; Snopko Jan, Dudek Dobiesław: Rozwój ruchu sokolego w zaborze austriackim s. 13-29; Woltmann Bernard: „Sokół” na terenach zaboru pruskiego i w Niemczech (1884-1918) s. 29-41; Ponczek Mirosław: „Sokót” w Królestwie Polskim i w Rosji (1888-1918) s. 41 - 47; Szczerbiński Marek, Pawluczuk Z.: „Sokól” na zachodzie Europy (Francja, Belgia i Holandia) s. 47 - 54: Radzik Tadeusz, Szczerbiński M.: „Sokó'” na kontynentach amerykańskich (1887-1918) s. 54 - 62; Rozdz. II. „Sokół” w II Rzeczypospolitej i w Wolnym Mieście Gdańsku w latach 1919-1939: Drozdek-Małolepsza Teresa: Powstanie Zwiazku Towarzystw Gimnastycznych "Sokół” w Polsce s. 63-69: Nowakowski Andrzej: Podstawy prawno-organizacyjne Zwiazku Towarzystw Gimnastycznych "Sokót” w Polsce s. 69-84; Drozdek-Małolepsza T.: Udział kobiet s. 84-90; Taż: Rozwój liczebny i skład socjalny członków s. 90-93; Marciszewska Barbara: Baza materialna działalności sokolej s. 93 - 99; Małolepszy E.: Wychowanie fizyczne, oświatowe i prasowo-wydawnicze s. 99 - 133; Stryjkowski Krzysztof: Działalność kulturalna, oświatowa i prasowo-wydawnicza s. 133 - 150; Pawluczuk Z: Oblicze polityczne s. 150-157; Tenże: „Sokół” w Wolnym Mieście Gdańsku s. $157-163$; Rozdz. III. Sokolstwo polskie na obczyźnie w latach 1919-1939: Pawluczuk Z., Szczerbiński M.: Podstawy ruchu sokolego w środowiskach polonijnych s. 164-168; Woltmann B.: „Sokót” polski w Niemczech s. 168 - 175; Szczerbiński M., Małolepszy E. Zwiazek Sokolstwa Polskiego we Francji, Belgii i Holandii s. 176-179; Gasiorowski Andrzej: Ruch sokoli w Europie południowo-wschodniej s. 179-186; Radzik T., Szczerbiński M.: Zwiazek Sokolstwa Polskiego w Stanach 
Zjednoczonych Ameryki Północnej s. 186 - 189; Pawluczuk Z., Szczerbiński M.: Wzajemne związki polonijnego ruchu sokolego z Macierza s. 189 - 193; Rozdz. IV. Sokolstwo polskie w czasie Il wojny światowej (1939-1945): Gizowski Mariusz: „Sokót" na terenach okupowanej Polski s. 194-198; Pawluczuk Z.: Związek Sokołów Polskich w Stanach Zjednoczonych Ameryki Północnej s. 198-199; Rozdz. V. Sokolstwo polskie po Il wojnie światowej (1945 - 1997): Bujanowski Zdzisław, Ponczek M., Łopata Andrzej: Działalność Towarzystwa Gimnastycznego „Sokót” w Polsce po II wojnie światowej s. 200-213; Pawluczuk Z.: "Sokól”" w Stanach Zjednoczonych AP s. 213-219; Gogolewski Edmond: ",Sokól” we Francji, Belgii i Holandii s. 219-227; Hładkiewicz Wiesław: „Sokól” w Niemczech s. 227 - 232; Pawluczuk Z.: „Sokól” w Wielkiej Brytanii s. 232 - 240; Rozdz. VI: Gizowski M.: Symbolika sokolstwa s. 241 - 246; Tenże: Aneksy s. $255-263$.

500. ZAWADZKA Anna: Gawędy o tych które przewodzily. Cz. 1: Olga Małkowska, Jadwiga Falkowska, Józefina Łapińska, Jadwiga Zwolakowska. Warszawa 2001 Horyzonty ss. 293, nlb. 3.

501. ZAWIŚLAK Władysław: Wielka próba. Wspomnienia więzienne 1946 - 1949. Wstęp Tomasz Gąsowski; przedm. Wojciech Hauser. Kraków 200I Fundacja CDCN; Księg. Akademicka ss. 134, nlb. 1, tabl. 8, il. Biblioteka Centrum Dokumentacji Czynu Niepodległościowego. T. 16.

Wspomnienia kierownika konspiracyjnej organizacji harcerskiej kryptonim Polska Straż Przednia o aresztowaniu przez UB i śledztwie przy Placu Inwalidów oraz pobycje w więzieniach w Krakowie i w Rawiczu.

502. ZLELECKI Alojzy: Zaranie polskiego ruchu młodzieżowego w Galicji. W: Działalność wyzwoleńcza. Red. Jadwiga Hoff. Rzeszów 2001 s. 200 - 222.

503. ŻEBROWSKI Rafal: Żydowska organizacja skautowa Ha-Noar ha-Cijoni i jej muszyńskie gniazdo. Almanach Muszyny. [R. 11]: 2001 s. $121-127$.

Lata 1928 - 1934.

504. ŻYCHOWSKA Maria: Konspiracyjne organizacje młodzieżowe w tarnowskiem $w$ latach 1945 - 1956. Tarnów 2001 Tarnowskie Tow. Kult. ss. 519.

Opracowata Anna Gruca 